Portland State University

PDXScholar

$1-1-2013$

\title{
Portland, Oregon's Long Hot Summers: Racial Unrest and Public Response, 1967-1969
}

Joshua Joe Bryan

Portland State University

Follow this and additional works at: https://pdxscholar.library.pdx.edu/open_access_etds

Part of the Public History Commons, Social History Commons, and the United States History Commons

Let us know how access to this document benefits you.

\section{Recommended Citation}

Bryan, Joshua Joe, "Portland, Oregon's Long Hot Summers: Racial Unrest and Public Response, 1967-1969" (2013). Dissertations and Theses. Paper 995.

https://doi.org/10.15760/etd.995

This Thesis is brought to you for free and open access. It has been accepted for inclusion in Dissertations and Theses by an authorized administrator of PDXScholar. Please contact us if we can make this document more accessible: pdxscholar@pdx.edu. 
Portland, Oregon's Long Hot Summers:

Racial Unrest and Public Response, 1967 - 1969

\author{
by \\ Joshua Joe Bryan
}

A thesis submitted in partial fulfillment of the

Requirements for the degree of

Master of Arts

in

History

Thesis Committee:

David A. Horowitz, Chair

Victoria C. Belco

Patricia A. Schechter

Randy Blazak

Portland State University

2013 


\begin{abstract}
The struggles for racial equality throughout northern cities during the late1960s, while not nearly as prevalent within historical scholarship as those pertaining to the Deep South, have left an indelible mark on both the individuals and communities involved. Historians have until recently thought of the civil rights movement in the north as a violent betrayal of Dr. Martin Luther King, Jr.'s vision of an inclusive and integrated society, as well as coinciding with the rise, and subsequent decline, of Black Power. But despite such suppositions, the experiences of northern cities immersed in the civil rights struggle were far more varied and nuanced.
\end{abstract}

The explosion of racial violence throughout American cities in the late-1960s bred fear among many in the white political establishment who viewed the cultural shifts inherent in racial equality as threatening to undermine their traditional racial dominance. Partially the result of feelings of increased powerlessness, and partially in an effort of self-preservation, many in the ranks of government and law enforcement worked to oppose the seismic changes underfoot. This thesis makes a concerted effort to examine and evaluate the role that race played in the Albina community of Portland, Oregon in the late-1960s, with a particular emphasis on the motivations, impact, and legacy of two racial disturbances that occurred there in the summers of 1967 and 1969. It asserts that while racial prejudice and bigotry were certainly prevalent among members of both the city's political and law enforcement community, and did play a significant role in the deterioration of their relationship with the black community, there were many other factors that also contributed to 
the police-community discord in late-1960s Albina. Moreover, it asserts that the reactions of the white and African-American communities to the disturbances were, contrary to conventional wisdom, not monolithic, but rather diverse and wideranging.

The goal of this narrative history is not merely to analyze the racial unrest and public response to the disturbances, but also to integrate and link the experiences of Portland's African-Americans into the broader dialogue of the civil rights movement of the late-1960s. In short, the study of late-1960s Portland allows us to reach a greater understanding of racial inequality in America during this period. 


\section{Acknowledgments}

Over the course of the three years in which I've researched and written this thesis, I have incurred many debts that I can never repay. As such, I offer the following thanks as a tiny gesture of recognition for the kindness and patience that friends, family, and faculty have shown me.

This thesis would certainly be very different were it not for my cohort of fellow M.A. students, whose conversations and friendship sustained me for much of the past three years. The kind words and challenging questions they offered early on in the process provided motivation for me when I crucially needed it. A humble thanks must also be extended to Will Thompson who, when I wondered if this thesis would ever actually be completed, offered his own time, advice, and encouragement.

A special thanks to my family - to my brother, Ben, my sister, Laura Jo, and especially to my mother, Patricia Bryan, for supporting me emotionally and financially on this journey. No small token of appreciation must also be extended to Dave, Joni, and Eric Edison. Thank you for the constant support, as well as your willingness to feign interest in all things historical. And my wife, Lauren - although she hardly needs thanking, so essential is she to everything good in my life - I thank wholeheartedly. I am indebted to you numerous times over.

Professors and Instructors at Oregon State University challenged and supported me and I have greatly benefitted from their steadfast devotion to their students. Joseph Orosco, Jonathan Katz, Amy Leer, Paul Wanke, and especially Mike O'Malley made me believe that graduate school was possible. I have also been 
fortunate to study with the faculty of Portland State University's history department. In my three years as a graduate history student at Portland State, I have learned a great deal and pursued many opportunities I might not have otherwise pursued without their encouragement.

I extend my gratitude to my adviser, David A. Horowitz, with whom I have worked for the last three years. I am truly grateful for his wisdom, persistence, and generosity with his time, as well as his unwavering encouragement during my own moments of flagging inspiration. This thesis would not have come about without his flexibility and guidance.

A sincere thank-you to other PSU faculty as well: Darrell Milner of the Black Studies department, who was invaluable and willing to dispense with historical knowledge concerning the African-American experience in Oregon, and who was, without hesitation, willing to assist with any contextual help I needed during the process; Cris Paschild, PSU archivist, who worked tirelessly to assist with any relevant sources related to my own thesis topic; and Jeff Brown, History department secretary, to whom all bureaucratic progress within the department is owed.

Finally, I want to thank Victoria Belco, Patricia Schechter, and Randy Blazak for volunteering to serve on my thesis committee. The work that follows profited from their insights. 


\section{Contents}

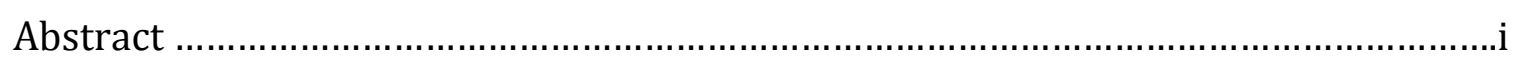

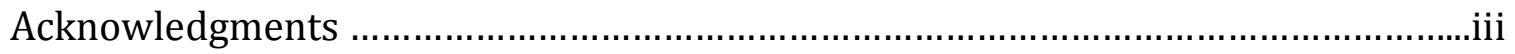

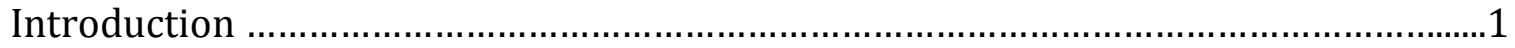

Chapter One

The Disturbances at Irving Park (1967) ..................................................16

Chapter Two

Public Response to the Irvin Park Disturbances (1967) ...............................36

Chapter Three

Changing the Status Quo (1968) ...........................................................54

Chapter Four

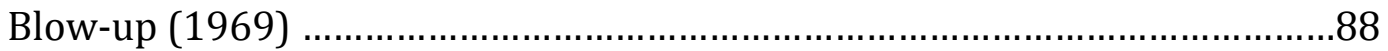

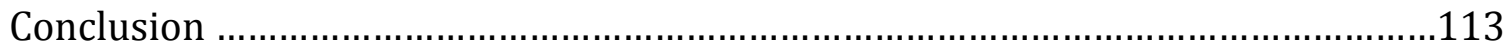

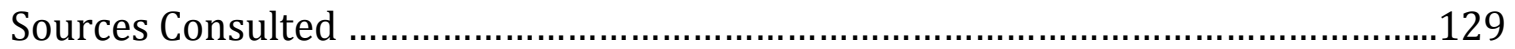

Appendix A

Map of the Albina Neighborhood.........................................................141 


\section{Introduction}

On May 24, 1969, a nineteen-year-old African-American named Percy Hampton was arrested at the intersection of N.E. Going Street and Cleveland Avenue, in the northeast section of Portland, Oregon, on charges of disorderly conduct, resisting arrest, and assault. A young leader within Portland's black community, Hampton had been at home only a couple blocks away from the intersection moments earlier when, after a commotion outside, a neighbor running by the house told him that his younger brother was being beaten by local police officers. As he sprinted to the intersection in an effort to come to his brother's aid, Hampton was ordered to "stop" by two policemen shouting behind him. Responding that it was his brother that was being assaulted by the officers, Hampton refused the directive and moved closer towards the altercation until a nearby police car intercepted him. ${ }^{1}$ What occurred next is disputed.

According to Hampton, four police officers, without provocation, jumped out of the police car and pinned him against a nearby wall. Cuffing and kicking him, they threw him into the patrol car and arrested him. ${ }^{2}$ The narrative of the same altercation by Portland police, however, differed greatly. Disputing the assertion that any use of force had been unprovoked, the police stated that Hampton had become "abusive" shortly after they had confronted him, and that a crowd of nearly one-hundred and fifty individuals, many of whom were spitting and striking the police as the arrest proceeded, had created an overtly hostile atmosphere. ${ }^{3}$ 
As Hampton recounted that year, the episode of May 1969 served as the first of three altercations he eventually had with Portland police over the course of three weeks, with each arrest preceded by physical abuse. ${ }^{4}$ Clashes between members of the city's African-American community and the police, while certainly not routine, had become much more frequent by the time of Hampton's initial encounter. Although many issues such as low-quality and overcrowded housing, soaring unemployment, poverty, and de facto segregation had been prevalent in the black community throughout the 1960s, the gradual erosion of police - community relations in Portland's predominantly black Albina neighborhood posed the greatest threat to racial harmony within the city. ${ }^{5}$ Many of these concerns undoubtedly were part of the larger social and cultural context of the 1960s. Yet incidents such as those experienced by younger, militant, and more vocal members of Portland's black community like Hampton reflected components and aspects that seemed uniquely related to the Rose City's own experience with race relations.

By the late 1960s, the geographical boundaries of Albina had become relatively static. Covering an area of just over four square miles, the area's boundaries reached as far north as N.E. Columbia Boulevard and as far south as Interstate 84, even though most of the Black Community lived between Fremont Avenue on the south and Killingsworth Avenue on the north. Additionally, while the heart of Albina was centered between Mississippi Avenue on the west and N.E. $15^{\text {th }}$ Avenue on the east, the boundaries of the neighborhood extended further in each direction to cover families and communities unable to find housing in the more settled neighborhoods. Union Avenue, running north 
and south, ran straight through the King neighborhood, which, along with the Boise and Humboldt neighborhoods, had become the heart of the area. ${ }^{6}$

Portland was the second most segregated city of the six major urban areas located along the West Coast. ${ }^{7}$ While African-Americans totaled only 2 percent of the city's population in 1960, 80 percent lived in the Albina neighborhood. ${ }^{8}$ As a result of this racial disparity, black representation in city government and civic institutions was nearly non-existent. ${ }^{9}$ Racial strife also strained the delicate accommodation built up throughout the 1950s between Portland's "Old Guard" African-Americans and their white counterparts. Because the number of Portland's black citizens was so small, most white politicians had little incentive to acknowledge that problems of race and inequality existed in the Albina district, and seemed only capable of working to find tangible solutions to the area's problems when activists propelled them and in rare cases when election politics necessitated it. In fact, a 1957 City Club of Portland report on race suggested that city politicians and prominent business owners continued to deny that racism existed in the city.

The reluctance to advocate for racial progress and acknowledge the demands of local civil rights organizations also found repeated support in the local press. In cases like the argument between Percy Hampton and the police, the journalistic line of responsibility was often muddied in a narrative reporting of events that relied exclusively on local police reports. While not overtly discriminatory, journalism of this kind continued to perpetuate already existing fallacies concerning Portland's black population and more specifically, the Albina area's more radical and militant members. In 
particular, such reporting continually and often purposefully distorted the nature of altercations between the police and the African-American community.

Racism had a long history in Oregon. The state's first constitution, written in 1859 , enacted exclusion laws that prohibited blacks from living or owning property within its borders and perpetuated the mentality that Oregon would be explicitly inhabited and governed by whites. While free blacks challenged such laws, such as the seventy-five men who came to Portland by rail in 1883 to work at the Portland Hotel, it was not until 1926 that the most prejudiced and anti-black portions of the constitution were officially repealed. ${ }^{10}$ In the years prior to World War I, the vast majority of Portland's small African-American community lived near Union Station, with many exclusively black-owned businesses thriving along the northwest stretch of Broadway Avenue. With the construction of the Broadway Bridge in the early twentieth century, however, some African-Americans moved across the river to northeast Portland, bringing their businesses with them. Despite relative economic success for many blacks, racial discrimination still thrived throughout much of the city. While there were no segregated buses, restrooms, or drinking fountains, nearly all of Portland's schools, hospitals, and restaurants refused to cater to black patrons. The African-American right to vote, a sign of freedom that would not reach most blacks in the South until 1965, did little for civic progress in an overwhelmingly white city and state. Such a numerical disparity in the race of voters, as well as the polarized ethnic, religious, and racial ideology of the time, contributed to the 1922 election of Ku Klux Klan backed candidates for the offices of Portland Mayor, Chief of Police, County Sheriff, and Governor. 
During the Great Depression of the 1930s, African-American waiters, elevator operators, and busboys found themselves squeezed out of jobs to make room for white employees who had refused such positions only years earlier. As a result, most black men were forced into positions as Pullman porters or janitors, while most black women took posts in domestic housework. Meanwhile, Portland's exclusively white Realty Board and local politicians began moving blacks away from the downtown area into the Albina district across the river.

Written into the Code of Ethics of Portland Realtors, Article 34 stated that Portland realtors would never sell property within the city to members of any race or nationality whose presence would hurt property values. Encompassing groups such as African-Americans, Asian-Americans, and Jews, Article 34 allowed white realtors to funnel minority populations into the area between "Oregon Street and Russell, and between Union and the River." The code separated the cheap real estate and run-down housing of the Albina District from neighborhoods with higher property values reserved for future white buyers. ${ }^{11}$ Openly perpetuated by Portland's real estate agents, banks, and city authorities, "redlining" played a devastating role in creating not only the demographics of what came to be referred to as Albina, but contributed to many of the problems that continued to plague the District through the 1960s.

The growth in Portland's African-American population can be linked to America's entry into World War II. As a major port with easy Columbia River access to the Pacific Ocean, the Portland-Vancouver area hosted three Kaiser shipyards to outfit the Pacific theatre. Responding to the demand for workers, nearly twenty-five thousand 
African-Americans from all over the country, as well as nearly one hundred thousand whites, hopped on railroad trains and made their way to the Pacific Northwest. Assigned to the federally constructed public housing of Vanport City, so named because of its geographical location mid-way between Vancouver, Washington, and Portland, nearly forty thousand residents, forty percent of them African-American, joined the the second largest wartime city in Oregon.

As shipyard production drastically reduced at war's end, unemployment spiked among the city's former war workers. African-Americans were particularly hard hit. Finding employment in a place listed in 1945 as the "most discriminatory city north of the Mason-Dixon Line" by The Social Worker's Journal, was nearly impossible. ${ }^{12}$ Fifteen thousand African-Americans returned home to the southern and eastern states. Many of those who remained lost their places of residence in the Vanport Flood of 1948. Restricted from buying homes in most areas of the city, a perceived threat, as Mayor Earl Riley described it to Portland's "regular way of life," nearly all the blacks forced out of Vanport found themselves concentrated in the overcrowded Albina District. As more African-Americans moved into the area from temporary housing in Vanport, large numbers of whites left for the suburbs. ${ }^{13}$ Throughout the 1950 s, Albina lost one third of its total population; and by the end of the decade, had 23,00 fewer whites and 7,300 more blacks. ${ }^{14}$ With the passing of Oregon's Fair Housing Law in 1957, moreover, many affluent African-Americans fled to the suburbs or other residential areas, leaving less fortunate neighbors behind. 
By the mid-1950s, Portland city officials had targeted the area for urban renewal designed to meet the problems of encroaching blight. During the war, Williams Avenue, which ran through the heart of the black community, had served as the hub of AfricanAmerican nightlife with jazz clubs and bars that attracted music luminaries such as Duke Ellington and Ella Fitzgerald. ${ }^{15}$ Albina businesses as diverse as clothing shops, nurseries, and restaurants continued to flourish through much of the 1950s. Yet construction efforts on Interstate-5, which would run primarily through the Eliot neighborhood in lower Albina, diverted traffic away from many of these businesses, causing many to close down. Other urban renewal projects such as the construction of Memorial Coliseum and the subsequent erection of Emanuel Hospital had a profound impact on the area. Between the two projects alone, roughly four hundred homes and businesses were displaced, leading to an exodus of businesses east to Union Avenue.

Urban renewal ultimately led to the loss of nearly 1,100 housing units and over three hundred businesses. The result, one scholar has suggested, "brutally disrupted various aspects of residents' lives: economic, social, psychological, and spiritual." ${ }^{\text {16 }}$ "The emergence of the black ghetto did not happen as a chance by-product of other socioeconomic processes," wrote Douglas Massey and Nancy J. Denton in American Apartheid: Segregation and the Making of the Underclass (1993). "Rather, white Americans made a series of deliberate decisions to deny blacks access to urban housing markets and to reinforce spatial segregation." In short, concluded Massey and Denton, the structure of the black ghetto did not lend itself to permanence, but rather to the actions and inactions of the white political establishment. ${ }^{17}$ 
Because bankers and speculators often discouraged investment in Albina-area residences, housing stock had seriously deteriorated by the 1960s. Although many residents found employment as either clerical or service workers in the public sector, moreover, unemployment remained much higher among blacks than their white counterparts, while salaries for African-Americans were often lower than those for white employees. Albina public schooling also suffered. Because of the massive concentration of African-Americans living in the area, public education experienced a severe case of de facto segregation. A mere nine of Portland's ninety-four public schools, consequently, were tasked with the education of most of the city's black students. Citing poor graduation rates among the city's black public school students in comparison to white counterparts, the National Association for the Advancement of Colored People (NAACP) accused Portland Public Schools in 1962 of passively allowing segregated schooling. Follow-up reports by PPS tasked with investigating such accusations found that racial disparities did, in fact, prevail in city schools. Yet while the Portland School Board acknowledged that segregation existed, it refused to admit any inequality in the standard of education, choosing instead to blame poor black student scores and performances on cultural deficiencies.

By the mid-1960s, increasing numbers of Albina residents had become impatient with establishment temporizing in matters of racial justice and became more aggressive in demanding social equality. While the non-violent and integrationist civil rights movement in the South, led by leaders such as Martin Luther King, Jr., Bob Moses, and John Lewis, and organizations such as the Southern Christian Leadership Coalition 
(SCLC), Congress of Racial Equality (CORE), and the Student Non-Violent Coordinating Committee (SNCC), had yielded significant gains such as the federal Civil Rights Act of 1964 and the Voting Rights Act of 1965, the lingering presence of more subtle and covert forms of racism and inequality in the North had become a major issue of contention. Advocates for a more militant form of black activism such as Malcolm X saw folly in the strategy of the moderate and non-violent rights organizations. Arguing that civil and human rights were bestowed upon men by God at birth, rather than by the white politicians composing the statehouses and the halls of Congress, Malcolm X urged African-Americans to abandon the passivity of the non-violent movement in favor of a more assertive approach. This strategy, soon adapted by activists such as Stokely Carmichael, created a schism in the movement. A former follower of King, Carmichael referred to racial integration as "an insidious subterfuge for white supremacy" and rejected non-violence as a mere accommodation. Sensing the changing political landscape brought about by the emergence of a black populace displeased with the stagnation of the movement, leaders such as Carmichael sought to eradicate the passivity of previous generations by coining the phrase "Black Power."18

The formation of the Black Panther Party for Self Defense (BPP), founded in 1966 by Huey P. Newton and Bobby Seale, two community college students from Oakland, California, officially brought the concept of Black Power to a national audience. Envisioning the organization as a way for the black community to defend itself against an Oakland Police Department that was seen as racist and physically threatening, Newton and Seale depicted the BPP as a mechanism to provide the poor and 
underprivileged in their community with access to basic social services that local government failed to provide. This particular aspect of the organization, while a driving principle in its founding, tended to be overshadowed by the more radical demands of the group's Ten Point Plan, as well as its militant and imposing persona. ${ }^{19}$

In Portland, exposure to groups advocating Black Power was limited. Prior to the 1960s, the only black advocacy organizations in the city had been the NAACP and the Urban League, both nonviolent and reformist in philosophy. In 1961, however, a Black Muslim named Clarence Debiew, otherwise known as "Charles CX", opened a mosque on Williams Avenue, with the interest of introducing the Portland area to the black nationalist ideology of the Nation of Islam, founded by Elijah Muhammad. After persistent harassment by numerous residents, as well as a lack of support from much of the city, Debiew and his wife eventually left town, leaving behind their mosque and a small group of adherents. Yet by the late 1960s, many African-Americans in Portland had become much more accepting of a more militant approach including racial change through "any means necessary." By this time, local historian Darrell Millner has suggested, young African-American children of the shipyard workers had endured enough "and came of age as the Civil Rights Movement grew more confrontational.,"20

While there has been an extensive amount written on the African-American experience in Portland's Albina District, until Leanne Serbulo and Karen J. Gibson's 2013 Oregon Historical Quarterly article, "Black and Blue: Police-Community Relations in Portland's Albina District, 1964-1985," very little scholarship on the topic had focused on the antagonistic relationship between the police and community in the late-1960s and 
the subsequent troubles that arose as a result of it. While only briefly mentioning the disturbances of 1967, Serbulo and Gibson meticulously detail both the ineffectual behavior of city politicians to create greater racial equality and overt efforts by many in city law enforcement to harass and alienate black residents while prohibiting civil rights gains. Providing unambiguous accounts of police surveillance efforts, institutionalized racial discrimination, and a lack of leadership from the city's elected representatives, the article was invaluable for providing the context for the fear and paranoia that permeated Albina during the late-1960s. Jules Boykoff and Martha Gies's article in the Oregon Historical Quarterly, "We're Going to Defend Ourselves: The Portland Chapter of the Black Panther Party and the Local Media Response," while chronicling the genesis of the activism of Percy Hampton and Kent Ford, mainly examined the work of the Black Panthers in the 1970s and treatment of the Party in Portland's two largest newspapers. “Bleeding Albina: A History of Community Disinvestment, 1940 - 2000,” a journal article by Karen J. Gibson, provided extensive research on segregated housing in the city and the role of economic disinvestment. Yet Gibson merely mentioned the disturbances of 1967 and 1969 in passing. ${ }^{21}$ Another work, Ethan Johnson and Felicia Williams’s "Desegregation and Multiculturalism in the Portland Public Schools" explored the role of de facto segregation in precipitating the "large riot on Union Avenue" but left it at that. ${ }^{22}$

Two books, The History of Albina by Roy E. Roos and History of Portland's African-American Community (1805 to the Present), the latter commissioned by Portland's Bureau of Planning, both contributed necessarily small write-ups on latesixties unrest. Steven Reed Johnson's article "The Evolution of Civic Activism in the 
Albina Neighborhood," included a brief reference to the minor role that the turmoil of 1967 played in undermining traditional civil rights organizations of the area. ${ }^{23}$

This thesis will examine the manner in which Portland's black and white communities, law enforcement officials, city politicians, and local media responded to the changing racial dynamics within the civil rights movement of the late 1960s. Specifically, it will explore the root causes and motivations behind two separate racial disturbances in the Albina neighborhood in the summers of 1967 and 1969, as well as the effect these events had on the Albina neighborhood and its residents over subsequent years. The behavior of Portland's militant blacks, city government officials, and law enforcement officers will be scrutinized with the aim of determining to what extent each group contributed to the racial turmoil and how truthfully each publicly characterized their own role as well as that of their adversaries in these matters. The thesis also seeks to place the Albina disturbances in the context of national race relations in the late 1960s, as well as within the context of Oregon's own long and complicated racial history.

The primary sources utilized in this work fall into two categories. First, newspaper accounts of the incidents detailed in this study were invaluable for the day-today reporting of events, as well as for the editorials and op-eds that provided a glimpse into the mood and psyche of Portland's citizens and press. During the period of time that is the focus of this thesis, Portland produced two daily newspapers: the Oregonian, printed each morning, and the Oregon Journal, printed each afternoon. Additionally, the Willamette Bridge, an underground radical newspaper that began weekly circulation in 1968, served as an avowedly liberal voice on issues of local and national politics, and 
gave voice to Portland's small but burgeoning black militants. Lastly, the Oregon Advance-Times and Clarion Defender, both black-owned and operated newspapers focused much of their attention on the impact of local issues on African-Americans. Advocating for more moderate positions than Willamette Bridge, the Times and the Defender served as crucial resources to understanding the cultural attitudes and sentiments of Portland's moderate black citizens. Collectively, these newspapers provided a comprehensive look at the events as they unfolded, and spoke to the various groups in Portland who were invested on the account. In addition, the newspapers offered an abundance of key quotes and statements from the principal actors involved in many of the incidents, providing a historical record of many events that might otherwise have been left undocumented by history.

The second category of primary sources utilized in this thesis came from the Stanley Parr Archives and Records Center (SPARC) and the Oregon Historical Society (OHS). Included in these documents were a loose collection of internal memorandums, city police reports, and correspondence between city politicians and their constituents concerning issues of race, city governance, and the conduct of the Police Bureau. These records were invaluable to understanding how the city's politicians and community members viewed and spoke about the racial difficulties the city faced when they felt they could speak freely without judgment or public condemnation. Additionally, the letters and sentiments revealed that, contrary to narratives often pushed by local and national media outlets, there was not a singular or monolithic way of thinking about the issue of race in Portland. Advocacy or opposition for certain ideas and policies cut across not 
only the spectrum of age and class, but also race. Additional primary source material for the thesis came in the form of already existing oral interviews that were drawn on primarily for background information.

The time frame for this study is 1967 - 1969, with particular emphasis on two separate disturbances that occurred in late July/early August of 1967 and June of 1969. The text is divided up into four substantive chapters. Chapter One examines the roots and motivations behind the initial Albina disturbance in the summer of 1967, while the following chapter examines the reactions of Portland's community to that incident of violence and disorder. Chapter Three focuses on the efforts of both the AfricanAmerican community and the city's government to improve race relations in the wake of the disorder, as well as their response to larger national efforts at addressing the problems plaguing America's urban cities. Chapter Four centers on Albina's second major disturbance, lasting nearly a week in June of 1969, further exacerbating tense race relations in the community. Lastly, a Conclusion will examine the short-and-long term effects of the two Albina disturbances on area residents, businesses, schools, and community-police relations.

\footnotetext{
1 "Youth Charged with Offenses," Oregonian, May 25, 1969, 14.

2 "Victims Side of Club ... In a Planned Police Riot," Willamette Bridge, June 27 - July 3, 1969, 8.

3 "Youth Charged With Offenses," 14.

4 "Victims Side of Club ... In a Planned Police Riot," 9.

${ }^{5}$ Karen Gibson, "Bleeding Albina: A History of Community Disinvestment, 1940-2000," Transforming Anthropology 15 (2007), 4-22. Gibson's journal article asserts that Albina had, between 1940 and the early 1990s, been the target of redlining, predatory lending practices, and housing speculation that threatened the long-term viability of the community. By the middle of the 90s, Gibson argues, Portland's "low property values, renewed access to capital, and neighborhood reinvestment resulted in gentrifcation, displacement, and racial transition."

${ }^{6}$ Ibid., 7.
} 
${ }^{7}$ Annemette Sorenson and Karl Taeuber, "Indexes of Racial Residential Segregation for 109 Cities in the United States, 1940 - 1970,” Sociological Focus 8 (1970): 125 - 142.

${ }^{8}$ U.S. Census of Population and Housing, 1960: Summary Population and Housing Characteristics: Oregon. Washington: Government Printing Office, 1960.

${ }^{9}$ Sorenson and Taeuber, "Indexes of Racial Residential Segregation for 109 Cities in the United States, 1940 - 1970," 125 - 142.

10 "Local Color," May 1, 1999 (Oregon Public Broadcasting, DVD).

${ }^{11}$ E. Shelton Hill, interviewed by Elizabeth McLagan, 1976, Oregon Historical Society, SR 0267, 18-0312.

12 "Local Color," (OPB, 1999).

${ }^{13}$ Elizabeth McLagan, A Peculiar Paradise: A History of Blacks in Oregon, 1788-1940 (Georgian Press: Portland, 1980), 172.

${ }^{14}$ Ibid., 10.

${ }^{15}$ Robert Dietsche, Jumptown: the Golden Years of Portland Jazz, 1942-1957 (Corvallis: Oregon State University Press, 2005).

${ }^{16}$ Gibson, "Bleeding Albina," 14.

${ }^{17}$ Nancy J. Denton and Douglas Massey, American Apartheid: Segregation and the Making of the Underclass (Harvard University Press: Cambridge, 1993).

${ }^{18}$ Peniel Joseph, Waiting 'Tii the Midnight Hour: A Narrative History of Black Power in America (Owl Books: New York, 2006), 103.

${ }^{19}$ Huey Newton. War Against the Panthers: A Study of Repression in America (Writers and Readers Books, 2000), 11. The Ten-Point Program was initially conceived on October 15, 1966 in Oakland, CA.

${ }^{20}$ Darrell Millner, interviewed in "Local Color," (OPB, 1999).

${ }^{21}$ Gibson, "Bleeding Albina," 16.

${ }^{22}$ Ethan Johnson and Felicia Williams, "Desegregation and Multiculturalism in the Portland Public Schools," Oregon Historical Quarterly 111 (Spring 2010), 13.

${ }^{23}$ Roos, Roy E., The History of Albina: Including Eliot, Boise, King, Humboldt, and Piedmont Neighborhoods (Portland, 2008); Portland Bureau of Planning, History of Portland's African-American Community (1805-to the Present) (Portland, 1993); Steven Reed Johnson, "The Evolution of Civic Activism in the Albina Neighborhood," $\mathrm{http} / /$ www.google.com/url?sa=t\&rct=j\&q=\&esrc=s\&source=web\&cd=2\&ved=0CDQQFjAB \&url=http\%3 A\%2F\%2Fstevenreedjohnson.com\%2Fstevenreedjohnson\%2FCivicPdxAlbina_files\%2FAlbina\%2520Neig hborhood.pdf\&ei=pdEzUaizFIOgiALKtoHYCw\&usg=AFQjCNFMsKH7WW51IMgi5jzwRrfQE65wYw\& bvm=bv.43148975,d.cGE (accessed February 21, 2012.) 


\section{Chapter 1: The Disturbances at Irving Park (1967)}

As tensions escalated in the Portland Albina community during the summer of 1967, Mayor Terry Schrunk received an ominous warning from a self-described resident of the district. News of continued racial disturbances across the country coupled with conversations overheard on the bus, wrote Dd Loretta Wooster, had "many people, both

Negro and White, very much concerned and 'scared' that this will happen here."1 Urging the mayor to utilize his position by appearing on television, where he could remind the city of the inter-racial progress Portland had made as a community, Wooster pleaded that an intimate talk "could very well throw a tremendous amount of weight in the right scale in quelling the fear culminating in a lot of people before it can gain possible riotous momentum." Although the letter dismissed rioting in other cities as the work of dubious agitators, Wooster felt sure that Portland possessed only a few such individuals. Nevertheless, she insisted that people needed reassurance until "the wind dies down."3

Only a day before Wooster's letter arrived at City Hall, a sudden outburst of vandalism, initiated predominantly by African-American youths in the Albina district, sparked two nights of civil unrest, small scale rioting, and direct, and at times violent, confrontations between members of Portland's African-American community and the Portland Police Department. Dd Loretta Wooster's concerns, while accurate in their assessment of the resentment felt by many African-Americans in the district, had underestimated the speed with which the neighborhood's patience with city officials and police officials had disintegrated. 
In the two months prior to Wooster's letter, large-scale race riots had occurred in major American cities such as Tampa, Buffalo, Minneapolis, and Newark. Five days of rioting in Detroit, moreover, had left 43 people dead and more than 450 injured, with over 7,000 arrests, and more than 2,000 buildings destroyed. The scale and damage of the 1967 Detroit riots, coupled with an overall increase in the levels of racial unrest and disorder between blacks and whites in American cities since the Watts Riots in Los Angeles two years earlier, prompted President Lyndon B. Johnson to act. A day after the conclusion of rioting in Detroit, and on the same day Dd Loretta Wooster sounded her own alarm, Johnson appointed a National Advisory Commission on Civil Disorders, also known as the Kerner Commission, to investigate the causes of recent rioting throughout the country, and to offer recommendations regarding how to properly address them in the future.

While many urban areas of the country found difficulty achieving racial harmony in the summer of 1967, Portland was no different. Focusing on the contentious relationship between a predominantly white Portland Police Department and a predominantly black population within the Albina district, the Urban League of Portland undertook an Education and Youth Incentives program that year. The League aimed to build on earlier meetings with police to garner improved communications in Albina by "formulating a program that will establish positive police-community relations in the core area." " Limited recreational activities for black youth in the area, combined with perceived inequalities in treatment by police, had led to growing discontentment with their quality of life, and a more fertile atmosphere for a riot, suggested Frank Fair, a local 
black youth who worked for C-CAP (Church-Community Action Program), the social action arm of Portland's interracial and predominantly black community. "When you get to feeling locked in - that's when frustrations start," Fair explained to the Oregonian newspaper. ${ }^{5}$ Robert Nelson, an African-American businessman from Albina, added that Portland had all the reasons for a riot, arguing that most local black youths had "a ghetto complex."6 An Oregon Journal editorial in July titled, "Newark’s Message to Portland," drew a comparison between the New Jersey city's issues of urban decay, failing city schools, and white migration to the suburbs with those in Portland. The commentary pointed to the "weed seeds" of poverty and inequality in the city and stressed that "the public authorities who warn that it is far better to act before the city slides downhill, than to try to pull it back once it has slipped, are not crying wolf."7 Other citizens, unaffiliated with civic groups working at improving race relations but equally concerned about rising tensions within the community, also began speaking up. Writing directly to the mayor in late July, a "Portland resident and taxpayer" with the initials "E.H.B." attached a newspaper clipping from an Omaha, Nebraska newspaper describing the positive effect of hiring two Negro police officers. "It might help your already very fine police force if there were a few more Negro police here," the author advised. ${ }^{8}$

The battle over the necessity and frequency of police presence within Albina parks and neighborhoods was at the center of the antagonism between black youth and Portland police. By 1967, local police were consistently surveilling the neighborhood, a by-product of the establishment of the Portland Police Intelligence Division. Devised in the mid-1960s to closely monitor neighborhood civil rights activists and agitators, the 
Intelligence Division was tasked with the collection and dissemination of information on civil rights groups they targeted. Given such oversight, the police monitored those Albina residents who were actively involved in the area's civil rights movement.

Such supervision, however, did not go unnoticed by Albina's African-American residents. "Where else but in Albina do cops hang around the streets and parks all day like plantation overseers?" observed a local resident. "Just their presence antagonizes us. We feel like we're being watched all the time." 9 Additionally, the Intelligence Division was given orders to intervene at any gathering, rally, or event, and to make arrests if such situations necessitated it. ${ }^{10}$ While Albina residents charged the police with unwarranted surveillance of their neighborhoods solely on the basis of race, police officials responded that, in a show of good faith, they had specifically refused to "set up a special force for dealing with these areas" in an effort not to alienate the local population. ${ }^{11}$ Reverend Paul Schulze, a local pastor, addressed C-CAP on the concerns of local Albina youth regarding the role of the police in the area. Youth in the Fremont and Union area, noted Schulze, often congregated under the surveillance of police who continued to pursue a policy of containment rather than actual intervention. ${ }^{12}$ A participant in Operation Contact, a program aimed at delinquent youth on the streets of Northeast Portland, the minister recounted the tenuous dynamics at play between black youths, local police, and the news media. On one occasion, Schulze referred to the indifference of a police officer unwilling to get out of his car to break up a violent parking lot fight between two blacks. On a separate occasion, the pastor spoke to disappointment about a newspaper article about a small conflict that occurred at the conclusion of a youth dance at Irving Park: "A 
potential riot was there, but most youngsters maintained their cool and did not get involved in rampaging property," he noted. Yet Schulze complained that the following day's newspapers treated the event "as a 'riotous rumble' and consciously or unconsciously featured the story in conjunction with riot situations in Cleveland and Chicago." 13

Despite mounting signs of resentment between police and much of Portland's black community, several politicians disputed any possibility of racial violence. Speaking to a group of reporters at a late-July news conference, Governor Tom McCall claimed he possessed no information that would lead him to believe racial violence similar to that occurring throughout the Midwest and East would occur in Oregon. Citing poor job opportunities, troubled schooling, and the presence of an urban ghetto, McCall acknowledged that race relations in Oregon were not "perfect." Yet he contended that the relationship between the state's whites and blacks was much better than those in many other states. Nevertheless, the governor explained that a dialogue with the black community was necessary. "We must try to just as hard as Newark and Detroit to right these tremendous wrongs," he concluded. ${ }^{14}$

Four days later, McCall again spoke to the topic of racial rioting throughout the country, stating that he was concerned regarding "the breakdown in orderly democratic process." Arguing that rioting would not solve problems and was "alien to America's institutions," the governor again cited unemployment, inadequate education, and substandard housing as issues that cities and governments must address to nullify the increasing levels of discontent and anger in impoverished communities. McCall said his 
staff was making every effort "to meet the responsibilities of the state toward correcting imbalances. We are keeping avenues of conversation open. We are in contact with the people and their organizations in the affected groups." ${ }^{\prime 15}$

Following the palpable increase in tension in the Albina area in the days leading up to the disturbance, many community leaders made efforts to defuse the situation. Rumors had circulated that a demonstration might occur over the last weekend of July in connection with a rally featuring militant Black Panther Eldridge Cleaver at a "Sunday at the Park" program. ${ }^{16}$ Promoted by the "Ad Hoc Committee for Black Culture," the program was to feature not only the well-known Ramparts writer and activist, but a Black Arts Theatre from San Francisco, a Student Nonviolent Coordinating Committee (SNCC) photo exhibit, and live music. In the week leading up to the scheduled rally at Albina's Irving Park, two black ministers, Reverend John H. Jackson, a well-known area pastor from Mt. Olivet Baptist Church, and Bishop William McKinney, visited local bars, barber shops, and pool halls in an effort to learn as much as possible about the event. Working to convince as many of the young male patrons as they could not to participate, the two were met with "a cool reception" and were told that they "did not know what kids would do today." 17 On the Friday of that weekend, when many of the teenagers who spoke to the ministers had predicted there might be a riot, a youth dance proceeded in the neighborhood without any altercations, leaving many locals to breathe a sigh of relief.

On July $29^{\text {th }}$, the day before the scheduled rally, the Albina Ministerial Association presided over an urgent gathering of local pastors, priests, and ministers. The meeting produced an announcement to be read at church services the next morning, 
urging parents to keep their children off the streets, out of the parks, and away from the rally. Indeed, many of the community's pastors used their Sunday pulpits to advise youth in attendance to abstain from visiting Irving Park because the likely sponsors of the rally were criminals, intent on starting a riot. Colden Brown, Jr., a young African-American from Berkeley, California, who spent the summer of 1967 in Portland teaching Black History and Jazz for Reed University's Upward Bound program, remembered going to church where we heard a letter read to the 'flock,' telling us to stay away from Irving Park," because a riot would "get a lot of Black people killed and maimed.",18

Despite the efforts of local elders, Irving Park had clearly become a focal point for area residents, as well as police, on the morning of July 30th. Colden Brown, one of many Black Power advocates intent on speaking during the "Sunday in the Park" rally, saw a potential conflict looming when he emerged from his home that day: "On the way to church, we saw the National Guard, in a big show of force." ${ }^{\prime 19}$ Furthermore, Brown's group of black activists, who intended to use the park in the afternoon for the gathering, had not applied for a park permit, and would be in violation of the city ordinance requiring one. Citing the city's lack of permit enforcement for parks predominantly patronized by whites such as Lair Hill, Brown saw a pattern of racism in such discrepancies. "Irving Park is the Black peoples' park, just like Lair Hill is for the hippies," he later noted in an opinion piece in Portland State College's Vanguard newspaper. "The FBI, police, and National Guard never show up [there]. Because our activity was sponsored by blacks for blacks, the city fathers decided that it would need 
policing. After all, they seemed to be implying that Black people cannot police themselves.",20

By early Sunday afternoon, the day's bright and sunny weather had attracted nearly one hundred patrons to Irving Park. ${ }^{21}$ In one area of the park baseball games were being played, in others, the tennis courts were occupied, and in yet another, children were sliding down slides and playing on the equipment. Other individuals, many of them teenagers and young adults, were merely milling around the area in anticipation of the afternoon rally and speeches. Many of the latter, including young black activists such as Brown who were frustrated and unhappy with local government and community leadership, saw their meeting as an opportunity for local blacks to take matters into their own hands, and to protest worsening conditions in their neighborhoods. Others, knowing only of the scheduled appearance of Eldridge Cleaver, were likely composed of both Portland residents as well as outsiders who had made the trek exclusively for the rally. The rest of the crowd included people likely anxious for potential conflict, others interested in preventing it, and some merely curious about what was to commence.

As the local black speakers arrived at the park by afternoon to begin their portion of the event, it became apparent that the rally would not proceed as planned. Keynote speaker Cleaver had not yet shown up, and rumors circulated that he had been detained at some point on his trip with the Black Arts Theater. The presence of additional law enforcement officers, in the form of seven cars of plain-clothes detectives, the continual circling of local police cars, and two law enforcement officers on a hill with binoculars, further exacerbated the situation. ${ }^{22}$ Despite the rally's seeming lack of organization, 
Colden Browne and several black speakers used their own P.A. system and microphone to begin speaking to the assembled crowd about the necessity of revolution in the black community to combat police harassment and brutality. Erma Hepburn, a Neighborhood Service Center worker, did not recognize the majority of the men who made up the group of black activists. "There was no rally as such," she told the Oregonian. "There was very little organization of any kind. The speakers - I'd say there were between 8 and 12 - tried to get things going ... but young people in the park kept jeering them." 23

According to an Oregonian report, individuals in the crowd who had been drinking cough syrup and wine and playing dice, began to harass the speakers by interrupting their messages with hooting and cat calls. More militant elements at the park, however, eventually succeeded in grabbing the microphone and began chanting "kill the honkies" and "burn the town down," before beginning their efforts to recruit a mob of bystanders to break into a local store to grab guns. Upon hearing such conspiring, the rally's speakers responded that while they were not there to start a riot, "if you're here to talk about a revolution, then that's something else." ${ }^{24}$

As tensions built, more of the crowd became increasingly agitated by the increasingly visible police presence in the park. Meanwhile, Reverend Jackson observed the situation from a car parked across the street: "I heard a lot of bad language and statements about' getting white people.' But not everybody at the rally was in agreement with the speakers," he told the Oregonian. "I heard several people in the audience say it [rioting] wouldn't work. The others kept saying it would."25 Frustrated by interruptions and the behavior of certain members of the crowd, the group of black speakers grabbed 
their sound equipment and left the speaking spot near the park's wading pool, reestablishing themselves at a hollow in the center of the park, where they again began to hold forth. ${ }^{26}$

While the majority of the people present at the park seemed opposed to the ideas of riot and revolution proposed by some of the speakers, a smaller minority of more militant youths had taken the message to heart, chanting "Whitey, Go Home!" at various white members of the crowd. Two white men present at the rally that day, Ira Williamson, a 51 year old employee of the Portland Parks Department, and Vernon Wolvert, an employee of the University of Oregon Medical School who lived across the street from the park, were the first casualties of the day's violence and unrest. At about 5:30 p.m., and with the relatively large crowds at the park beginning to disperse, the two men, who had previously been observing the rally with several other adults, mainly African-American, found themselves attacked by a group of young black men. Suffering five broken teeth, cuts to his mouth, multiple bruises to his ribs, and the theft of his wristwatch and wallet, Williamson had been surrounded by a group of black youths who began to push him around the circle, repeatedly punching him and prohibiting him from falling down to brace himself. ${ }^{27}$ Remaining conscious throughout the beating, Williamson had been kicked twelve times before Linzi Roy, a black school teacher working in the park bureau's summer program, intervened by dragging Williamson out of the park and into a nearby building, before having him taken to the hospital. Vernon Wolvert, while also physically attacked in the aftermath of the rally, had not been severely hurt. ${ }^{28}$ In recounting the experience days after the attack, Williamson indicated 
that his assailants were not individuals he recognized as frequent patrons of the park, citing that many of them were older than the people he worked with daily. ${ }^{29}$

As the nature of the events at Irving Park quickly shifted from a rally to a clash, the prospect of conflict with local police seemed inevitable. The day's first report of violence, listed at 5:18 p.m. by Portland Police Inspector Frank Springer, pertained to a group of black youths armed with clubs who threw bottles and rocks through the windows of the Lampus discount store. By 6:30 p.m., reports of extensive rock throwing directed towards passing motorists and police officers precipitated both the sealing off of a thirty block area of the neighborhood as well as the request of additional police officers to aid in the patrolling of the troubled area. ${ }^{30}$ Those loitering around Irving Park, where many of the problems had begun, and which served as the epicenter for much of the disturbances throughout the night, often found themselves the target of a police force attempting to clear the area to prohibit the further progression of vandalism and violence. In addition to the police, two local preachers, O.B. Williams and Reverend Wendall Wallace, part of the Albina civilian community's effort to quell the disturbances, were also asked to head to Irving Park to dissuade teenagers from rock and bottle throwing in the area. One youth, a local fourteen year old interviewed in the Oregonian the following day, was picked up and detained overnight for merely being present at the park, something he felt was not all that uncommon: "I wasn't rioting, just standing in the park. Those cops pulled up and began grabbing everybody. I was one of the ones they grabbed. I was just listening to a man talk."31 
Despite police efforts to crack down on potential problems around Irving Park, numerous other disorders occurred throughout the district that evening. A clothing store at the corner of NE Williams and Knott Street, while having been broken into and partially vandalized, was not robbed or looted. Along Union Avenue, between Fremont Street and Beach Street, many local businesses, such as Lincoln Park Grocery, Stereo Unlimited, and Paramount Linoleum, suffered broken windows from thrown bottles and rocks from passing cars. Stereo Unlimited, located along Union Avenue, was the lone store to have been looted Sunday night, although the damage was limited to a few stereo tapes. Of far greater significance were a series of fires that had broken out throughout Albina before being placed under control. The largest, taking place at a two story building on Union Avenue that housed both the Union Coin Operated Laundromat and American Auto Parts, Inc., broke out shortly after 10 p.m. as the likely result of a firebomb. ${ }^{32}$ Another fire, while not as large, erupted at the Sav-Mor Food Market on N. Mississippi Avenue, and constituted the most expensive conflagration of the evening, causing nearly $\$ 20,000$ worth of damages. ${ }^{33}$ A fire bomb tossed through the window of the Alberta Furniture Store led to the night's lone shooting, when police officers fired on Jesse Johnson, a black eighteen-year old, after they observed him hurling a Molotov cocktail through the store window. Taken to Multnomah County Hospital, where many victims of the riot were already being treated with cuts, scrapes and bruises, Johnson survived the buckshot injuries to his back, legs, and stomach, and was booked on arson charges with a $\$ 5,000$ bail. $^{34}$ 
Ten other smaller fires, also likely the result of fire bombs, had broken out as well before firefighters adequately extinguished them before midnight. Tom Potter, a beat officer in the Sellwood neighborhood at the time, and later both Chief of Police and Mayor of Portland, recounted the scene he faced at the outset of the racial demonstrations:

The police were not prepared for what was coming down the pike. We went out there with very little training, very little equipment and a huge gulf between us and the African-American community. On one occasion, I remember standing at what was then NE Union and Fremont. Every building within my line of sight was on fire. There were people in the streets. I heard occasional gunfire. ${ }^{35}$

Journalist Ralph Friedman, covering the event for the Oregon Journal, reported the response of a local black man to the rampant vandalism. "Tell them the white merchants on Union Avenue could have 10 Union Avenues for all the profit they've drained out of us," he stated. "Tell them Portland stinks behind its roses. Tell them we're not monkeys and this isn't a zoo."36

As Portland police authorities continued their efforts to successfully combat the civil unrest throughout Albina that evening, Mayor Terry Schrunk and Governor Tom McCall began to develop the political response to the situation. Having arrived in Portland around 9:00 p.m. that evening, McCall and Schrunk, along with the heads of the Oregon National Guard; Major General Donald Anderson, Oregon's adjutant general; Holly Holcomb, the head of the state police; and various other members of the governor's staff, met at the Hilton Hotel, where they began to monitor and discuss the disturbances. ${ }^{37}$ While McCall and Schrunk strategized, Police Inspector Frank Springer, speaking at a press conference arranged by Portland Chief of Police Donald I. MacNamara, gave the 
city's first statement on the situation. Recounting the events that began at Irving Park earlier in the day, as well as the events still unfolding around him at that moment, Springer was clear in making the point that circulating rumors of black violence throughout the city such as sniper firing and looting had been unconfirmed. Presented with the situation in its existing form, moreover, neither Springer nor any other representative of the Portland Police Department considered the disturbances to be a riot. ${ }^{38}$ While little else of Springer's remaining briefing was of note, he did address inquiries from local black residents in the area as to how they might contribute to helping stem the unrest. Springer responded that if they felt so moved, their assistance in diffusing tensions in the most fragile and tenuous areas of the district would be greatly welcomed. ${ }^{39}$

Following their meeting at the Hilton, both the mayor and governor reconvened at the mayor's office, where an informal command center was set up for the duration of the evening and morning. Asked of his initial impressions of the situation, McCall responded that every precaution was being taken by local police officials and city leaders, and despite the situation still being "in flux," he believed Portland to be in good shape and "coping." 40 Mayor Schrunk, unable to get a telegram off to the Oregon congressional delegation in Washington earlier in the day, sent a note between 11:30 p.m. and midnight providing details of the situation: "Portland disturbance is very minor and not a riot. Portland officials have situation well in hand. We have provided backup as an additional precaution. Will advise if this status changes. ${ }^{41}$ As McCall and Schrunk maintained their vigil at City Hall, the police continued attempts to keep congregating crowds of youth, 
nearly three hundred young men and women at the height of the disturbances, from moving.

Of the four hundred police officers present in Albina, only two hundred were immediately ordered into the area, where they were given the task of riding, four and five to a car, with orders to nullify and prevent disorder. Given orders to wear helmets at all times and to keep their rifles and shotguns in the cars and out of the public's view, the behavior of the police force was to be one of steady but subtle progress in clearing the area. Two hundred other officers were also on standby, having been called in from other parts of the city, as was the Oregon National Guard's $2^{\text {nd }}$ Battalion of the $218^{\text {th }}$ Field Artillery, consisting of five hundred men in reserve at the Portland Air Base, and another six thousand reservists at home. In addition, state police were on alert and in reserve south of Portland, in Milwaukie. Each of those reserve forces was ready to move within fifteen minutes of notification. ${ }^{42}$

By midnight of Sunday, nineteen individuals - thirteen adults, three of which were white, as well as six juveniles - had been arrested on a variety of charges. Shortly after midnight, and as a result of orders by the mayor to do so, police officers began to round up and arrest any individual - black or white - on violation of a city curfew ordinance implemented only hours earlier, further helping to clear the seventy square blocks of the problem area. By 12:30 a.m. Monday morning, despite Police Inspector Frank Springer's official declaration that the situation in Albina was clear and under control, circumstances proved otherwise. Between 12:30 a.m. and 3:30 a.m., the Portland Fire Department received fifteen more fire calls, bringing the number of fire calls since 
5:00 p.m. the previous day to a total of twenty-six; all of which were directly related to the disturbances in the area. Twenty-eight more individuals, seventeen of which were white and eighteen of which were juveniles, were arrested in the early morning hours, with many of the whites arrested on violations of carrying guns in their cars through the problem areas.

Newspaper responses to the Albina disturbances, with only a few exceptions, were overwhelmingly critical of youth charged with instigating the turmoil and praiseworthy of the police. The front page of the Oregonian, featuring a picture of six armed Portland police officers forming a human blockade on Union Street late Sunday night, set the tone for much of the day's discourse headline blaring, "Negroes Break Windows, Set Fires" and a sub-headline, "Police Move to Put Down Disturbances." In the Oregon Journal, the tepid lead headline, “Albina 'Quiet' After Racial Flareup,” was overshadowed by the hyperbolic lead article on the disturbances, "Gangs Burn Stores; Youth Shot; 6 Hurt,” which neglected to place context into which races were involved, and in what context such acts occurred.

In the seventeen stories written about the event that appeared in the two main Portland papers the following Monday, fifteen of them drew a clear antagonism between the black community and police force. Only two articles attempted to speak to the root causes of the disturbances or to try to place them within the context of the larger urban unrest and race riots taking place throughout the country that summer. Staff writer Stan Federman's front page story in the Oregonian described "roving bands of negroes" who "surged through the streets" carrying out "scattered acts of vandalism," whose delinquent 
behavior was only subdued when police moved "swiftly and calmly" to quell the trouble. ${ }^{43}$ Significantly, Federman's dispatch made no reference to the twenty white males who had also been arrested nor made any mention of the role of the Portland police force in the confrontation. Nor did either newspaper offer anything approaching nuanced coverage of the problems of racism and their role in precipitating much of what had occurred.

To nearly all of the adults and elderly living in Albina, regardless of race or gender, the outbreak of violence in the community was seen as saddening and deplorable. Many blacks, such as Bennie Carson, who lived in the area and saw his business set on fire, viewed the previous night's disturbance as a setback in race relations: "After all the progress," Carson lamented to the Oregon Journal, "it's just a damn shame. It was a bunch of young folks who hurt all of us."44 Many residents blamed the outbreak on 'outsiders' from other areas of the country, who had come to Portland to create unrest. Al Rivers, a local businessman, asserted that the tranquility of black life in Portland could have only been shattered by individuals from outside Oregon. "There's no trouble in Portland like they have out east," he told the Journal. "The police could stop this in a minute by simply driving the agitators outside of town. We don't want young punks who are simply following along, acting up for no reason at all. The cops ought to get real tough with them."45 Leroy Loos, also of the area, argued that the situation was inevitable. "Everybody knew it was coming," he observed. "And they'll probably be more tonight. All of us, colored and white neighbors alike, have been knowing this would happen and hoping it wouldn't. They had outsiders coming in to stir the young 
ones up. Nobody in Albina who has any sense was in on it." ${ }^{46}$ Otto Rutherford, a prominent member of the Portland civil rights movement, stated that it was obvious that the dissension occurred as a result of outsiders because "we don't have too many rabble rousers. Fundamentally, our kids are pretty decent kids. And we have no tenements in the truest sense." ${ }^{47}$ One of the community's black leaders, John H. Jackson, Mt. Olivet's Baptist Church pastor, stated that he was "positive" the disturbances were caused by outside agitators. Jackson claimed it was common knowledge, both throughout the Albina community and among city government officials, that a rally planning meeting had taken place among a number of individuals who had driven up to Portland from various parts of California. ${ }^{48}$

Others in the community saw the flare-up as the senseless result of restless teenagers, many of whom were already known to social welfare and church groups, and young adults, likely unemployed and already volatile, who made poor decisions and gave vent to their summer boredom. Mayfield Webb, a prominent member of the AfricanAmerican community, saw two main factors at work. "One was the rally in Irving Park, and the other was the group of youngsters that caused disturbances," he stated. "Whether the youngsters and the rally were directly connected, we can't say."49 A local white shop owner, despite having his store windows broken, spoke to his view of the mayhem: "People here are good people," he told the Oregonian. "We deal with them day in and day out and have never had any trouble before. It's the kids. We heard a lot of rumors about a possible outbreak this past week - but still, this is all pretty unexpected for us.",50 An Albina resident, Emma Hatten, also saw the behavior of the local youths as irrational, 
given her perception of the racial dynamics that existed in Portland at the time: "It's a bunch of young ones getting all excited. I don't know why," she declared. "The white people in Portland have been real good. We don't have any trouble at all. Now I think we'll move out of here." ${ }^{51}$ Others, such as Jerry Brown, a white Albina resident, saw the stereotypes such behavior created as unequal and misleading: "If white kids did something like this it wouldn't reflect on the rest of us, but this way it's not the same, and that's too bad," he stated. "I know a couple of carloads of white men were pulled in and they were carrying rifles. That's where the real trouble starts - with the looters who try to take advantage."

\footnotetext{
${ }^{1}$ Dd Loretta Wooster, letter to Terry Schrunk, July 28, 1967, City of Portland, Schrunk papers, Stanley Parr Archival and Record Center, Portland City Archives, AF/167044, A 2011-002.

${ }^{2}$ Ibid.

${ }^{3}$ Ibid.

${ }^{4}$ Urban League of Portland, "Education and Youth Incentives Projections for 1967," Urban League of Portland Annual Report (1966-1967), 1966.

${ }^{5}$ Gordan Macnab, "Portland's Teen-age Negroes Refuse to Bear Frustrations of Parents," Oregonian, June 1, 1967, 4M 15.

${ }^{6}$ Ibid.

${ }^{7}$ Editorial, Oregon Journal, July 21, 1967, 3M 14 J.

${ }^{8}$ E.H.B., letter to Terry Schrunk, July 27, 1967, City of Portland, Schrunk papers, Stanley Parr Archival and Record Center, Portland City Archives, AF/167044, A 2011-002.

${ }^{9}$ William Sanderson, "Bitter, Frank, Articulate Youth of Albina Speaks Up," Oregonian, August 6, 1968, $6 \mathrm{M} 4 \mathrm{~J}$.

${ }^{10}$ Karen J. Gibson and Leanne C. Serbulo, "Black and Blue: Police-Community Relations in Portland's Albina District, 1964-1985," Oregon Historical Quarterly 114:1 (Spring 2013): 12-13. Gibson and Serbulo's article is invaluable to contextualizing the antagonism and tension felt by many Albina blacks towards the law enforcement officers who served their community.

${ }^{11}$ Macnab, 4M $15 \mathrm{~J}$.

${ }^{12}$ C-CAP notes for discussion at general meeting, June 6 - June 24, 1966, Oregon Historical Society, Albina Vertical File 1 of 3 (Albina in the 60s).

13 Ibid.

14 “Race Riot Here Held Doubtful," Oregon Journal, July 25, 1967, 5M 12 J.

15 “McCall Concerned By Racial Rioting,” Oregon Journal, July 29, 1967, 5M 5J.

16 “Ramparts Editor Main Attraction," Oregon Journal, July 31, 1967, 5M 4J.

${ }^{17}$ Robert Olmos, "Negro Leaders Declare Albina Refuses to Accept Black Power Theory," Oregonian, August 1, 1967, 6M 16.

${ }^{18}$ Colden Brown, Jr., "Rapping About Albina," Vanguard, September 27, 1967, 10.

${ }^{19}$ Ibid.
} 
${ }^{20}$ Ibid. Despite Browne's claim, James Tucker has documented the manner in which patrons of Lair Hill Park clashed with Portland police and city officials over the use of park facilities. Tucker predominantly focuses on the manner in which city officials attempted to marginalize the presence of the counterculture in Portland, which had found the Lair Hill area receptive to their values. See "Culture War: the Battle for Portland's Lair Hill Neighborhood, 1968" (Portland State University M.A. thesis, 2007).

${ }^{21}$ Olmos, "Negro Leaders Declare Albina Refuses to Accept Black Power Theory."

${ }^{22}$ Brown, Jr., "Rapping About Albina."

${ }^{23}$ Olmos, "Negro Leaders Declare Albina Refuses Black Power Theory."

${ }^{24}$ Ibid.

${ }^{25}$ Robert Olmos, "Portland Negro Leader Claims 'Outsiders' Sparked Albina Youths' Disorder," Oregonian, July 31, 1967, 8M 17.

${ }^{26}$ Olmos, "Negro Leaders Declare Albina Refuses Black Power Theory."

27 "Negro Gang Assaults 15 Year Park Veteran," Oregonian, August 1, 1967, 6M 16.

${ }^{28}$ Ibid.

${ }^{29}$ Ibid.

30 "Gangs Burn Stores; Youth Shot; 6 Hurt," Oregon Journal, July 31, 1967, 1.

${ }^{31}$ Judd Smith, "Negro Youths Trace Albina Unrest to Racial Warfare in Other Cities," Oregonian, August 1, 1967, 6M 17.

${ }^{32}$ Stan Federman, "Police Move to Put Down Disturbances," Oregonian, July 31, 1967, 1.

33 "Gangs Burn Stores; Youth Shot; 6 Hurt," 1. The thirty block area was bounded by N. Vancouver Avenue, NE Weidler Street, NE Union Street, and NE Failing Street.

${ }^{34}$ Ibid.

${ }^{35}$ Ryan Frank, "Potter on Riots, Redevelopments," Oregonian, June 15, 2006, 13.

${ }^{36}$ Ralph Friedman, "Sudden Mood Change Frightening At Scene of Riot," Oregon Journal, July 31, 1967, J5.

${ }^{37}$ Harold Hughes, "McCall Eyes Strife Scene,” Oregonian, July 31, 1967, 1.

${ }^{38}$ James Hill, "Officers Seal Off District in Albina to Curb Disorders By Teen Gangs," Oregonian, July 31, 1967, 6M 14.

${ }^{39}$ Ibid.

${ }^{40}$ Hughes, "McCall Eyes Strife Scene."

${ }^{41}$ Terry Schrunk, telegram to Oregon Congressional District, July 30, 1967, City of Portland, Schrunk papers, Stanley Parr Archival and Record Center, Portland City Archives, AF/167044, A 2011-002.

${ }^{42}$ Hughes, "McCall Eyes Strife Scene."

${ }^{43}$ Federman, "Police Move to Put Down Disturbances."

${ }^{44}$ Bill Collins, "Saddened Albina Residents Angry at Rioters," Oregon Journal, July 31, 1967, 5 J5.

${ }^{45}$ Ibid.

${ }^{46}$ Ibid.

${ }^{47}$ Charlie Hanna, "Need For More Jobs For Negro Youths Cited By Officials Of Urban League," Oregonian, August 1, 1967, 6M 16.

${ }^{48}$ Olmos, "Negro Leaders Declare Albina Refuses to Accept Black Power Theory."

${ }^{49}$ Hanna, "Need For More Jobs For Negro Youths Cited By Officials Of Urban League."

${ }^{50}$ Stan Federman, "Albina Adults Deplore Strife, Help Police Rout Gangs," Oregonian, July 31, 1967, 6M 14.

${ }^{51}$ Collins, "Saddened Albina Residents Angry at Rioters."

${ }^{52}$ Ibid. 


\section{Chapter 2: Public Response to the Irving Park Disturbances (1967)}

While the initial aftermath of the Irving Park disturbances led to debate regarding who was responsible, there seemed to be, with few exceptions, commendation and esteem for the Portland police officers charged with quelling the commotion. Adult and elderly Albina residents, both black and white, were nearly unanimous in their applause of the police's conscientiousness and deftness in handling what could have been an explosive situation. A black Albina woman, speaking as a community member, stated that "the entire black community is as upset about this as the rest of the city is. It's a pretty tense situation for everyone and it takes a great deal of common sense by everyone to handle these kids."1 J.D. Millner, an African-American businessman, located within the Albina District, wrote to Mayor Schrunk that the police had been courteous and polite throughout the disturbances. Referring to the disorder as "minor troubles," Millner insisted that, as a black business owner in a predominantly black area, "I can't afford to see our property go up in smoke. My people are only hurting themselves." He closed by sounding a refrain heard among many black adults that the community could not gain "by rioting and breaking the law, and the guilty ones should be punished to the full extent

of the law." Katharine T. Noyes, a Portland resident of unknown racial background, praised the mayor's "great success" in handling the city's racial problem and suggested that he read a recent Parade magazine article titled "A New Way to Stop Race Riots."

An entirely different response emerged from several young members of the Albina community. To many black youths, the confrontations served as an attempt to 
redress injustices and inequalities that had pervaded police-community relations in the neighborhood for years. "There's a new awareness in these kids," stated Frank Fair, a member of C-CAP and Albina's Operation Contact. If Albina was going to be treated as a separate area by city officials, Fair argued, then "they'll have to deal with their problems in those terms.. ${ }^{4}$ The necessity of nearly four hundred armed police officers backed up both by National Guard and state police to subdue seventy five to eighty local teenagers and young adults served as a microcosm of the racism they believed the Portland police department customarily demonstrated towards Albina's blacks. Colden Browne, Jr., one of the speakers at Irving Park during Sunday's events, spoke to the atmosphere that existed in Albina. On Monday, he explained, "everyone for the first time in their Portland lives, got sober, looked out in the streets which were still occupied, and saw what THE BEAST really intended to do to them (a concentration camp can be made of Albina in 16 minutes).",5

Among activists such as Browne, the portrayal of the events as a calculated uprising by black radicals was not only dishonest but failed to account for the tensionraising pre-rally presence of the police at Irving Park. Brown saw the assertion by Ron Schmidt, Governor McCall's Press Secretary, that "Black Power Negroes have come into Portland" as an overreaction and as inherently misleading, since authorities at the time could not determine what the relationship was, if any, between the rally at Irving Park, and the violence that erupted throughout Portland that night. ${ }^{6}$ "These honkies in Portland would like to blame 'outside agitators,' communists, or men from Mars," asserted one 
Albina resident. "Anything to sweep it under the rug and forget about it.", For Browne, the press and police had worked in concert to portray the event as a riot, despite direct statements given by Springer, Schrunk, and McCall, that given their information on the situation, the disturbances could not be so classified. ${ }^{8}$

On the following morning after the disturbances, Portland city officials as well as Governor McCall were determined to downplay the events of the previous night. In a press conference that day, Police Inspector Frank K. Springer stated that nearly all of the incidents from the night before had dissipated between midnight and 2:30 a.m. and that while it was “a tense and difficult situation, it didn't really seem to have gotten out of control." Springer added that as of 7:03 a.m. that morning, the police had returned back to their normal routine. Police Chief Donald MacNamara stated that because there had not been a great deal of agitation or retaliation by whites, he did not expect the disturbance to flare up again. Yet MacNamara acknowledged that he had ordered “intensified patrol" by cops on the street. ${ }^{9}$ Speaking of a joint press conference, Mayor Schrunk and Governor McCall reiterated that neither man viewed the events of the previous day as part of a race riot; that while there was some evidence to conclude that outside agitators had played a role, a small minority of the troublemakers had been Albina residents; and that advance planning for such racial trouble, particularly in the form of riot training, played a crucial role in the success of de-escalating the situation. ${ }^{10}$

"The mood of Portland's non-whites is one of intolerance towards violence," declared McCall, adding "that the seeds of hatred find inhospitable roots in Portland." 
The governor also insisted that the black community should not be painted as a whole as a result of the behavior of a small group of individuals. The only controversial aspect of the McCall-Schrunk press-conference may have come when both men laid partial blame for the violence and vandalism on two Portland Public school levies that voters had failed to pass. In a joint statement, the two political leaders contended that "the inability or the disinclination of the citizenry to finance adequate education programs is a root cause of the major sociological dilemmas of the American metropolis." $" 11$

Beyond issues of school funding, several community leaders and social activists tied youth unrest to structural issues. To many critics, the biggest obstacle to a calm and tranquil Albina neighborhood was deep-seated unemployment and a lack of job training opportunities. An Oregonian feature two days after the incident pursued this theme by interviewing several labor and civil rights experts throughout Oregon. Mark Smith, director of the civil rights division of the Oregon Bureau of Labor, pointed to the fact that unemployment rates among Negroes were twice as high as among whites, a reality reflected in the schools, social services and community activities. ${ }^{12}$ Groups such as the Portland Urban League argued that prejudiced employers contributed to the disparity in unemployment rates, yet the Multnomah County Labor Council insisted there was “absolutely no discrimination" in organized labor's role in hiring or training. ${ }^{13}$

Seeking to move beyond the debate on unemployment and job training, a nineteen member meeting of city government liaisons, C-CAP members, and Albina Community Action Program Members, known as the Metro Steering Committee commenced the 
night after the disturbances. Some of the participants were concerned that there had been an absence of specific grievances to motivate discontent, beyond longstanding and generalized complaints regarding housing, employment and police brutality. Others were distraught by the disparity between those who seemed to have arrived at Irving Park looking to create trouble, and those who merely got swept up in the crowd's behavior. Reaction to the role of the media was particularly disparaging, as was much of the feedback regarding the preemptive escalation by law enforcement, which many at the meeting thought to have contributed to the tension in the community.

Ultimately, the committee took away three main points:

1) Around seventy-five teenagers had been involved in the disturbances, but none of them had been a worker in a community action war on poverty program.

2) The actions themselves were neither well planned or executed as agitation, and nobody was certain what outside forces were at work.

3) Positive resistance from workers within the community played an integral role in preventing the spreading of the mayhem throughout the area. ${ }^{14}$

Many of the area's youth showed far less interest in reconciliation. As had been the case the day before, Irving Park became a rendezvous point that Monday afternoon for angry and agitated black youth seemingly displeased both by their portrayal throughout the press, which many felt unfairly characterized their behavior as "riots," as well as with the behavior of the police force, whom many felt were arresting bystanders merely because it was easier than rooting out the actual instigators. Those arrested on the Sunday night sweep of Albina cited the epidemic of rioting throughout American cities as 
a predominant reason for Portland's own troubles. "The riot spirit is catching," one young man noted. "As long as there are riots and trouble in other cities, there will be riots here. I know it's not going to do anyone any good ... but there's nothing I can do about that." Others arrested on Sunday night cited the police as both agitating the behavior of the crowd with unwarranted arrests while at the same time taming a situation that would have exploded without them: "If you didn't have those police over there, things would be a lot worse," one detainee declared. "The police are keeping the lid on." Another went as far as drawing a distinction between white and black cops. "White cops are better than black in a deal like this. Crowds go for Negro police," he observed. "How would you like one of your own carrying a gun against you?"15

The first signs of disorder on that Monday occurred around 4:30 in the afternoon when a bottle, stuffed with a gasoline soaked rag, was set on fire and thrown into a pile of tires at a service station along Union Avenue. Police who had been monitoring the incremental gathering of young blacks around N.E. 7th and Fremont descended upon Irving Park, where a group was throwing rocks and glass bottles at the windows of passing vehicles. Determining the situation unsafe following head wounds to three individuals, including an eighteen month old child, the police set up a traffic barricade at the entrance of Union Avenue and Fremont Street. Over the next few hours, as the large group of youths continued to drift between Irving Park and the barricaded intersection nearly two blocks away, police periodically intervened as police cars and area homes became the targets of rocks and bottles. 
Few arrests resulted until nearly 8 p.m., when Mayor Schrunk ordered police to clear Irving Park of all patrons and to "start making plenty of arrests" for disorderly conduct. ${ }^{16}$ Brandishing rifles and shotguns, nearly one-hundred fifty members of the police, backed up by three eighteen man tactical operations platoons specializing in riot control, immediately moved toward Irving Park. Dispersing the crowd of nearly eighty, the officers arrested several alleged instigators of the rock throwing near Irving Park and the fire bombings along Union Avenue. By midnight, nearly seven hours after the initial outbreak, police officials reported the situation to be calm and under control. The night's tally ultimately included sixty eight individuals arrested and thirteen fire calls, ten of which were classified as arson. ${ }^{17}$

Response to Albina's second night of "rowdyism" once again came down predominantly in support of local police and government officials, and in opposition to individuals both directly and indirectly involved in the disorder. Both blacks and whites living in and around the Albina area continued to vocalize abhorrence for the violence in the community. Op-Eds throughout local newspapers over the following days spoke of the need to continue the positive dialogue between blacks and whites in hopes of sparing Portland a major racial riot in the future; others commended the police for their patience and highly professionalized manner. Many letters written to the Mayor and Chief of Police from local businesses and organizations such as the Oregon Liquor Commission, the Irvington Community Association, and Pacific Bell lauded the role of local law enforcement. Other letters from individual citizens, while often praising both McNamara 
and Police Inspector Springer, insinuated that Portland would have confronted a dire situation both in damage to property and race relations, had things been handled differently. A KPOJ radio editorial on the disturbances from August 3 was unapologetically supportive, editorializing that "the fact that the damages have been minimal and injuries only slight reflects directly upon the effective leadership of the Albina Community and upon the competency and efficiency of our government agencies."

Despite these votes of confidence, Mayor Schrunk found himself on the defensive among some critics who saw his response as either too accommodating to destructive behavior or lacking alternative and productive remedies. One correspondent, Bibiana Maher, saw the Schrunk-McCall statement on the failed school levies as so outrageous that she questioned whether the mayor had been misquoted. "If a canvas were to be made of those arrested, the percentage of dropouts would be high," she chastised. "And no amount appropriations could counteract their inclinations to riot."19 Another woman, feeling as though the city and state politicians had coddled and enabled the blacks of the city, wrote that "it was high time that the politicians stopped shelling out the taxpayers [sic] money trying to help the negros [sic], when they would be better off earning their own way and their own jobs and shaping their own future. ${ }^{20}$ Still another found it ominous that the worst riots had occurred in the most 'advanced' cities in the north, not in South Carolina or Mississippi. 
Some correspondents wrote that damages around Irving Park were exacerbated by the police force's lack of a militaristic approach while others opined on the penalties that should face those convicted of vandalism and assault. Someone even provided the mayor the name and address of an individual who had been involved in the disturbances but had not been caught. Others offered alternative ways to help blacks extract themselves from cycles of poverty and unemployment. One correspondent hope Portlanders would "stand behind our police force and maintain law and order - but at the same time act to create more schools, hospitals, housing, and jobs." ${ }^{21}$ Another, a white man teaching in a Model Cities school, contrasted older African-Americans who tended to be "docile and content, and sensible in handling these racial problems" with "youth who are feeling lost and frustrated, filled with energy with little opportunity to give it release," people he described with "little to lose as they see it."22

By the second night of chaos, reaction from the public had become much more vitriolic. In a letter to Mayor Schrunk dated August 1, Portland resident Margaret Luyben proposed that the mayor make an announcement that the police shoot any of the "militant black negroes" who are seen to be looting or destroying property. ${ }^{23}$ A local radio editorial blamed the week's "hell raising" on a group of "hoodlum elements" who expected that they "should be handed something rather than working for it." As had been the trend nationally, levels of suspicion and anger toward racial agitation and discord seemed to increase with the frequency of the disruptions. ${ }^{24}$ Many city residents blamed the disturbances on outside agitators as opposed to local black youth. Despite the 
absence of evidence to support it, such sentiments were also voiced by both Mayor Terry Schrunk and Police Chief Donald McNamara who, having searched 450 cars between late Monday evening and early Tuesday morning, declared that whatever agitators had instigated Albina's racial strife the previous two nights no longer were in the city. Arrested youths, interviewed by reporters the following day, echoed similar statements, saying that any Black Power elements who had started the disturbances were already gone.

Letters to the mayor written in the days following the riots frequently spoke of outside individuals. Clifford Daniels, a black man who had lived in Albina for fifty three years, protested that "The people of Albina do not want any trouble and are not going along with outside agitators, although they may come in here and get some of these punk hoodlums to follow them." 25 An Op-Ed in the Oregon Journal titled "Portland's Turn on the Riot Scene" stated that "what is striking about about the relatively small amount of arson and window-smashing by hoodlums which took place in Portland Sunday and Monday nights is that it appears to have been triggered by agitators." ${ }^{26}$ Speculation over the role of outside agitators in the Albina disturbances were given additional credence when it was reported in an August 1 newspaper article that a train load of thirty blacks had been sent to arrive in Portland from California that Monday night to help foster additional trouble. When the train arrived, Portland police, augmented by railroad detectives, were able to capture four of the individuals, three blacks and one white, while twenty others fled the premises. Despite the protestations of the individuals that they had 
legitimate business in Portland, the Oregon Journal's article detailing the supposed plot reinforced existing beliefs of the presence of outside agitators. ${ }^{27}$

Panic over outside agitators received confirmation for some Oregonians at a Monday night speech by Lola Belle Holmes, a former African-American communist and undercover FBI agent. Sponsored by a group called TACT (Truth About Civil Turmoil), and speaking to an overflow crowd at a high school in suburban Hillsboro, Holmes stated that the riots spreading throughout American cities, including Portland, were largely communist instigated and encouraged. Denouncing civil rights leaders such as Martin Luther King, Jr. and SNCC Chair Stokely Carmichael as "dupes" of the Communist Party, Hill detailed the conspiracy that enveloped Portland and other cities plagued by unrest. The civil rights movement "gives the impression that it is a champion of Negroes, in order to use them for the attack upon our country - with Negroes on the front line," she proclaimed. "You witnessed in your own city one of these attacks." 28

In contrast to such assertions, Lorenz Schultz, a pastor at a Methodist Church in the area, argued that the role of any outside agitator should be downplayed, given that such explosive behavior within the community could not have been exploited by outsiders, if that was truly what had occurred, without the presence of already existing racial tension. ${ }^{29}$ Indeed, little to no evidence supported the case for outside intervention. FBI agent John H. Williams reported that Monday that despite checking out reports and claims that professional agitators had been brought to Portland to instigate rioting, nothing supporting such a theory had been confirmed. ${ }^{30}$ Six young blacks who had been 
arrested in the Monday night disturbances and interviewed by Oregonian reporter Peter Tugman, despite believing that outside instigators had orchestrated the turmoil, were unable to identify any of them, relate any of what they had said, or accurately state where such individuals had come from. ${ }^{31}$ On Tuesday, Lieutenant Jack Crawford of the Intelligence squad of the Portland Police Department, said that while they had been hunting down the "outside agitator" rumors, "We can't verify them and we have no real evidence that outsiders are responsible for what has been going on the last two nights." In contrast, Crawford described the Irving Park incident as "a fairly organic disturbance" attributed to local youth. ${ }^{32}$ That same day, J. Edgar Hoover, director of the FBI, told President Lyndon Johnson's advisory committee on racial disorders that neither he, nor any other individual within the agency, possessed intelligence regarding an orchestrated conspiracy behind the fifty two racial disorders that had occurred throughout the country the previous three years. ${ }^{33}$

Whether the public disorders on July 30 and July 31 had been instigated by outside elements or were simply the manifestation of festering strains in the community, the incident enabled a few black youths the opportunity to voice their grievances both to church ministers throughout the Albina district as well as city officials. Responding to the complaints of inadequate housing, job shortages, and park recreation among black youths in the community, Mayor Schrunk attended an August $2^{\text {nd }}$ with nearly twenty young people where he assured attendees that city government would do everything in its power to assist the neighborhood. "There certainly are some pretty old houses over 
there," he commented. Schrunk then heard a volley of complaints concerning the prevalence of rodents, inadequate garbage pickup, and inequalities in the hiring process of black park employees. ${ }^{34}$ Joined by City Commissioner Frank Ivancie and Russell Peyton, a member of the city's Human Relations Committee, the mayor promised to assist in finding solutions yet he also said he could not make promises such as immediately withdrawing the police contingent from Albina or revising the district's school curricula that he could not keep.

To many of present at the meeting, the exchange left them frustrated suggesting that the mayor did not understand the underlying problems plaguing the community. "Nobody ever listened to these kids," stated an Albina social worker present at the meeting. "Not their parents, not their ministers, and least of all the people who keep promising that if we work together, thing will be better." ${ }^{35}$ Many criticized Schrunk's apparent disinterest in the area, citing the fact that he had rarely visited Albina, repeatedly sending aides and staff members to carry out any business his presence would have necessitated. "What is Albina, a foreign country?" one youth responded. ${ }^{36}$ Additionally, several people complained that many of the jobs for which blacks in Albina were qualified and routinely applied for, such as maintenance positions at local recreation centers and parks, as well as manual labor and construction jobs throughout the neighborhood, were never given to them. Oliver O'Ferrell, a twenty year old Albina resident, spoke to this disparity. "There are no Negroes employed on the park's maintenance staff," he pointed out. "Right here in our own neighborhood, white people 
have all of the jobs." Other issues of contention included the police presence throughout Albina, the blight of decrepit and decaying homes throughout the neighborhood, and the stereotypical portrayals of African-Americans throughout the Portland Public School textbooks and curriculum. Community members "have been trying to say something," an unidentified speaker complained. "Nobody wanted to listen. They've been going around in circles. ${ }^{37}$ The complaint seemed to be borne out at meetings later in the day between Albina residents and Frank Ivancie, when the parks commissioner found "no basis" for the charge that African-Americans were excluded from employment in the neighborhood city parks. ${ }^{38}$

As the Albina community returned to a sense of normalcy, fears of additional violence and a full-fledged riot subsided. A fire-bombing at a fuel company on Tuesday night, along with the arrests of ten adults and fifteen juveniles - six for possessing fire bombs - while initially precipitating concern, produced no new outbreak of violence as the police resumed on heightened alert. By mid-day Wednesday, however, police presence in the community had been reduced in size and officers previously forced to work twelve-hour days began to return to routine eight-hour work schedules. Wednesday also brought the first day of arraignments for many of the suspects arrested over the previous two days. Because most centered on disorderly conduct, nearly all the individuals arraigned were given sixty-day jail sentences for their roles in the three days of disturbances. Judge Phillip Abraham commented that "it appears that all of those arrested during the Albina disturbances have extensive criminal records," furthering 
cementing police insistence that nearly all of those deemed worthy of arrest had been the leaders and main contributors to the turmoil. At the same time, the mayor's office ignored calls to close Irving Park for an unspecified amount of time and instead deferred to the sentiments of the residents of the black community, who argued that keeping the park open might better the standing of city officials in the eyes of the local people. "As long as things remain quiet in the district, it is important that we pull our police out of there," one resident explained. "Law abiding people shouldn't have police around them wherever they go."39

To some extent, the disturbances that occurred in the Albina district between July 30th and August 1st were not only a racial problem, but a youth problem. Albina's small population of young, angry, and restless agitators, seeking an outlet and a way to lash out, could likely have been found in every neighborhood of every city around the country. Vocal displeasure over a lack of neighborhood public parks and recreation areas, job opportunities, and employment training were not problems that were unique to Albina, or even black communities in general. Race, while certainly a factor in the Albina disturbances, was not, in and of itself, the only cause. Of the 430 youths enrolled in the in-school Neighborhood Youth Corps, a program that gave part-time and summer employment to youths from low-income families to enable them to continue their education, and of which many were black, only four had been arrested in the disturbances. ${ }^{40}$ 
Such facts as these indicate that race, while certainly a factor in unrest, was not as powerful a motivator as that of poverty. In many cases, older, wealthier, and more established blacks throughout Albina found themselves in an alliance with whites regarding younger blacks who participated in the violence. There was not a monolithic response to the disturbances by either the black or white community, partially as a result of age and socioeconomic differences, but also because, as stated by numerous members of both the press and the black community, there were no explicit grievances voiced by those who participated in the turmoil. One Albina teen-ager held at a juvenile detention center following Sunday's disorder, argued that much of the discord in black communities throughout America, including Portland, was a result of the knowledge that large scale rioting, such as that which had occurred in the Watts section of Los Angeles two years earlier, led blacks to feel empowered: “There wouldn't be any riot here ... and there wouldn't have been any riot in Detroit ... if there hadn't been a riot before it somewhere else. ${ }^{, 41}$

Such statements give credence to arguments that what occurred in and around Irving Park, while indirectly fueled by anger over issues of employment, housing, parks, and education, may, instead, have been an organic part of a spreading epidemic of rioting occurring throughout urban areas in the late-1960s. Portions of Albina's black youth community certainly sought to pressure city government officials to improve upon the social and economic issues plaguing their neighborhood. Yet those who participated in the Irving Park disturbances likely did so not to address those issues as to seek an outlet 
to express dissatisfaction with the inability to resolve them. While symbolizing defiance in the face of authority, the disturbances lacked any clear or unifying goal, a fact that ultimately stifled major reforms in the immediate wake of the unrest.

${ }^{1}$ Stan Federman, “Albina Adults Deplore Strife, Help Police Rout Gangs,” Oregonian, July 31, 1967, 6M 14.

${ }^{2}$ J.D. Millner, letter to Terry Schrunk, July 31, 1967, City of Portland, Schrunk papers, Stanley Parr Archival and Record Center, Portland City Archives, AF/167044, A 2011-002.

${ }^{3}$ Katharine T. Noyes, letter to Terry Schrunk, July 31, 1967, City of Portland, Schrunk papers, Stanley Parr Archival and Record Center, Portland City Archives, AF/167044, A 2011-002.

${ }^{4}$ William Sanderson, "Bitter, Frank, Articulate Youth of Albina Speaks Up," Oregonian, August 6, 1968, $6 \mathrm{M} 4 \mathrm{~J}$.

${ }^{5}$ Colden Brown, Jr., "Rapping About Albina," Vanguard, September 27, 1967, 10.

${ }^{6}$ Ibid.

${ }^{7}$ Sanderson, "Bitter, Frank, Articulate Youth of Albina Speaks Up," 6M 4J.

${ }^{8}$ Brown, Jr., "Rapping About Albina."

${ }^{9}$ Bob Olds, "Police Put in 'Tough Night,' Don’t Expect More Violence," Oregon Journal, July 31, 1967, J5.

${ }^{10}$ Andrew Mershon, "Partial Blame Placed on School Levy Loss," Oregonian, August 1, 1967, 16 6M.

${ }^{11}$ Ibid.

${ }^{12}$ Doug Porter, "Discontent of Portland's Negroes Laid to Unemployment," Oregon Journal, August 1, 1967, J7.

${ }^{13}$ Ibid.

${ }^{14}$ Richard Floyd, "Metropolitan Steering Group Explore Unrest Cause," Oregonian, August 1, 1967, 6M 16.

${ }^{15}$ Judd Smith, "Negro Youths Trace Albina Unrest to Racial Warfare in Other Cities."

${ }_{16}^{16}$ John Guernsey, "Rowdies Dispersed at Park," Oregonian, August 1, 1967, 1.

17 “13 Fires Ignited By Gangs," Oregon Journal, August 1, 1967, 1.

${ }^{18}$ KPOJ Editorial staff, letter to Terry Schrunk, August 3, 1967, City of Portland, Schrunk papers, Stanley Parr Archival and Record Center, Portland City Archives, AF/167044, A 2011-002.

${ }^{19}$ Bibiana Maher, letter to Terry Schrunk, August 1, 1967, City of Portland, Schrunk papers, Stanley Parr Archival and Record Center, Portland City Archives, AF/167044, A 2011-002.

${ }^{20}$ Anonymous letter to Terry Schrunk, August 4, 1967, City of Portland, Schrunk papers, Stanley Parr Archival and Record Center, Portland City Archives, AF/167044, A 2011-002.

${ }^{21}$ H.D. Smith, letter to Terry Schrunk, August 4, 1967, City of Portland, Schrunk papers, Stanley Parr Archival and Record Center, Portland City Archives, AF/167044, A 2011-002.

${ }^{22}$ H. Eugene Kirchner, letter to Terry Schrunk, August 6, 1967, City of Portland, Schrunk papers, Stanley Parr Archival and Record Center, Portland City Archives, AF/167044, A 2011-002.

${ }^{23}$ Margaret Luyben, letter to Terry Schrunk, August 1, 1967, City of Portland, Schrunk papers, Stanley Parr Archival and Record Center, Portland City Archives, AF/167044, A 2011-002.

${ }^{24}$ KPOJ Editorial staff, letter to Terry Schrunk.

${ }^{25}$ Clifford Daniels, letter to Terry Schrunk, August 1, 1967, City of Portland, Schrunk papers, Stanley Parr Archival and Record Center, Portland City Archives, AF/167044, A 2011-002.

${ }^{26}$ Editorial, "Portland's Turn on the Riot Scene," Oregon Journal, 1 August 1967, 17.

27 “4 'Rail Rider' Get Jail Terms," Oregon Journal, August 1, 1967, 1. 
28 "Negro Former FBI Undercover Agent Blames Communists For Racial Strife," Oregonian, August 2, 1967, 4M 17.

${ }^{29}$ Lorena Schultz, letter to Terry Schrunk, August 1, 1967, City of Portland, Schrunk papers, Stanley Parr Archival and Record Center, Portland City Archives, AF/167044, A 2011-002.

30 "FBI Hunts Agitators of Turmoil," Oregon Journal, August 1, 1967, 1.

${ }^{31}$ Peter Tugman, "Six Talkative Negro Prisoners Voice Resentment of City Police," Oregonian, August 2, 1967, 6M 15.

${ }^{32}$ Stan Federman, "Police Fail to Confirm 'Outside Agitator' Rumor," Oregonian, August 2, 1967, 6M 15.

33 "Hoover Tells Panel No Conspiracy Seen," Oregonian, August 2, 1967, 6M 15.

${ }^{34}$ William Sanderson, "Negro Youths Fear Mayor 'Missed Message' of City Hall Discussion," Oregonian, August 2, 1967, 6M 15.

${ }^{35}$ Sanderson, "Bitter, Frank, Articulate Youth of Albina Speaks Up," 6M 4J.

${ }^{36}$ Ibid.

${ }^{37}$ Ibid.

38 "Parks Chief Ivancie Talks to Albina People, Declares Door Open for Recreation Ideas," Oregonian, August 3, 1967, 5M 13.

${ }^{39}$ Robert Olmos, "Peace Returns After 2 Nights of Disorder," Oregonian, August 2, 1967, 1.

40 "Employed Youth Shun Trouble, Oregon Journal, August 3, 1967, 5M 6J.

${ }^{41}$ Smith, "Negro Youths Trace Albina Unrest to Racial Warfare in Other Cities." 


\section{Chapter 3: Changing the Status Quo (1968)}

To some in Portland, the sole positive outcome of violence in Albina was the emergence of new lines of communication that were developing between the white and black communities. In the aftermath of the unrest at Irving Park, various efforts, some pragmatic and others more symbolic, were undertaken by city officials and AfricanAmerican advocacy organizations to reduce the likelihood of future racial turbulence.

In a pragmatic vein, and seeking to appease critics of the police who sought greater civilian oversight of law enforcement, Portland Chief of Police Donald McNamara established a Police Community Relations Unit that would be aimed at improving the "communication and relationships between police and Albina residents."1 In a similar capacity, Mayor Terry Schrunk and other city officials sought to amend policies and ordinances that had proved inadequate in the immediacy of the disturbances. Measures which had not adequately addressed what did and did not constitute a city emergency were tightened up to reflect growing unease concerning urban unrest. Ordinances concerning the constitution and use of explosives and firebombs, for example, now were explicitly defined in regard to the composition and use of such devices. $^{2}$

Having cited irresponsible news media coverage of the disturbances as a major contributing factor to Portland's turmoil, the city government drafted a "City Code for the Reporting of Civil Disorders."3 Created and written for the benefit of the city's news outlets, the document listed fourteen separate goals for reporters regarding how the dissemination of information in similar future conflicts should be handled. These 
included the nuanced ("Seek to use official designation in describing incident. If police call it a disturbance ... we should not label it a riot"), the politically beneficial ("Scare headlines, scare bulletins and sensationalism of any kind must be avoided"), and the sensible ("The potential for inciting public disorder demands that COMPETITION be secondary to the cause of PUBLIC SAFETY. Be governed by rules of caution, good taste, and COMMON SENSE.") $)^{4}$

As minor bureaucratic changes such as these began to be implemented, Mayor Schrunk's administration initiated its own critical assessment of Portland's racial situation, as well as the changes and reforms necessary to improve it. Responding to a November 1967 Boston University Political Science research project concerning problems facing inter-racial relationships throughout the nation, Schrunk's administrative assistant, Keith L. Jones, acknowledged that a lack of both quality housing and minority employment, partially as a result of a lack of opportunities stemming from racial prejudice, played a key role. To the question "What can government do to foster interracial harmony?" Jones pointed to Portland's Head Start program, along with the city's application to the federal government for Model Cities funding, as commendable efforts to improve the racial divide. At the same time, Schrunk's response to the Boston University survey noted "the lack of understanding of culture which promotes suspicion and frustration, particularly within the minority groups, and the resistance to change on the part of the majority so as to frustrate those persons who have been disadvantaged by virtue of race within the mainstream of our social and economic climate." "It has been suggested by some students of the minority race" the mayor added, "that the so-called 
power structure responds only to crisis situations which result in change to accommodate persons of other races and creeds." 6

Schrunk's candid assessment was likely the result of his embattled relationship with more conservative members of Portland's white community who, despite the mayor's nuanced and nearly universally lauded handling of previous racial conflagrations, refused to relent in their attacks on his leadership. While many in the white community worked towards inter-racial compromises on contentious issues, others were unceasing in their views. In correspondence from constituents in the months following the disturbances, there were still very clear signs of hostility toward Albina's black community. Referring to the area's African-Americans as "gang bangers," Nellie Mitchell urged the mayor to "do something," unless he wanted such turmoil to occur again. $^{7}$ Another citizen, citing an Oregon Journal article covering a speech given by black power activists, blamed the mayor for Portland's "radical problem," and concluded that he had recently purchased two guns for his own safety. ${ }^{8}$ Despite such animosities, city officials acknowledged that Portland had been negligent in its commitment to minority citizens regarding implementation and enforcement of non-discrimination laws.

In the months following the Albina disturbances, city government officials drafted a list of suggestions for the city to improve non-discrimination policies towards minority populations. The document began with three questions: "Does City government have an explicit non-discrimination policy on hiring and upgrading? Is it written, posted, [and] repeated at intervals? Does everyone understand that city government is serious about this policy at every level in all operations?" It then offered ten pieces of advice that focused on efforts to implement and enforce periodic reviews of such policies; the 
overt publicizing of non-discrimination efforts; attempts to integrate greater numbers of minority employees into the city's decision-making process; and a reaffirmation of the city's commitment to non-discrimination in contract bidding."9

Outside of government, efforts to improve race relations in the city centered on the Urban League, which held its 1967 national convention in Portland within a month of the disturbances. Founded in 1945, Portland's branch of the Urban League worked to provide opportunities in housing, education, and employment for African-Americans who had predominantly moved to Portland during World War II to work in the Kaiser Shipyards. When many of these African-Americans chose to stay in Portland following the conclusion of the war, the Urban League, which had originally been brought to Portland to convince the city's blacks to leave, went to work attempting to integrate a city with a strong history of racism and prejudice.

Entitled "People v. the City: Opportunity and Challenge," the Urban League's 1967 conference initiated a program called "Operation Dialogue.” Through this initiative, Urban League staff members spoke to nearly 5,000 parishioners in thirty-seven churches throughout the community on the Sunday of their convention. In the interest of maintaining order and preventing clashes between youth and the police, the organization cooperated with community leaders, city agencies, police, and neighborhood people in mounting a series of spring meetings to find solutions to problems centered in the neighborhood. ${ }^{10}$

In a similar vein, C-CAP (Church-Community Action Program), which had worked to improve police-community relations, held a summit in which Portland's black and white church people, clergy, and laymen spoke to community tensions. The group 
hoped to bridge the gap between establishment whites and an increasing number of militant blacks. "If we are to eliminate the explosive violence that makes the headlines and causes people to act irrationally," it declared, "we need to root out the quiet dehumanizing things that happen every day and subject them to the searching light of Christian compassion and Christian action." ${ }^{11}$ C-CAP also used the disturbances to solicit donations to fund summer programs for teenagers, as well as weekend seminars in the Albina district that provided courses on topics such as Black history and the management of race-based confrontation. Calling on African-Americans to become more involved in their community and church and to redirect their anger towards more progressive endeavors, C-CAP stressed the necessity of reducing tension in the community as well as educating citizens about their roles in society. ${ }^{12}$

One major effort by the city at improving race relations was the writing of the 1967 annual report on race relations by Portland's Human Rights Commission (HRC). An interracial collection of eleven members, the Commission had been created by a city ordinance and was tasked both with investigating complaints of racial and religious discrimination, as well as carrying out programs believed to be beneficial in promoting tolerance. ${ }^{13}$ Written near the end of the year, and focusing predominantly on issues of employment, housing, youth, and education, the report of highlighted many issues that played a role in the turmoil months earlier. On the topic of employment, the document stated that while a Task Force of business and labor leaders had been created to educate various industries in the spirit of "affirmative action," there were still problems in Portland. "Disadvantaged minority youth are still not convinced that businesses will hire them ... no matter how well qualified," the report read. "We still have the prevailing 
belief that discrimination per se is operative." ${ }^{\prime 14}$ The next report cited successful efforts by HRC's Housing Committee to break down segregation policies that had existed in the real estate market for years, leading to a number of black families who, without incident, had found homes outside previously segregated residential areas. Nevertheless, the report read, "the overall pattern of resident location still shows resistance to the movement of non-whites into all-white areas.."15

For many, however, it was the HRC's views on police-community relations that were of most interest. Acknowledging that the police were the "most visible arm of the establishment which so many young people are rebelling against," the Commission took seriously the complaints of police mistreatment of minorities. Referencing the summer turmoil between youth and police, the Commission stated that while relations had improved, and the work of the police during the unrest was to be commended, far more could and would have to be done. The report cited the fact that many members of community youth groups had visited the Commission's offices to report complaints of police activity, and that in many cases the allegations were investigated, with the results of the investigations shared with the complainant. Furthermore, the Commission had worked in tandem with the National Conference of Christians and Jews to improve community and police relationships. These steps, carried out by the HRC on behalf of the city, were aimed at helping the community realize its responsibility in solving many of its race-related problems.

Despite efforts to alleviate racial tension, however, there were still underlying currents, particularly among younger African-Americans, concerning dissatisfaction with the role of traditional blacks in the community. While Portland NAACP leader Thomas 
Vickers continued to speak on behalf of Portland's black community in an effort to prod the city to improve the employment, recreation, and housing options for Albina's black citizens, younger activists Colden Brown and Oliver O'Ferrell, participants in the July and August disturbances and members of Portland's burgeoning Black Power movement, saw this solicitation of government programs and funding geared towards racial reconciliation as yet another concession by blacks to a racist white power structure. Expressing frustration with traditional black organizations, Brown asserted that no tangible help had come from the black community for Albina's African-American youths that had been held in jail and tried, many of them for the first time, as a result of their participation at Irving Park.

"Those organizations that are supposed to be doing something for the Black people - the Urban League, NAACP and War on Poverty," charged Brown, "seem more concerned with buying desks, spending a lot of time on the phone, charging their grocery bills to the boss and making surveys to show the white man how much progress is being made." ${ }^{\prime 16}$ Oliver O'Ferrell, referencing a shift in Portland's black leadership from the old guard to a much younger one, decried that traditional black advocacy organizations would no longer speak for all blacks. "Let Tom Vickers [President of the Portland Branch of the NAACP] speak for himself and the NAACP," he stated in an early-August Oregonian article. "I speak for me. You want to find out what I think, ask me, not Tom Vickers." ${ }^{17}$ Other groups such as the Society for New Action Politics (SNAPS), an offshoot of an anti-war organization called the Citizens Coordinating Committee on Vietnam (CCV) that worked towards liberal causes such as Native American fishing rights and grape worker boycotts, insinuated that blacks employed in government social 
agencies such as the War on Poverty's Office of Economic Opportunity were behaving like "Uncle Toms."18

Appropriately, a January 1968 Oregonian article titled "Study Shows Portland Could Explode," pointed to generally younger, less-established black youths with radical views regarding social equality and integration as "new voices" of the black community that had supplanted the traditional African-American spokesmen of the NAACP and Urban League. The feature used a study by Professor John C. Maloney, the acting research director of Northwestern University's Urban Journalism Center, to suggest Portland ranked $21^{\text {st }}$ on a list of "cities most likely to experience racial strife during the 1968 summer months." Portland's black demographics (a substantial African-American growth rate in a small geographic area) and geography (the covert racism of the North, as opposed to the overt racism of the South), had prompted Maloney to rank it rank it as the third most likely of all cities west of the Rocky Mountains to see a riot in the summer of 1968. $^{19}$

Despite the surprise many Oregonian readers may have had as a result of Maloney's research, the possibility of additional racial turmoil in Portland had always been seen as likely. The Human Relations Committee, which had published an annual retrospective of its goals and successes concerning racial discrimination near the end of 1967, followed up that January with a report looking ahead to the racial challenges of the upcoming year. Although the previous summer's disturbances had not reached riot proportions, the document asserted, underlying causes and frustrations remained and Portland "might not be as fortunate again."20 "Only the complete removal of race discrimination from our community can bring about peace and harmony between all 
groups," it concluded. ${ }^{21}$ Such concerns led the Oregon Advance-Times, a black-owned Portland newspaper that ran from February to November of 1968, to survey Portlanders on the question of whether the city would experience race riots during the coming summer, with many respondents answering in the affirmative. ${ }^{22}$

Eschewing the political talking points often utilized by politicians on the subject of racial inequality, the HRC report served as a broadside to Portland's deeply entrenched racial prejudices. It acknowledged not only that many legal and civil rights victories on behalf of minorities had actually made little difference in everyday lives, but also that it was a result of "apathy and a tradition of discrimination," that such intransigence had persisted. ${ }^{23}$ The document also spoke to the way de facto segregation in housing and schools denied true participation in the community, providing only "theoretical guarantees" of equality. ${ }^{24}$ In confronting the always fragile issue of police-community relations, the report was no less straightforward. Stating "the police officer generally represents the authority to maintain the status quo" and that "he thus becomes the logical target for those who desire a change," the HRC suggested that an improvement in policecommunity relations was essential to bring about change in a society that had been "infected with racial prejudice." 25 "This racial prejudice is now being reflected in the police establishment," the report argued. "The community uses the police to impose a value system that is often repugnant to minority group members." ${ }^{26}$ All efforts to challenge the status quo, reform current laws, or change internal power structures, the report concluded, would lack any tangible success until the basic issue of prejudice had been eradicated. 
Despite such negative assessments, efforts at equalizing employment opportunities for African-Americans within city government continued to take place. Citing a statistic indicating that only eight of the city's 1,300 fire fighters and police officers were black, the State Employment Service of North Portland began efforts to recruit and hire greater numbers of African-Americans to participate in those specific positions in February 1968. Acknowledging that many potential black applicants likely refrained from applying for such positions as a result of past minor offenses and misdemeanors, the State Employment Service overturned its previous requirement necessitating a pristine past police record for all applicants, and encouraged all AfricanAmericans interested in such positions to apply. "There is a tremendous need for Albina community men to serve in the fire and police departments," stated the Oregon AdvanceTimes. “The city's excuse has been that 'Negroes just don't apply.' There is no need for this [now]."

Much as the disturbances within the Albina district had forced Portland to acknowledge its own complex relationships concerning race, the March 1968 release of a report by President Johnson's Advisory Commission on Civil Disorders, otherwise known as the Kerner Commission Report, did much of the same. Appointed by the president following the rioting in Newark, Detroit, and other cities in the summer of 1967, the Kerner Commission sought to study the urban racial problems throughout the country that had led to such unrest. Citing numerous reasons for the disharmony present throughout many American cities, the Report focused on three key causes: the economic marginalization of inner-city African-Americans; institutional racism in areas of 
employment, housing, and education; and social alienation, particularly as it was present in the racial isolation of minorities in their schooling.

In Portland, the findings were read with a mixture of interest and skepticism. The opening lines to an Oregonian article titled "Race Report Greeted by Enthusiasm, Hope, Plus Skepticism on Pertinence to Portland" set the tone. "It sounds great on paper," "it could change the precarious destiny of America," and "just words from another committee in Washington" represented the range of anonymous responses by Portland's black community members. ${ }^{28}$ Portland's leading officials replicated the response they had delivered during the Albina disturbances by attempting to downplay the report's findings, disconnecting the Kerner Commission conclusions from Portland's own racial issues. Despite learning in a memo nearly a month earlier "that some of our thinking on our own local problems are not far out of line with the thinking of the Advisory Committee," Mayor Schrunk backed away from tying Portland to the racism detailed in the report. "I don't identify our problems in race relations in Portland with those cited by the commission, but I think we should study the report with open minds in hopes of finding recommendations that would be applicable to our problems," he declared shortly after the report's publication. ${ }^{29}$ Chief of Police McNamara, echoing Schrunk's skepticism, was hesitant to connect the Kerner Report's findings to Portland's own racial problems. "If the proposed jobs for unemployed Negroes are simply governmental make-work positions on a city, county, state or federal payroll," warned McNamara, "they may likely engender only more bitterness - the opposite intended effect." ${ }^{30}$ Going even further, the police chief suggested that white leaders and the city's black population might best be served in "unobtrusive quietness." ${ }^{31}$ Less prominent city officials such as 
Isadore Maney, who served as the manager of the State Department of Employment's Albina office, saw other benefits to the report, stating that while the recommendations and suggested implementations it included were not likely to be funded, the message the report contained was much more powerful. "I understand the scare tactics used by the commission and maybe they'll do some good in shaking Portland out of its lethargic state," declared Maney. "Sometimes if a fellow hollers long enough, the right ears hear the message. ${ }^{32}$

Among community activists, the report was largely seen as satisfying, providing credence and validation to the argument that institutional racism was endemic to Portland and other cities. Rev. Paul Schulze, a founder of C-Cap, and long-time city activist, seemingly gratified by the commission's findings, asked if the white community had "the strength to accept the report and respond effectively" or whether it would take "some more prodding, some more burning?" ${ }^{33}$ E. Shelton Hill, Executive Director of Portland's Urban League, referencing the report's comparison of race relations in urban American to that of South African apartheid, warned that should activists and citizens in Portland not follow through on its recommendations, they would face "a very tragic situation, and probably one of the most crucial in our history." ${ }^{34}$ An Op-Ed in the Oregon AdvanceTimes was even blunter. "We hope our own mayor will review this report and will be among those mayors that are tuned in and recognizing a problem that exists that calls for immediate action to wipe out the cause - the cause being white racism," the editors declared. ${ }^{35}$

The assassination of Martin Luther King, Jr. in Memphis, Tennessee on April 4, 1968 at the hands of James Earl Ray, a southern white supremacist, precipitated 
immediate rioting in over forty major American cities, leading to over twenty fatalities. ${ }^{36}$ While Portland did not experience any of the large-scale disturbances that afflicted other urban centers, King's murder played a prominent role in reigniting much of the anger and bitterness seemingly suppressed since the outbreaks of the previous summer. The assassination also fueled a renewed and furious debate over the role that violence could, and should, play within the black community.

Anticipating the likelihood that the devastation of King's assassination might trigger violence throughout Portland, many state and city civic leaders worked to diffuse the situation. Urging non-violence, Governor Tom McCall pleaded that Portlanders look to King's martyrdom as an adherent of non-violence "in the long hot summer ahead." Mayor Schrunk, articulating a desire for blacks and whites to recommit themselves to racial reconciliation, expressed a hope that anger would not be poorly directed. "I would hope that people of all races would recognize this as an act of violence that cannot be tolerated in this nation and that black and white citizens will not use this tragedy as an excuse for additional acts of violence," he declared. ${ }^{38}$ Rev. Schulze, in contrast, took a more militant position. Schulze insisted that King's assassination reflected a "sickness" inherent in the separated societies America was building. "If we continue to resist the efforts of the black people to claim their stake in our land," he warned, "we will be headed for self-destruction as a nation., ${ }^{39}$ Mayfield Webb, executive director of Portland's Metropolitan Steering Committee, also lamented America's violent reputation. "I wonder what we must look like to other nations with our habit of killing off this sort of man," he mourned. "As the nonviolent voices are stilled again and again are they not opening the door to other voices," asked Webb? ${ }^{40}$ 
The immediate reaction of Portland African-American leaders such as Webb to King's death was anguish, as well as a renewed dedication to equality and harmony. Thomas Vickers proposed expediting and reigniting efforts to increase black employment to "alleviate racial tensions and strife" that otherwise might simply be used to "suppress disturbances. ${ }^{, 41}$ Rozell Gilmore of the Albina Neighborhood Service Center was somewhat blunter. "The possibility of violence has increased tremendously," he implied. "King was the one man who could have calmed this country down this summer." Jimmy Walker, the editor of the Portland Clarion-Defender, another of Portland's black newspapers, warned against violence in and from the black community, advocating continued non-violence to achieve goals of equality. "Forgive the white race for the unjust things they have done to us in the past," Walker wrote in an editorial commemorating King, "and work to fulfill Dr. King's wishes by gaining our just place in society, by taking advantage of the schools and opportunity available to everyone. ${ }^{, 43} \mathrm{E}$. Sheldon Hill, a friend of King's who had brought the civil rights leader to Portland to speak in 1961, simply said the nation would never again be the same as a result of King's work. ${ }^{44}$ By nearly all accounts, the positive steps that had been made between blacks and whites in Portland in the months following the Albina disturbances or, at the very least, the tacit agreement to submerge their greatest grievances, had, in the wake of the tragedy, been eviscerated.

A group of clergymen, led by Rabbi Emanuel Rose of Temple Beth Israel, distressed by the possibility of civic deterioration, attempted to use their stature as religious leaders to bring about positive change. Pressuring Mayor Schrunk to use King's Sunday memorial service for a much more forceful statement on the problematic racial 
issues in Portland than in the past, the leaders urged the mayor to show the community that the city would provide leadership to help solve the racial problems created by white society. ${ }^{45}$ Rose stressed that opportunities were needed to educate a white community who failed to even recognize that problems ever existed. ${ }^{46}$ Rev. John H. Jackson, an African-American minister from Mt. Olivet Baptist Church, perceiving that the mood of the city was ripe with "unity and Christian relationship," suggested that the mayor capitalize on the "conscience stricken" whites in Portland by giving a speech recommitting the city to achieving further black gains in jobs, housing, and education. ${ }^{47}$

The clearest divide over how to once again proceed toward efforts of racial reconciliation occurred within the younger demographics of the city's African-American population. Many younger residents living in the the Albina community, as well as emerging black militants aggrieved by King's killing, responded with inflamed rhetoric and hostility. Tom Wilson, an employment counselor at the Albina Neighborhood Service Center, predicted violence as retaliation for King's death: "This is the spark that will set America on fire like a box of matches ... The black man will not stand still and be shot like pigs in a pig pen ... I don't believe in violence, but I believe in meeting force with force. ${ }^{\natural 8}$ Dennis Payne, president of the Black Student Union at Portland Community College, read a statement claiming to represent the views of the United Black Front of Portland, a coalition of twenty-one black organizations. African-Americans must "never look back, never stop, and never worry" in their "struggle for and to gain the freedoms, the rights, and the justice that our black brother Martin Luther King died for," by "any means necessary," the statement declared. ${ }^{49}$ Frank Fair, who convened the press conference, spoke tersely and combatively to questioning members of the white press, 
before asking all non-black reporters and observers to leave the room. When only a black television commentator, a black radio reporter, and the publisher of a Negro weekly newspaper remained, Fair continued the press conference. ${ }^{50}$

Despite such predictions of violence and heightened racial antagonism following King's death, the only immediate indications of strife in the city occurred at Jefferson High School, an Albina area school in which nearly forty percent of the 1,700 students were African-American. ${ }^{51}$ Given the substantially large number of black students at Jefferson, racial discord had become somewhat commonplace between both teachers and students in the years and months leading to King's death. An Oregon Advance-Times article nearly two months before the assassination titled, "The Problems at Jefferson High; What are the Answers?" spoke to burgeoning tensions between two black members of the student body and their predominantly white school administration. Focusing on the legitimacy of Black Student Unions in a high school, the role of African-American history in the curriculum, and the perception of racial inequities in school discipline, the article illuminated many of the same strains occurring throughout society at-large. An Op-Ed in the Oregon Advance-Times by a Jefferson High School senior in February of 1968 was particularly tough on the school's administration, stating that "certain members of the faculty and staff at Jefferson are undermining and destroying the very values and qualities that high school are supposed to be developing." 52 Rather than providing and educating the student for the future, the reader saw the role of the administrator as causing far greater harm than good. "They destroy ideals, stifle creativity, frustrate ambition, and make human relations difficult, if not impossible," the protestor declared. ${ }^{53}$ 
Despite the symbolic flying of the flag at half mast outside the school to honor King's commitment to nonviolent unity, many of the students inside Jefferson embodied the resentment and hostility felt in the immediate aftermath of the tragedy. Having anticipated the possibility of trouble throughout the school day, administrators had increased the number of police in an effort to deter possible unrest. Despite this precaution, however, it was immediately apparent to teachers and administrators that the day would produce difficulties. "The biggest problem was that half the students would not go to classes," said Mike Stipac, the school's Vice-Principal. "[They] were just milling around the halls threatening trouble." 54

After a morning fight sent a fifteen year-old student, Shirley Griffin, to the hospital with a hip injury sustained from a fall down a flight of stairs, tensions within the school rose. ${ }^{55}$ Four small fires set in the school's science lab, as well as a garbage can fire in the music department, necessitated the calling of the fire department, which led to the forced evacuation of the school's 1,530 students. ${ }^{56}$ Additionally, according to The Oregonian, small numbers of African-American students reported to have been chanting, “They’ve killed our leader" throughout the school's hallways, referencing the previous day's assassination of King by a white man. ${ }^{57}$

Nathan Proby, a youth worker in the Albina area and an African-American police officer, was prominently and strategically placed within the school halls by administrators in an effort to institute trust in the law enforcement workers patrolling the building. Familiar with many of the students who were actively participating in misbehavior that Friday, Proby spoke frankly: "I know a lot of these kids and told about 60 of them to go home - be gone. Most of these kids are good kids, but there are a few 
bad apples like anyplace else." ${ }^{, 58}$ Don Barrett, a community worker and liaison to Jefferson High School, argued that while there was unrest throughout the early morning, administrators and community members had expected worst. "We anticipated more trouble than this, and we're very pleased that it was only minor." ${ }^{\text {59 }}$ Part of this success, according to Barrett, came as a result of the efforts of civic-minded Jefferson students of both races, who, sensing the potential for a riot, attempted to ratchet down the animosity. According to that Friday's Oregonian, Jefferson High was the only public school in Portland that had been affected by such fraught racial tension.

After the events of the morning, and anticipating the difficulties of trying to hold afternoon classes, school administrators reluctantly dismissed students from school early Friday afternoon. In the aftermath of the dismissal, a large group of students from Jefferson proceeded to loiter around the area near the school, moving as far as NE Killingsworth St. and Union Ave. ${ }^{60}$ As conflict between the roving group of students and neighborhood police officers looked to be escalating, requests were made for additional police units, who arrived in time to find a small segment of people engaged in throwing rocks at police and law enforcement vehicles. By mid-afternoon, and shortly after the window of a police car had been broken by a thrown rock, the groups of students dispersed for good. ${ }^{61}$

On the following day, Saturday, April $6^{\text {th }}$, two days after King's death, Assistant Superintendant of Portland Schools Lawrence E. Winter announced that, as a "tribute to Dr. King and his contribution to the nation," Jefferson High School would be closed the following Monday and Tuesday. ${ }^{62}$ Stating that while Jefferson was the only Portland school that garnered consideration for closure, and that phone calls from parents in other 
districts indicated that they were opposed to cancelling classes, Winter and school board member Howard L. Cherry conceded that students in other Portland high schools could also remain home during those two days provided their parents excused the absence. ${ }^{63}$ In a statement to the press, Winter recommended that all Portlanders use the days off to pay their respects to Dr. King and his causes by participating in memorial services, family discussions, or church programs. ${ }^{64}$

While the suspension of classes at Jefferson was, according to press reports, to honor Dr. King's legacy, many others saw the school's closing as a concession that budding racial tensions had engulfed the school's administration. Ted Yaw, the chairman of the school board, upon hearing of the school closure, asserted that the prime motivation for the closure was "to let racial tensions ease." acknowledging the role race played in the decision, did allude to it an article in The Oregonian. "'No other high school is more than 10 percent Negro,' he explained, 'and all were calm Friday except Grant High School where two trash can fires were reported.",66 Another Portland school board member, R.W. de Weese, confessed to being puzzled by the board's decision to close the school, and said he was unaware of any racial tension that might have played a motivating role in it. ${ }^{67}$

The uncertainties and ambiguities surrounding the decision to close Jefferson ultimately served as a precursor to a statement the following day opening the school back up. Declaring that Jefferson would hold all regular classes on Monday and all morning classes on Tuesday, School Board Chairmen Yaw and Portland Asst. Supt. Winter stated that any reservations and concerns parents might have regarding student safety were unfounded. "Adequate supervision will be provided through the cooperation of parent, 
school and community groups to assure safety of all personnel," the statement noted. ${ }^{68}$ While Yaw and Winter initially refused comment on the impetus behind the administrators' change of mind, Howard L. Cherry, a school board member, stated that a special board meeting had been held a day earlier in response to complaints from many Jefferson area parents and residents that they were being treated differently than others in the city. After listening to the arguments Jefferson area parents made, the Board ultimately decided to overturn the school's two-day closure in favor of a half-day suspension of classes on Tuesday morning in a gesture meant to honor Dr. King. ${ }^{69}$

The atmosphere at Jefferson High School that Monday, contrary to conventional wisdom, proved to be relatively mundane. While the throwing of a Molotov cocktail into the building the night before seemed a possible indication of things to come, the presence of additional on-duty police officers, volunteer parents, and temporary community aides placed throughout the school halls and classrooms led to a docile setting in which most students went through their day quietly. By mid-day, only half of Jefferson High School's 1,700 students had arrived, likely the result of confusion generated by the school board over the weekend. "Apparently, they're kids who just found out we're having classes today after all," remarked Principal William Knouff. ${ }^{70}$

Despite the ordinary nature of the school environment that Monday, concerns over the potential for future violence among students and staff prompted additional action from the Portland School Board. In an executive session following a meeting with Mayor Schrunk, the school board, with the blessing of Chief of Police McNamara, dictated to Superintendant Melvin Barnes that he arrange for additional police protection, community aides, and whatever other necessities would be needed at Jefferson to control 
unrest. "We're going to give the Jefferson administration what it needs to control the situation," stated Board Member John C. Beatty, Jr., "even if we have to sell some property to get the money." At the root of the problems at Jefferson, argued Principal Knouff, were thirty to forty "hard core" boys between sixteen and twenty-one years old. "I can't believe we are going to let 30 or 40 boys disrupt a fine school like Jefferson and the whole city," Knouff stated. "We can't have fear reign among residents out there. We already have a flight of white people to the suburbs from that area. It frightens me." ${ }^{, 71}$ Echoing Knoff's reference to changing racial demographics of the area, Chairmen Ted Yaw went even further, stating that in two to three years, all the Jefferson Students would be black unless steps were taken. ${ }^{72}$

Finding themselves unanimously supported by the board in efforts to control and deter unrest, Knouff and Barnes recommended that North Commercial and North Kerby Avenues, the main streets running by the school, be sealed off during all hours when school was in session. Such an action, claimed the men, would combat efforts by suspended and expelled students, as well as visitors from other schools, who drove and loitered by the school in an effort to undermine authorities. City Attorney Alex Brown, however, quickly dismissed the idea stating that it was extremely difficult to deny use of an entire street to city residents who needed to use it.

While school administrators and board members were united in much of the decision-making at the Monday night meeting, Jefferson High teachers had a separate list of issues for discussion. R.O. Smith, speaking as the social studies supervisor for the district schools, spoke to the board about the disparate treatment of African-Americans in many of the textbooks being used, or being considered for use, in the fifth, seventh, and 
eleventh grade social studies classes. In searching for textbooks for future years, Smith asserted that "One of our major problems now is to separate good material from what is sheer junk." ${ }^{, 73}$ Supt. Barnes, while non-committal in changing district policy, did acknowledge that "most textbooks have said too little about the Negro's place in American history and some have said the wrong things."

Charles Harris, representing the Portland Federation of Teachers and voicing concerns over teacher safety at the school, lobbied the board to provide insurance for the medical costs and salary losses of any teacher who might be physically assaulted at the school, causing them to miss work, as well as insurance covering private property, such as cars, on the off chance they were damaged by students. Following Harris' presentation, however, board member John C. Beatty quickly rejected the proposition, arguing that such actions weren't likely to occur in the future tabling the discussion for a future meeting. ${ }^{75}$

The concerns of teachers such as Smith and Harris served as two of the many examples of problems still facing Portland's black and white residents. As displeasure over the perceived double standards at Jefferson High School continued throughout that school year and into the summer, many African-Americans, perpetually aggrieved by perceptions of themselves as part of a permanent second class, continued to feel thwarted. Much of Portland's predominantly white society saw community violence not as a product of institutionalized racism but rather as a product of changing racial demographics, the emergence of aggressive black militant movements, and the enabling of politicians such as President Johnson and his liberal domestic policies. 
On volatile urban issues such as housing, education, and unemployment, inequalities between the races continued to widen, while any substantive dialogue concerning how to fix such chasms faltered. In June of 1968, however, a detailed analysis of the realities of Portland's racial problem, which had been vaguely alluded to and suggested in the findings of the Kerner Report that March, came barreling to the forefront.

Anticipating the release of the Kerner Report in March, the City Club of Portland, a nonprofit, nonpartisan civic organization formed in 1916 with the goal of researching and debating social and governmental policy in the city, formed a Committee of Racial Justice to "respond in terms of the Portland community to the report." previously written an informational report titled "The Negro in Portland: A Progress Report 1945 - 1957," the City Club's response to the Kerner Report, "Problems of Racial Justice in Portland," served as the Club's first foray back into the topic of race relations in Portland in eleven years. Focusing on eight specific areas, among them employment and economic opportunities, police and law enforcement, education, and housing, the report maintained that one common denominator, "the neglect of citizen involvement," was prevalent in each problem area, and served as an essential factor in characterizing the local government. "It encompasses the failure on the part of local government to establish and maintain lines of effective communication with the citizens it serves," the report stated, "and, most significantly, with the residents of Albina and other depressed areas." 77 This lack of involvement, according to the document, created both misunderstanding and a sense of inferiority among the city's African-Americans, as it related to their interactions with the city. "Actions taken 'for' them are readily translated by them as actions taken 'on' or 'at' or 'against' them," it stated. "Thus, hostilities are 
aggravated, indignities are multiplied and the failure of citizen-government

communication is compounded." 78

The City Club report concluded that, despite population, demographic, and geographic differences between Portland and many other major urban areas, the contents in the Kerner Report could be applied to Portland. In fact, in many respects, the report argued, the relatively small population of the African-Americans in Portland enhanced the significance of Kerner's findings. Most notably, unlike major metropolitan areas in cities such as Los Angeles, Detroit, and Chicago, the comparatively small number of black residents in Portland made it easier for the city's much larger white population to forget about, neglect, and ignore the Albina district and the problems within it. Additionally, the report stated that because of its smaller size, blacks in Portland were likely more permissive of the discrimination they faced to a degree that much larger populations of African Americans were not. Lastly, the City Club argued that while the problems within the Albina community were not qualitatively different than those in other cities, the fact that they were smaller, just by sheer size of the black community, made continued intransigence by white officials and city leaders to identify and correct them, inexcusable. ${ }^{79}$ As E. Kimbark McColl, a member of the study committee that prepared the report stated when it was released, "What this report really states is that the white, moderate, responsible Portland is where the trouble lies." ${ }^{, 80}$

In concluding their assessment of Portland, the report stated that the tensions and unrest present in much larger communities existed in Portland as well. Weaknesses in citizen-government relations were "particularly marked with respect to blighted, depressed, or deprived neighborhoods and minority groups, including, very notably, the 
Albina community. ${ }^{, 81}$ Portland was not, as the black community had known all along, different than its national counterparts. As the report stated, to the extent that the problems of Portland were dissimilar from those of more prominent racial turmoil, "the issue was degree, not of cause and effect, or of urgency." ${ }^{\circledR 2}$ Whether such a thoroughly analyzed and detailed assessment of the racial problems of the city would be taken seriously remained to be seen. What was apparent, however, was that the avoidance, evasion, and benign neglect of the city's racial problems by politicians, press, police, and citizens was no longer a sustainable strategy.

Despite the adoption of the sixty-one page report on June 13, there were still members of the City Club itself opposed to it. Rufus Butler, an Albina resident, director of the Albina Art Center, and the sole African-American on the study committee before resigning from it, not only argued that the club possessed no mandate with which to prepare such a report, but also argued that the document was written too quickly in an effort to produce a result before the summer. The effort by the City Club to produce a report early enough to release and possibly avert summer disorders, argued Butler, ultimately led to a lack of thoroughness in reporting and inaccuracies in the its statistics. "The report was not even conducted as it should have been. The entire research took only two months and yet they have taken years to study sanitation problems." 83

Refusing to sign the report because he thought it too mild, Butler also questioned why, given the racial composition of the City Club, such an organization felt empowered enough to speak on behalf of Portland's African-Americans when there were black intellectuals and leaders in the city who could, with greater accuracy, meticulously present a picture of the African-American community. "The committee members have 
no knowledge of black people," Butler said in an interview with the Oregon AdvanceTimes. "In the report, they stated that they had made an effort to contact the poor, and yet there were no poor or even average citizens listed in the back of the book as having ever been interviewed." ${ }^{\circledR 4}$ Because the report failed to touch upon the central argument of the Kerner Commission, that white racism was at the heart of many African-American problems, Baker felt the black community would likely be indifferent to its findings and find it paternalistic. ${ }^{85}$ "Everything should have been related to white racism, but it was not. They managed to stay in the middle. They didn't talk to black or white extremists. They played it safe." $\$ 6$

Other criticisms of the report by City Club members struck many of the same tones. Dr. William Levin described the report as both prejudicial and destructive, and questioned why the mayor had not been interviewed for the inquiry, given that it indicts the city government's inaction on problems of race. When Levin requested that the report be sent back to the committee for future work and research, his request was ruled out of order. A request for postponement of consideration of the report, also made by Levin, was also voted down. ${ }^{87}$

Responding to the City Club of Portland report that African-American jobs, more than anything else, was integral to solving the problems related to housing, education, and public welfare, Portland's city commissioners disputed the findings, calling it an "indictment" of City Hall ${ }^{88}$ In a press conference called by Stanley Earl, the commissioners described the report as "shallow ... inflammatory ... irresponsible ... inaccurate, misleading, and divisive," and suggested that some of the accusations made against the police bureau were libelous. ${ }^{89}$ Himself a member of the City Club, Earl 
complained that the civic organization failed to interview a single elected official or ranking member of the fire or civil service board, and fiercely resisted the report's insinuation that the fire bureau, which was directly under his jurisdiction, engaged in either discriminatory behavior or indifference toward black applicants. Speaking on behalf of Police Chief McNamara's input, Earl stated that despite greater efforts by the police bureau, the recruitment of African-Americans had largely been unsuccessful because the job had stigmatized by the black community. Furthermore, Earl maintained that African-Americans were not harassed or subjected to slower response times on police calls, and that any issues of police brutality or abuse by an officer should be seen as an indictment of the individual officer, rather than the force at large. ${ }^{90}$

Commissioner William A. Bowes, speaking to the report's conclusions on issues of black employment, stated that issues facing African-Americans would "not be solved by shallow studies, followed by inflammatory and irresponsible statements," while Commissioner Ivancie described the report as "long on the Kerner Report and short on facts about Portland." Ivancie stated that efforts to single out the city as prejudiced in its hiring and employment practices was "grossly unfair," and cited the fifty blacks employed in the parks bureau, as well as the thirty blacks who worked in the public works, as evidence that contradicted the report. ${ }^{91}$

As the City Club Report continued to be read and digested by Portlanders in the aftermath of its release, the conclusions and ultimate meaning of the document underwent intense scrutiny. An Oregon Journal article written on June 17th titled "Generalizations Hit in City Club Report," the last in a series of articles printed that week focusing on racial justice, acknowledged that much of the City Club Report, and particularly sections 
concerning data on public welfare, were general in nature and lacked the specificity to draw the conclusions it did. Nevertheless, the article was quick to condemn those who focused so narrowly on minor inaccuracies that they missed its overarching messages. The fact that so many law enforcement officials, public authorities, and city officials reacted so defensively to criticism of their programs and behavior "is evidence that here, too, the specter of 'white racism' - the insidious, subconscious kind that is the greatest threat - is not recognized by the 'good white folks' who practice it," asserted Oregonian writer Morton Spence. ${ }^{92}$ An Oregon Advance-Times op-ed from June $20^{\text {th }}$ titled "Criticism in City Club Report Found to Be Valid," while also finding fault with some of the report's claims, ultimately acknowledged that much of the conclusions concerning the presence of prejudice in Portland were accurate.

The City Club's report on race in Portland loomed large over much of the summer of 1968. Various efforts by politicians, civic groups, and activist organizations to confront issues of racial prejudice and improve city policy, were viewed, both by the participants and the observers, against the backdrop of the city's purported white racism. Black Summer, an educational program in the Albina district aimed at teaching black history to neighborhood youths in a less structured academic environment, implicitly became seen through a prism of race when the program's director stated that area streets must be cordoned for the project so that participants “don't have to worry about having their brains blown out by pigs. ${ }^{, 93}$ Mayor Schrunk, visiting Chicago for the United States Conference of Mayors, where he was installed as the new president, echoed both reports and used the opportunity to address the comparisons of Chicago and Portland ghettos. "I shall go back to Portland to work even harder to correct some of the problems we have 
there, to make a similar occurrence there impossible," he declared. ${ }^{94}$ Even the Portland police department, attempting to foster a better relationship with Albina youth, hired ten black teenagers who were tasked with creating "a better understanding between the police department and Albina residents." 95

While shifts in policy among Portland's political class enhanced the image of the police department with the public, their efforts to bridge the divide with the black community were ultimately disingenuous. Leaders such as Mayor Schrunk spoke of working with the community to confront the problems facing Albina yet the city's police force continued to increase its surveillance of local civil rights activists, often working to "link him or her to various illegal activities until they found a charge that would stick." "96 While Portland's efforts at monitoring individuals it deemed to be subversive had begun in the mid-1960s, the FBI's expansion of its own counter-intelligence program (COINTELPRO) to a number of states, including Oregon, in March of 1968, provided the local police officers with a legitimacy it previously lacked. Armed with federal backing, local FBI agents began engaging in efforts to disrupt and intimidate the movements, organizations, and individuals they saw as threatening the status quo. ${ }^{97}$

On July 11 and October 7, as part of the Government People - People to the Government program, the Mayor and City Council members held "little city hall" programs aimed at giving citizens an opportunity to ask city leaders about the services the city provides, as well as the functions of the city government. Aimed at eroding the perception of a city government out of touch with their citizens, and particularly their constituents in the Albina district, the events were open to any member of the community. 
Heavily advertised in the newspapers, hyped by word of mouth, and open to all, the dialogue between citizens and their elected leaders proved to be terse, brusque, and, at times, contentious. At the first "little city hall," hosted by Buckman Elementary School in SE Portland, the indifference of the city commissioners, and particularly Commissioner Ivancie, brought displeasure to many in the community. One attendee, feeling disrespected by the demeanor of the commissioners, demanded increased input by citizens. "We could receive better answers. We vote you in," the man argued. "You are dealing with people - not animals. You can't tell us - you ask us." ${ }^{.98}$ At the October meeting, this time at Boise Elementary School in the Albina district, the first time a "little city hall" had been held in the area, emotions again ran high when the conversation turned to police behavior in black neighborhoods. "I have more respect for prostitutes than your officers on the police department," declared R.L. Anderson. "You say you tried ... In all seriousness you know the game. You better start hearing their trouble. You have been warned - told - asked - and baited - the citizen. The black people want a fair shake in Portland." 99 While certain issues raised by Albina residents at the meeting were settled, the meeting ultimately ended in the same manner as many others - a stalemate.

As Albina residents continued to voice their frustrations to city leaders, the police persevered with their efforts to marginalize their own constituents. The Police Community Relations Unit, set up earlier in the year to improve police-community relations, had done little to foster improvement. Despite earlier hopes that the PCR Unit would provide civilian oversight of police activities in Albina, it soon became clear that police officers never wanted, and would never allow, such oversight to occur. "Top 
echelon men want to keep it [the police bureau] twenty-five years behind the times," stated a member of the Metropolitan Human Rights Commission. ${ }^{100}$

New laws to curb prejudice, a renewed commitment to civil rights activism, an honest assessment of the role of racial prejudice, and an open dialogue between city leaders and their constituents had all, to one extent or another, wilted in the face of the status quo. If the aftermath of the 1967 disturbances had brought renewed efforts at improving race relations in the city, a year later a candid appraisal of such labors could only be judged as falling short. Whether blame was to fall on the absence of political will, insufficient economic means, an entrenched and antiquated perspective on race, or the passivity of the demands for racial justice, no one could be certain. But without seismic changes to Portland, any efforts to improve upon the standing relations between the races would be seriously thwarted.

\footnotetext{
${ }^{1}$ William Sanderson, "Bitter, Frank, Articulate Youth of Albina Speaks Up," Oregonian, August 6, 1967, 4M 6F.

${ }^{2}$ Portland City Council, City Ordinance 125110 (Portland, 1967), City of Portland, Stanley Parr Archival and Record Center, City Auditor.

${ }^{3}$ Terry Schrunk, survey responses to Congressional Quarterly Service, August 11, 1967, City of Portland, Schrunk papers, Stanley Parr Archival and Record Center, Portland City Archives, AF/167044, A 2011002.

${ }^{4}$ City of Portland, City Code for the Reporting of Civil Disorders, 1967, City of Portland, Stanley Parr Archival and Record Center, Police-Port of Portland (Archival) - Subject Files (Mayor Terry Schrunk), $\mathrm{B} / 35632$.

${ }^{5}$ Terry Schrunk, response to Boston University student Donna Gables, December 28, 1967, City of Portland, Stanley Parr Archival and Record Center, Riots (Archival) - Subject Files (Mayor Terry Schrunk), AF/167044.

${ }^{6}$ Ibid.

${ }^{7}$ Nellie Mitchell, letter to Terry Schrunk, October 22, 1967, City of Portland, Stanley Parr Archival and Record Center, Riots (Archival) - Subject Files (Mayor Terry Schrunk), AF/167044.

${ }^{8}$ Richard Mason, letter to Terry Schrunk, February 2, 1968, City of Portland, Stanley Parr Archival and Record Center, Riots (Archival) - Subject Files (Mayor Terry Schrunk), AF/167044.

${ }^{9}$ City of Portland, memo suggesting ways to improve non-discriminatory employment practices, 1968, City of Portland, Stanley Parr Archival and Record Center, Police-Port of Portland (Archival) - Subject Files (Mayor Terry Schrunk), B/35632.

${ }^{10}$ Urban League, 1967 Annual Convention: People v. the City: Opportunity and Challenge, 1967.
} 
${ }^{11}$ Oregon Historical Society (Archival) - Albina Vertical File 1 of 3 (Albina in the 60s) - C-CAP pamphlet, 1967.

12 Ibid.

${ }^{13}$ Human Relations Commission of the City of Portland, 1967 Annual Report, City of Portland, Stanley Parr Archival and Record Center, Human Relations Commission (Archival) - Subject Files (Mayor Terry Schrunk), B/35605.

14 Ibid.

15 Ibid.

${ }^{16}$ Colden Brown, Jr., "Rapping About Albina," Vanguard, September 27, 1967, 10.

${ }^{17}$ Sanderson, "Bitter, Frank, Articulate Youth of Albina Speaks Up,", 4M 6F.

${ }^{18}$ Steven Reed Johnson, "The Evolution of Civic Activism in the Albina Neighborhood," http://stevenreedjohnson.com/stevenreedjohnson/CivicPdxAlbina_files/Albina\%20Neighborhood.pdf, 20. 19 John Painter Jr., "Study Shows Portland Could Explode," Oregonian, January 28, 1968, 2 M 68.

${ }^{20}$ Human Relations Commission of the City of Portland, A Description of Inter-Group Relations Problems in Portland and Challenges for 1968 (1968), 1, City of Portland, Stanley Parr Archival and Record Center, Human Relations Commission (Archival) - Subject Files (Mayor Terry Schrunk), B/35605.

${ }^{21}$ Ibid.

${ }^{22}$ Editorial, "Problem Exists Here, Too," Oregon Advance-Times, March 7, 1968, 3.

${ }^{23}$ A Description of Inter-Group Relations Problems, 2.

24 Ibid.

${ }^{25}$ Ibid., 9.

${ }^{26}$ Ibid.

27 “Chance Open for Negroes to Get Fire or Police Jobs," Oregon Advance-Times, February 1, $1968,3$.

${ }^{28}$ Wayne Thompson, "Race Report Greeted By Enthusiasm, Hope, Plus Skepticism on Pertinence to Portland," Oregonian, March 3, 1968, 4M 29.

29 Ibid.

${ }^{30}$ Ibid.

${ }^{31}$ Ibid.

${ }^{32}$ Ibid

${ }^{33}$ Ibid

34 Ibid

35 "Problem Exists Here, Too," 3.

36 "Riots Hit 40 Cities; 20 Dead," Oregon Journal, April 6, 1968, 1.

37 “King Death Termed 'Ironic' by McCall," Oregon Journal, April 5, 1968 , 5M 4J.

${ }^{38}$ Jack Berry, "Assassination Saddens Portland Leaders; Fuel For Advocates of Violence Feared," Oregonian, April 5, 1968, 4M 14.

${ }^{39}$ Ibid.

40 Ibid.

41 Ibid.

42 Ibid.

43 Ibid.

${ }^{44}$ Ibid.

45 “Clerics Tell Mayor to Aid Negroes Here,” Oregon Journal, April 6, 1968, 1.

46 Ibid.

47 Ibid.

${ }^{48}$ Nelson Pickett, “King’s Death Considered Blow to Nonviolent Movement," Oregon Journal, April 5, 1968, 5M 4J.

${ }^{49}$ Morton Spence, "Militants Here Vow to Advance Cause," Oregon Journal, April 5, 1968, 5 M J3.

${ }^{50}$ Ibid.

51 “Jeff Calls 2-Day Halt,” Oregonian, April 7, 1968, 1.

52 Rob Lawson, “Jeff Problems," Oregon Advance-Times, February 29, 1968, 9. 
${ }^{53}$ Ibid.

54 "Jeff High Shut Down By Unrest," Oregonian, April 7, 1968, 1.

55 "Jefferson Classes Out Early," Oregon Journal, April 6, 1968, 5M J3.

56 "Fire Clears School," Oregon Journal, April 5, 1968, 5M J3.

57 "Jeff High Shut Down By Unrest," 1.

${ }^{58}$ Ibid.

${ }^{59} \mathrm{Ibid}$.

60 "Jefferson Classes Out Early," 5M J3.

${ }^{61}$ Ibid.

62 "Jeff Calls Two Day Halt," 1.

63 "Jefferson to Close as King Tribute," Oregonian, April 7, 1968, 3M 19.

${ }^{64}$ Ibid.

65 "Jeff Calls 2 Day Halt," 1.

66 "Jefferson to Close as King Tribute," 3M 19.

${ }^{67}$ Ibid.

68 "All Portland Schools to Open On Monday," Oregonian, April 8, 1968, 1.

${ }^{69}$ Ibid.

70 “All Schools Here Set Late Start Tuesday," Oregon Journal, April 8, 1968, 7.

71 "Jefferson Due Extra Policemen," Oregon Journal, April 8, 1968, 4M J3.

${ }^{72}$ Ibid.

73 "Race Woe Occupies Board," Oregon Journal, April 9, 1968, 1M.

${ }^{74}$ Ibid.

${ }^{75}$ Ibid.

${ }^{76}$ City Club of Portland, "Problems of Racial Justice in Portland," Richard W. Nahstoll, Chair, 49 (1968), 5 .

${ }^{77}$ Ibid., 7.

${ }^{78}$ Ibid.

${ }^{79}$ Ibid., 8.

80 "Racial Justice Report Adopted By City Club," Oregon Journal, June 15, 1968, 5 M J3.

81 "Problems of Racial Justice in Portland," 8.

${ }^{82}$ Ibid., 9.

83 "Butler Airs Views on City Club Report," Oregon Advance-Times, June 20, 1968, 1.

${ }^{84}$ Ibid.

85 "Racial Justice report Adopted by City Club," $5 \mathrm{M} \mathrm{J} 3$.

86 "Butler Aires Views on City Club Report," 1.

${ }^{87}$ Ibid.

${ }^{88}$ Jack Ostergren, "City Commissioners Dispute Findings of City Club Report," Oregon Journal, June 13, $1968,5 \mathrm{M} \mathrm{J} 3$.

${ }^{89}$ Ibid.

${ }^{90}$ Ibid.

${ }^{91}$ Ibid.

${ }^{92}$ Morton Spence, "Generalizations Hit in City Club Report," Oregon Journal, June 17, 1968, 4J 4M.

93 “"Black Summer' Progressing," Oregon Advance-Times, June 13, 1968, 11.

${ }^{94}$ Ken Jumper, "Chicago Riot Issues Studied by Schrunk," Oregon Journal, June 15, 1968, 3M 2J.

95 "Police Hire Ten Black Teenagers," Oregon Advance-Times, August 8, 1968, 1.

${ }^{96}$ Karen J. Gibson and Leanne C. Serbulo, "Black and Blue: Police-Community Relations in Portland's Albina District, 1964-1985," Oregon Historical Quarterly 114:1 (Spring 2013), 14.

${ }^{97}$ Ibid., 13-14; Ward Churchill and Jim VanDerWall, The COINTELPRO Papers: Documents from the FBI's Secret Wars Against Domestic Dissent (Boston: South End Press, 1990), 108. 
${ }^{98}$ Portland City Commissioners, Minutes of Little City Hall Meeting at Buckman School, Meeting of 11 July 1968, City of Portland, Stanley Parr Archival and Record Center, Human Relations Commission (Archival) - Subject Files (Mayor Terry Schrunk), B/35605.

${ }^{99}$ Portland City Commissioners, Minutes of Little Town Hall Meeting at Buckman School, Meeting of 7 October 1968, City of Portland, Stanley Parr Archival and Record Center, Human Relations Commission (Archival) - Subject Files (Mayor Terry Schrunk), B/35605.

${ }^{100}$ Sanderson, "Bitter, Frank, Articulate Youth of Albina Speaks Up,", 4M 6F; Robert Olmos, "Community Relations Unit Fights Bombing," Oregonian, May 9, 1971, 98. 


\section{Chapter 4: Blow-up (1969)}

As Portland residents and officials continued their efforts to improve city race relations, an increasingly contentious national racial atmosphere brought on by the rise of Black Nationalist groups such as the Black Panther Party for Self Defense, a self-defined revolutionary organization that attempted to curb police brutality towards AfricanAmericans, began to indirectly affect local events.

In May of 1968, a group of forty men and ten women, led by University of Washington student Aaron Dixon, officially established a chapter of the Black Panther Party (BPP) in Seattle. Portland's black-owned Oregon-Advance Times was the lone newspaper in the City of Roses to cover the event. "The Black Panther Party for SelfDefense is moving closer to Portland," the newspaper proclaimed. Citing a long history of racial segregation, discrimination, and neglect, the Advance Times pointedly noted the similarities between the racial climates of the two main cities of the Pacific Northwest. ${ }^{1}$

While Portland had succumbed to instances of racial turmoil such as the Irving Park disturbances of 1967, the city had successfully avoided the major racial altercations and clashes that had marred many American cities. Nevertheless, Portland police officers continued to confront the more radical elements of the African-American community. In July 1968, the police were notified of a plan by unnamed individuals living in the Albina district to instigate a racial uprising. Alerted to the scheme by an informant, officers understood that the uprising was to take place during the last weekend of July in retaliation for what the perpetrators believed had been the physical assault of a black girl 
by a white cop. ${ }^{2}$ While the racial uprising never took place, the clandestine manner in which such large-scale plans seemed to have been formulated and disseminated throughout the community elucidated the difficulties faced by city police in curbing racial discord. Other efforts towards violence made by more militant members of the black community, such as the intimidation and threatening of business owners and the targeting of businesses for firebombing, served as further proof of the schism not only amongst Albina's old guard, represented by the predominantly black business owners of the district, and their angrier and more militant younger counterparts, but also in the acceptable tactics and strategies of the civil rights movement nationwide.

As racial tensions within Albina continued to fester, the long-term effect of the antagonisms between the area's older blacks, younger blacks, and city police wrought previously unforeseen problems. In the aftermath of the disturbances of 1967, businesses along Albina's busiest thoroughfare, Union Avenue, fearful of firebombing attempts and future vandalism, began to protect their businesses by placing wood and steel boards along windows facing the street. Such "anti-riot" décor, while purportedly keeping the workers and patrons of such businesses safe, also created the appearance of an unwelcoming neighborhood, further depressing the area's real estate and discouraging new investment. Worsening the problem, many businesses within the area, frustrated by the cost and symbolism of the outfitting repairs needed to stay there, saw opportunities to relocate to less volatile parts of the city, where damage to their business was not likely to occur. Insurance companies, forced to pay claims on the $\$ 50,000$ worth of damage that occurred in Portland during the 1967 disturbances, began refusing to renew policies in the 
area, discouraging affected businesses to remain. ${ }^{3}$ Marvin McKinney, Jr., a local insurance agent, stated that "an unwritten law" existed in the insurance industry "not to write policies" for segments of Albina following the Irving Park disturbances. ${ }^{4}$ Once thought of as having the potential to be one of the most progressive and innovative neighborhoods of the city, Albina in 1969 remained stunted by many of the same problems that had plagued it over the earlier years of the decade.

While black unemployment, substandard housing, and de facto segregation in the local schools tended to dominate the grievances of many of Albina's residents, it was the contentious and volatile relationship between the community and the police that ultimately led to a second violent collision in Albina less than two years after the first. Despite efforts by city officials and local civil rights advocates to improve policecommunity relations, tensions in Northeast Portland in the late 1960s between police and African-Americans were perilous. Jimmy "Bang-Bang” Walker, a civil rights advocate, African-American journalist, and editor of The Clarion-Defender, one of two black newspapers in Portland at the time, routinely used his newspaper to expose purported police brutality. In an October 1968 editorial titled "Ghetto Tactics," Walker recounted an episode in which Officer Clark Paul, a white male police officer, had both struck an elderly black woman during a traffic stop, while simultaneously threatening to arrest Walker for attempting to intervene. "It was reminiscent of the way George Wallace plans to handle police matters involving black people," observed Walker. ${ }^{5}$

Other accounts of police harassment, detailed in the City Club of Portland's Report on Law Enforcement, 1968, highlighted the manner in which officers who 
patrolled the area treated Albina residents. The police were consistently slow to respond to the neighborhood when requested by residents threatened with violence, and would often refer to black males as "'boy' and other derogatory names" when they did. Moreover, officers would routinely stop black motorists throughout the neighborhood without cause or suspicion, often targeting interracial couples for questioning and frequently engaging in verbal abuse. "My wife was stopped by the police on night around 11 p.m." recounted one black interviewee in the Report. "He came to the car and said, 'Where are you going, Bitch?'” An attorney interviewed for the City Club Report stated that he felt it was police policy to engage in the practice of targeting and stopping black residents on the basis of their race alone. ${ }^{6}$

Kent Ford and Percy Hampton, Portland black activists who would co-found the city's chapter of the Black Panther Party in the summer of 1969, saw the police as unabashedly detrimental to the African-American community. In July 1968, while walking to the grocery store, Hampton was stopped by a police car. "“Boy, where you going?"”, Hampton recalled the officer as demanding. “'My name is not boy,"” Hampton responded, before being attacked for insolence and placed in jail for ninety days under an assault charge. ${ }^{7}$ Such behavior by the police, according to Ford, fed the resentment that allowed the Black Panthers to flourish. "I can count on one hand the people we actually recruited," stated Ford. "In those days, the police did most of our outreach." antagonistic relationship between the police and local residents served as the backdrop for the conflict that took place in Northeast Portland in mid-June of 1969. 
Late on the night of Friday, June 13, after receiving numerous complaints from area residents concerning the throwing of rocks and bottles from rooftops and street corners, Portland police officers arrived at the corner of N.E. Union Avenue and Shaver Street, where they encountered a large congregation of black youths. Lidio's Drive-In, a fast food Italian restaurant which sat at the corner, was one of the businesses in the Albina district that chose not to leave the neighborhood following the turmoil of 1967. Freely catering to both black and white patrons, the restaurant often became a gathering point for Albina's youth population, given its central location within the neighborhood, as well as its general tolerance for a younger demographic of customers. Officers Clyde Harmon and B.R. Robinson, deeming a fifteen-year old in violation of city curfew laws on the night in question, attempted to arrest the youth, an action that precipitated a clash between nearly 150 young people and the two officers. ${ }^{9}$ As they sought to place the young man into a police car, one of the officers was knocked down and beaten, sustaining a cracked rib in the process, while bystanders, according to news reports, taunted the officers, physically beat on the police car, and slashed one of the tires in an effort to prevent it from driving away, which it eventually did. ${ }^{10}$

Five additional units were immediately dispatched to the scene while thirteen separate units moved into the surrounding area. Richard Southern, a West Linn High School graduate who had been a police officer for only three hours, was one of the first to respond. Arriving to find a crowd of nearly sixty young blacks, Southern and the other officers immediately picked up on the root of the gathering's displeasure. "Someone in 
the crowd yelled, 'Get Whitey!'” Southern told the Oregonian four days after the event. "The crowd action was directed; it was not just something that grew."11

Once police descended upon the area, crowds of young people began throwing rocks at the windows of local businesses in a repeat of the vandalism that had taken place two years earlier. Driving along Union Avenue, fifty-two-year old Broadway cab driver Thomas J. Kelly was dragged from his car and assaulted by nearly thirty attackers, as his vehicle, still in gear, rolled through the front plate-glass window of Weimer's Furniture store. Two other motorists that evening, Richard Dowty and passenger Gale Starr, were also forcibly removed from their car by a small gang of teenagers, but suffered no serious injuries, despite reports they had been assaulted and treated at St. Vincent Hospital. ${ }^{12}$

An Oregon Journal account of the event stated that shortly after the disturbances began, the police engaged in "swift, club-swinging battles with the gangs." Larry Brown, the Lieutenant of Portland's North Precinct, was himself struck in the jaw during the conflict, partially the result of police efforts to minimize violence. "No policeman pulled a gun and no shots were fired by us," Brown said in praise of his men's restraint. Brown also acknowledged the efforts of the large number of local residents who attempted to force angry youths off the streets and into their homes. By daylight, as the roving groups of attackers finally broken up and dispersed, the clash came to a halt. Nearly three and a half hours after the violence first erupted, the Albina streets were clear, leaving a final tally of twelve arrested, twelve injured, and a damage toll to be determined. ${ }^{13}$ 
Despite the brevity of Friday night's disturbance, the détente between law enforcement and the community was short-lived, with scattered and destructive violence that Saturday night as well. Having already arrested nearly forty youths late Saturday night on charges such as resisting arrest, disorderly conduct, and loitering, the police found themselves encountering additional problems Sunday night. On the evening of June $15^{\text {th }}$, police officials, sensing the brewing of possible trouble, moved to close down the Rose Festival Center in Holladay Park, where a large group of teenagers and adults had gathered. Following the closure of the park around 10:30 p.m., the large group relocated nearly two miles away to Lidio's Drive-In, which had served as the site of the previous day's police-civilian clash. ${ }^{14}$ In the ensuing hour, characterized by one police officer as an atmosphere of "total unrest," disorder once again broke out in the area surrounding N.E. Union Avenue and Shaver Street. as the police ordered the gathering to dissolve. $^{15}$

As had occurred the night before, small groups of teenagers, moving first towards Garfield Street and then to Failing, participated in the breaking of nearly sixty windows of nearby businesses, including the Piedmont Pharmacy, Rose City Pharmacy, and Grenfell's Food Market, while police officers were stationed nearby with shotguns to prevent looting. ${ }^{16}$ In contrast to the previous night, however, homes, schools, and businesses, including a flower shop and the Albina legal aid office, were victimized by firebombs or set fires. ${ }^{17}$ Kennedy Elementary School, located near the corner of N.E. $33^{\text {rd }}$ and Killingsworth, suffered $\$ 1,000$ worth of fire damage, while a Molotov cocktail thrown through the a window of the Albina legal aid office led to $\$ 3,500$ worth of 
damage. ${ }^{18}$ Eventually, police were forced to erect a barricade that stretched across Mason and Garfield Streets to prohibit civilian access to fire-starting materials in the fuel yards nearby. ${ }^{19}$

Having established a field headquarters at a nearby McDonald's shortly after midnight, the nearly fifty police officers, including all off-duty personnel present, began making arrests in the Albina district of any individual who refused to disperse upon orders to do so. Despite providing resistance earlier in the evening in the form of kicks, punches, and thrown bottles, those remaining in the area generally obeyed orders. By 1:00 a.m., however, sixteen people had been arrested, including ten juveniles, on charges ranging from loitering to assault with a deadly weapon. By 2:00 a.m, nevertheless despite minor reports of newly broken windows, the second night of major conflict in Albina had concluded. ${ }^{20}$

Nearly six hours after the altercation between police and civilians had ended that Monday morning, a racially diverse group of nearly fifty people had arrived at the downtown police headquarters to protest the jailing of nearly thirty individuals from the previous night's disturbances. Protesting peacefully in both the lobby and the corridor outside, the group sharply condemned the police's handling of the events of the previous two nights. Jimmy (Bang-Bang) Walker of the Northwest Clarion-Defender, an eyewitness during the first night of the altercation, blamed use of excessive force by the police as the reason for the violence. "The police got rougher than they should have and this is when everything got out of hand," he stated. Walker, among others, also disputed the police report of the incident, claiming that officers used unnecessary force as soon as 
they arrived at the scene. "The police need some training," urged Walker. "You need policemen who won't lose their cool when somebody calls him a pig bastard.",21

Speaking to the Oregon Journal, Walker insisted that a large part of the problem centered around the manner in which the police monitored the community, arguing that if officers walked the beat daily, as opposed to riding in their patrol cars, their relationship with constituents would be much improved. Kent Ford, a local black activist already well known to Portland police officers given his role in previous altercations, and one of the twelve arrested during the first night of conflict, criticized the police handling of both the disturbance at Lidio's Drive-In, as well as their general behavior in the community. "People [Albina residents] are going to keep retaliating until the pigs stay out of our community," Ford asserted. "The pigs [police] have no right in the black community." Ford told the Oregonian that the intentionally falsified police reports of the disturbances were the "hogwash of fascist pigs." 22

As African-American activists such as Jimmy Walker and Kent Ford spoke out against police behavior, other black leaders joined in with even more sinister explanations of official conduct. Citing the arrest of five local self-identified black militants, including Kent Ford, Leon Johnson, a former city police officer, argued that the orders were designed to crack down on the most radical activists. Johnson referenced a recent directive by U.S. Attorney General John N. Mitchell targeting African-American radicals and stated that he believed the weekend's incidents to have been staged to achieve similar results. Like Walker and Ford, Johnson questioned the validity of police accounts, arguing that many newsmen only received one side of the story. "I was a 
policeman and I know what goes into those reports," Johnson stated. "Anything an officer wants to write. If you foul up, you aren't going to say so in your report, are you?"23 Even a black member of Governor Tom McCall's staff, speaking on a condition of anonymity, accused the Portland police of provoking the weekend's violence to instigate arrests. $^{24}$

The narrative of a covert police operation aiming to trap and ensnare Portland's local black militants received further exposure in a series of articles published in the local weekly underground newspaper, The Willamette Bridge. Radical in its ideology and content, the Bridge was published between 1968 and 1971 by a group that included members of both Reed College's Students for a Democratic Society (SDS), as well as its offshoot, the Portland Revolutionary Youth Movement. ${ }^{25}$ In their July 3rd edition, under the headline "Black Community Attacked," the newspaper insinuated that police harassment of the black community had resulted from African-American dissatisfaction with the Rose Festival and 'it's 'lily white and good for business' orientation that depicted prosperity unlike any experienced in the black community." The article asserted that the police had sought to proactively discourage local black militants from creating a disturbance that might disparage the Festival and harm participating businesses. By provoking a confrontation, the Bridge insisted, the police were able to intimidate the black community into a more docile role during the Festival, while also having a reason to assail the more active and militant African-American members of the Albina district. ${ }^{26}$

While the Willamette Bridge articles spoke to the potential motivations of the Portland police, they also highlighted key discrepancies in the actual facts of the story. 
Contrary to newspaper reports in the Oregonian and Oregon Journal, or formal police reports of the incidents, the Bridge claimed that on Saturday and Sunday, the nights following the initial conflict on Friday, drunken police officers without name badges and with their car license plates covered, drove around the Albina district beating up black teenagers. ${ }^{27}$ In an interview with the Bridge, a source present at the altercations spoke bluntly. "You got people riding around in their cars they call themselves "police," the man said. "They say they want to kill a nigger. And on several occasions, they've pulled a gun on these niggers. ${ }^{28}$ Citing the arrests of twenty-one activists in New York City and seven more in Oakland, the respondent asserted that the police narrative of a disruptive black population in Portland simply didn't match the trend. "They're starting at the real militant - the Panthers and different organizations, and if they can get them, they can bust down and the get then rest of them right down the ranks," he declared. "They don't have to get the Negroes and the house niggers to go, 'cause they're going to go willingly."29

First-hand accounts by George Davis, the black night manager at Lidio's DriveIn, bolstered the narratives presented by Walker, Ford, and, to a far lesser extent, the claims made in the Willamette Bridge. Interviewed in the Oregonian on Tuesday, June $17^{\text {th }}$, Davis stated that the major conflict on Friday arose when police officers, wearing black leather jackets with their nameplates and badges removed, used their clubs to subdue two black girls they were attempting to arrest. Meeting fierce resistance from a large group present at the scene, tensions were ratcheted up late Saturday night when police began swinging their clubs. ${ }^{30}$ According to the Oregonian account, Davis saw one 
police officer "put his club around a girl's neck and force her into the squad car," while two other officers, in separate incidents, struck two younger males in the head and stomach. According to Davis, such force left one youngster with a broken jaw, another with a broken collarbone, and a third with a broken nose. "After that the kids broke loose on them and started throwing rocks and smashing windows," stated Davis. ${ }^{31}$

Additional witness accounts of police violence, previously relegated exclusively to the city's alternative or black newspapers, began to appear in the Oregonian and the Oregon Journal as well. An Oregonian article titled "Albina Dwellers Charge Police With Beatings, Harassment," revealed that a mother and child had been dragged from their home in the middle of the night after having their door broken down by police. The newspaper also reported the allegations of a young African-American male who claimed he was assaulted with nightsticks before having the cash in his wallet stolen. Dozens of young black males, in addition, reported being harassed and assaulted, suggesting at a minimum that the narratives of the police and some in the African-American community were vastly at odds. "We're going to try to find why so many Albina youngsters have been arrested and beat up," stated Nathan Proby, director of Albina's teen center. "We want to know who is to blame, the kids or the police." ${ }^{32}$

Despite assertions from outspoken elements of the African-American community, police explanations regarding the problems in Albina remained steadfast. Arguing that the problems were the result of rebellious youths who refused to obey police orders, Captain William Taylor, the commander of the Police Bureau, stated that the escalation was predominantly the result of the attack on the first two police officers who arrived on 
the scene on the night of June 13th. "We were forced to call in more men to assist them," argued Taylor. "Our men were met by defiance and resistance - bottles, bricks, fists, and feet. And that was what set it off., ${ }^{33}$ Furthermore, Taylor stated, it was the black militants, rather than the vast multitude of people in the area, who were to be blamed for the troubles. Citing continual efforts by these groups to attack white officers attempting to make arrests in Albina, as well as a purported effort to shut down the Rose Festival, Taylor laid the responsibility for the antagonism and acrimony between the two groups at the feet of the community's militant African-Americans.

The sentiments expressed in the underground Willamette Bridge represented the fundamental antagonism between the city's police force and more radical members of the community. While the younger and more militant members of the black population in the Albina disturbances of 1967 had been predominantly marginalized by more moderate elements, the more recent disturbances seemed to garner more support. Touched off by local accusations of police brutality, a charge that also served as a catalyzing force for militant activists nationwide, as opposed to the perceptions of youthful indiscretion, vandalism, and outsider agitation that generally characterized the disturbances two years earlier, the conflict between police and civilians within the Albina area, while neutralized, was certainly not resolved by the afternoon of June 16 th.

As that Monday's temperature reached 94 degrees, setting a new high for the year to that point, a comparative calm seemed to have settled over the Albina neighborhood. Yet as First Lady Pat Nixon, along with her daughter, Julie, toured four separate areas of Portland, including the Albina Art Center, as part of a nationwide tour highlighting urban 
volunteer projects, local police once again geared up for another night of potential conflict. ${ }^{34}$ Earlier in the day, as a result of the previous weekend's altercations, Don Duehart, a local member of the Black Panther party, and R.L. Anderson, a member of the Albina Citizens Council, announced that black militants would be patrolling the Albina area in marked cars to prevent additional acts of police violence. Calling Mayor Terry Schrunk and Police Chief Donald McNamara "mental incompetents" and demanding their removal, Anderson stated that much as the police were armed during their patrol, so would their neighborhood guard. ${ }^{35}$

Cognizant of heightened tensions, the police showed early signs of strength that night with patrols around Lidio's Drive-In. ${ }^{36}$ Despite reports pointing to a potential turnout of a large group of supporters of those arrested and detained the previous night, however, Monday night and Tuesday morning produced only a few arrests. One detention involved Jimmy Walker, the editor-publisher of the Northwest Clarion Defender. Arrested for disorderly conduct and resisting arrest after refusing, on the grounds that he was a member of the press, the request of a police officer to move to a different location to take pictures of the police clearing a nearby street, Walker claimed to have received injuries during his apprehension that prohibited him from appearing at an early Tuesday morning hearing at the Municipal Courthouse. "When they arrested me, I didn't resist because I felt I was within my rights," Walker stated from his hospital bed. "As they pushed me into a police car, one officer kept jabbing me with his nightstick ... jabbing hard." The arresting officer, while acknowledging Walker's media credentials, indicated that the arrest occurred not as a result of Walker's refusal to move, but rather as a result 
of the profanity Walker directed towards him after his request. "There's some fault on both sides," Walker said. "But it's the responsibility of the police to avert violence." 37

As Albina continued to experience disruptions between the police and community, Portland Mayor Terry Schrunk delivered a presidential report to the U.S. Conference of Mayors 2,500 miles away in Pittsburgh. Schrunk called upon Congress to cede greater authority to local elected officials to find solutions to the urban crises many cities faced. Arguing in opposition to a federal bureaucratic system that slowed down real solutions, the mayor spoke candidly about Oregon's urban problems. "I must say some states, including my own, have opened their eyes to recognizing the urgency of city needs," Schrunk asserted. ${ }^{38}$ As his own city continued to battle the racial turmoil that had plagued the community for two of the past three summers, Schrunk urged national and state legislators to move quickly on block grants and other forms of investment that might address the critical problems of urban areas. Most notable, however, he called for an increase in federal spending to oppose urban crime while urging city leaders to be prepared to "move effectively against problems of disorder and so-called civil disobedience."39

While Schrunk urged city leaders across the nation to be prepared for the "problems of disorder" that often arose in urban areas, the mayor's own absence from Portland during the disturbances left him attempting to provide leadership from the opposite side of the country. Speaking by phone to the Oregonian on Tuesday the 17th, less than twenty-four hours after repeating his message to the Conference of Governors, Schrunk exuded confidence in his own city's handling of its disturbances. Stating that he 
had been in contact with the acting Chief of Police throughout the events, the mayor claimed that while the policy of city police was to not use any more force than was needed when making arrests, he did not expect his officers to back down or retreat when threatened. Schrunk responded to questions regarding charges leveled that police officers had entered homes illegally in an effort to catch suspects by maintaining that while he did not have all of the facts of the case, it was legal for an officer to enter a home when in pursuit of an individual seeking to avoid arrest. Stating that he would make decisions regarding the possible necessity of a city curfew and the closure of specific businesses that served as problem areas upon his return, Schrunk reiterated his confidence in the police force. "I will stack our police force against any in the nation - in training, policy, and administration," he declared. ${ }^{40}$

As Mayor Schrunk defended the behavior of Portland's police department across the country in Pittsburgh, Police Chief Donald McNamara, who had just returned from a law enforcement meeting in Virginia himself, began his own vigorous defense of the bureau. Addressing the allegations of Mrs. Gwen Branch, who had earlier in the week accused two police officers of breaking down her door and entering her home without a warrant, McNamara reiterated Schrunk's contention that officers in pursuit of a suspect who entered a home did not need to produce a search warrant. McNamara also disputed claims that Mrs. Branch's twelve year old son Stanford Grant had been dragged outside the home and arrested. According to the Chief, police records indicated that Grant had been arrested inside the home along with his brother Norman on charges of interfering with a police officer. "The Portland community does not benefit when rumors are spread 
and tempers are inflamed by an incomplete telling of the facts," warned McNamara. "It is immaterial that allegations are eventually proved false ... The damage is done at the moment of telling."

As Schrunk, McNamara, and Patrick Carr, who had served as Acting Chief of Police during McNamara's absence, mounted a vigorous defense of both their officers and their conduct during the turmoil of the three nights in Albina, additional accounts began to surface. An Oregonian article titled "Police Point out Innocent Victims of Beatings by Youth Gangs Also Deserve Protection” referred to the hypocrisy of black militants who, while claiming police brutality on one hand, failed to recognize the violence of their own behavior directed at innocent members of the community. Citing instances such as the beating of a man who was eventually left in a nearby gutter; the dragging of a cab driver from his own vehicle; and a woman who was stripped naked to the waist and verbally insulted by attackers, the feature highlighted the violent nature of many of the groups who, in resisting the police, often found themselves assailing others. Carr insisted that there had not been enough outrage in the community and media towards the agitators. "We know that whenever you get a bunch of kids together with nothing to do, trouble is going to develop," Carr lamented. "The victims of violence we've had in recent days prove that. What we're trying to do is to protect people in the area - keep them from becoming victims." 42

Richard Dowty, the thirty-two year old man mentioned in the article who had been assaulted and left in the gutter by his attackers, stated that he had been dragged from his car by nearly twenty black youths before he was hit in the head with a soda bottle and 
then kicked in the head, rendering him unconscious. Reading news coverage of the incident days later, Dowty was outraged by the portrayal of the police as aggressors and his attackers as the victims. "I read that article about police brutality in the newspaper and it made me mad," Dowty told an Oregonian reporter. "If anything, I feel the police have been too soft on those kids. They should be stricter. Those kids deserve everything they got coming to them.."43

Dale Kenney, another assault victim featured in the article, viewed his attack differently from many others in the white community. Assaulted from behind by six teenagers as he walked home from work, Kenney failed to subscribe racial malice to the motivation of the perpetrators, stating that such violence was merely endemic of contemporary youth culture at that time. "Something like that can happen anywhere, not just in Albina," Kenney was quoted as saying. "It happened to me once before in Tigard. That time the kids involved were white." ${ }^{44}$ Kenney stated that until people woke up to the problem of community violence in general, such discord would continue to be a part of society.

Despite the upheaval of Albina over the previous few days, much of Tuesday had presented a relative calm. Earlier in the day, at the behest of city law enforcement officials, North Precinct Commander Captain William Taylor met with a group of black Albina men and agreed to keep all Portland police officers out of the most troubled areas of the district for forty-eight hours. Making the deal with the explicit agreement that, in return, the men would use their influence to keep the area trouble-free, Taylor and 
McNamara saw the concession as a way to begin repairing the relationship between police and civilians.

Despite the agreement, and an uneventful afternoon and early evening, the arrival of nighttime once again brought trouble. Far from remaining untouched, Albina businesses suffered a significant amount of destruction when twelve separate fires destroyed five buildings in the area. While some in the community had begun to speculate as to the motivation of these acts of arson, the police did not. Over the course of the five days in which arrests were made throughout the area, over twenty youths were arrested on charges of arson, or similar conspiracy charges. While a local arrest also occurred that night for a "serious assault of a white person," that, in fact, turned out to be a Portland firefighter, there were no large-scale arrests or major breakouts of violence like those that had occurred over the previous evenings. In keeping their agreement, moreover, not only did Portland police officers only enter the area to assist with the extinguishing of the fires, but, more impressively, recorded a night of patrol without the use of any firearms. ${ }^{45}$

In spite of this, Portland city authorities remained concerned by the outward defiance of militant blacks towards community advocates for peace and non-violence. Having met with representatives from the multiracial Urban Coalition on Wednesday, less than twenty-four hours after their initial agreement, McNamara could sense the group's frustrations. Ed Mitchell, a member of the group and the coordinator of community services for the Model School Program, continued to lobby for additional time. "We didn't have enough time to get to everybody about the moratorium," Mitchell 
conceded, before implying that a second effort would prove more fruitful. Pointing to the combined efforts by both the police force and the black community on Tuesday night, Mitchell attempted to persuade McNamara and Taylor to hold off on the increase in police officers they were planning for that evening. Fire Chief James Riopelle, in substantiating Mitchell's claims, spoke of a "substantial amount of help" given to his men by African-American adults in the community who kept spectators behind fire lines and prohibited trouble makers from causing additional conflict. ${ }^{46}$

While McNamara listened to the arguments of Mitchell sympathetically, he did not back off his initial plans for an increase in officer levels. Overruling the wishes of Fire Commissioner Stanley Earl, who, frustrated by the harassment of his firefighters, the dangers they faced the previous nights, and their own exhaustion after two full nights of work, advocated for a curfew in Albina, McNamara chose to triple the number of officers who would be present in the vicinity on Wednesday night. Arguing that the incremental reduction in the number of officers in the neighborhood over the previous three nights had not been successful, McNamara stated that the additional reserve officers brought into the district would "meet sternness with sternness." While disappointed with McNamara's decision not to implement a curfew, Fire Commissioner Earl remained gratified by the decision to triple the police presence. "It is my honest belief that 99 percent of the black citizens want law enforcement, and they are entitled to protection," Earl asserted. "The time has come to enforce the laws equally. The City of Portland is not open to negotiation with a bunch of hoods.."47 
Mayor Schrunk also echoed the sentiments expressed by Fire Commissioner Earl upon his return, when he reinforced the city government's mantra that violence of any kind in Portland must be stopped. Believing the disturbances to be the product of a small minority of actors, both black and white, Schrunk emphasized that it was likely that "90 $\%$ of the residents of Albina" wanted no part of the activities occurring in the area. At the same time, the mayor voiced his support for Tuesday night's withdrawal of police officers from Albina, stating that the plan was worthwhile, despite its perceived failure, because it fostered ownership of the community by its inhabitants. "You've got to give citizens of the area an opportunity to take responsibility and become involved in solving problems," Schrunk said. However, if buy-in by the community was unsuccessful, Schrunk added, such areas would necessitate a permanent doubling or tripling of police. ${ }^{48}$

As McNamara and Earl spent much of that Wednesday jockeying over the protections necessary for Albina, Governor Tom McCall, responding to complaints from black residents concerning the behavior of Portland's police department, reaffirmed his defense of local law enforcement. McCall promised police protection to all Portland citizens under in all circumstances and asserted that violence of any kind would be punished. "Under no circumstances can we condone violence on the part of adults or youth, black or white," he stated. McCall specifically responded to requests by local activists that he take control of the city police. "I have read in the press that certain black militants have stated that they are going to meet with me with the request that I assume control in the city of Portland," McCall told the press. Acknowledging that his "Open Door Policy" was widely known throughout the state and often adhered to for the benefit 
of constituents, the governor declared he would not honor such a policy for a group of people who proposed violent solutions. "I do not intend to meet with them nor do anything to imply support of their position," he emphasized. Yet McCall did concede that police brutality might have taken place, that there may have been "isolated incidents where city police officers responded too vigorously to a situation," although he was careful to characterize such behavior as aberrations, rather than the norm. The police, in McCall's final assessment, had "exercised restraint and conducted themselves in proper fashion. $" 49$

While political leaders and police officials pledged to defend Albina property holders from violence, several local business owners signaled their intention to close their doors before moving out of the area or retiring. Others determined to protect their property from vandalism by arming themselves. "If they try to set fire to my place, I'm going to shoot a couple of them," stated a black Union Avenue store owner. Another resident spoke similarly. "I have my shotgun and it's loaded," he told the Oregonian. Such revelations, while impossible to verify by the police, prompted a stern reminder by Police Chief McNamara that while using a firearm to defend property in the event of such a conflict was legal, "Persons who use force will be hold severely accountable for any error in judgment." ${ }^{50}$ Should trouble in and around Albina on Wednesday night once again reach a level that the police could no longer contain, warned McNamara, a curfew would have to be imposed upon the entire city, to be enforced, if necessary, by the National Guard. ${ }^{51}$ 
As police, local officials, and Albina residents prepared for the potential for additional conflict on Wednesday night, it was apparent by early evening that their fears would not manifest. The likely result of cooler temperatures, the voluntary and early closing of many area businesses, including Lidio's, and a significant reduction in the number of patrolling police officers, had resulted in deserted streets and relative calm. Citizen committees, made up predominantly of black citizens of the Albina community, moreover, sought to suppress additional disturbances from breaking out. ${ }^{52}$

Despite this, black militants Kent Ford and Ralph Allen Stephenson were arrested on secret indictments charging them with felony assault in connection with the initial altercation at Lidio's Drive-In. Ford, who had initially gone to the police station to bail out a friend, was detained after officers recognized and searched him, finding ten long rifle shells in his pocket. ${ }^{53}$ Shortly after the arrests of Ford and Stephenson, officers in the same general area encountered rifle fire near a vacant lot while attempting to arrest two other black militants, including R.L. Anderson, on charges of conspiracy to commit arson. $^{54}$ Nearly three hours later, around 11:00 p.m., as a comparative peace had settled over the Albina area, around forty demonstrators, all of whom were white and of approximate college-age, protested the previous days' arrests by marching in and around both City Hall and the police station. Carrying signs supporting "Black America" and referring to the police as "pigs," the protestors carried out their action unbothered by the lone policeman watching them. ${ }^{55}$

The difficulties encountered by the police during the Anderson arrest, as well as the late-night protests at the police station, served as two minor aberrations in what had 
been the first violence-and-conflict free day out of the last five. In comparison to the previous evening, when nearly twenty fire alarms had been reported, only three fire calls were made between midnight and 7:00 a.m. Thursday. For the first time in a week, none of them originated from Albina. ${ }^{56}$

As Thursday came and went peacefully and without incident, the mood of the community seemed to shift from one of concern to reflection. Yet the police department, for the second time in two years, found itself as the prime target of many critics in the African American community. Local residents such as Jimmy “Bang Bang” Walker, who had been hospitalized as a result of injuries incurred during the disturbances, spoke bluntly on the issue of police brutality. While acknowledging that the entirety of Portland's police department could not be blamed for the racist behavior of a few, Walker asserted that it was imperative that Portland hire and retain officers who were not "bigoted, angry, or afraid." Walker conceded that local blacks could not, as some had begun to do, condone either the burning or looting of buildings that had taken place, stating that any individuals that had taken part in such behavior should face the consequences for their actions just as he expected the errant police officers to do. "Keeping cool is something that applies to the police as well as the black people," Walker stated, cautioning that police violence in which innocent civilians were injured without cause would further validate the arguments furthered by the most extreme elements of the community. ${ }^{57}$

\footnotetext{
1 “Black Panthers in Seattle," The Oregon-Advance Times, June 13, 1968, 11.
} 
${ }^{2}$ Department of Public Safety - Bureau of Police Intelligence Report, City of Portland, July 25, 1968, City of Portland, Schrunk papers, Stanley Parr Archival and Record Center, Portland City Archives, AF/167044, A 2011-002.

3 "Insurance Must Pay in 'Riot'," Oregon Journal, August 3, 1967, 3M 2J.

${ }^{4}$ Robert Olmos, "Blacks Claim Only Second-Rate Insurance Available to Albina," Oregonian, May 30, 1971, 4F.

5 Editorial, "Ghetto Tactics," The Clarion-Defender, October 17, 1968, 4.

${ }^{6}$ City Club of Portland, Report on Law Enforcement in the City of Portland, August 30, 1968, 138-139.

7 Sarah Mirk, "Talking with the Black Panthers," Portland Mercury, March 25, 2010, http://www.portlandmercury.com/portland/in-the-shadows/Content?oid=2379859, (accessed May 12, 2011).

${ }^{8}$ Martha Gies, “A Father's Story,” Portland Monthly, March 2005, 151.

9 "Police Battle Youths, Make Twelve Arrests," Oregonian, June 15, 1969, 3M 28.

${ }^{10}$ Ibid.

11 "Injured Officer Recalls Being Kicked on Ground," Oregonian, June 18, 1969, 4M 9.

12 “Arrest Try Triggers Disturbance," Oregon Journal, June 15, 1968, 1.

13 "Police, Gangs Clash; Businesses Damaged," Oregon Journal, June 15, 1969, 4J 5M.

${ }^{14}$ James Long. "'Trap for Arrest' Said Deliberate," Oregon Journal, June 16, 1969, 1.

15 “12 Injured in Disorder,” Oregonian, June 16, 1969, 22.

16 “Albina Violence Erupts,” Oregonian, June 16, 1969, 1.

17 “'Trap for Arrest' Said Deliberate," 1.

${ }^{18}$ Ibid.

19 “Albina Violence Erupts," 1.

${ }^{20}$ Ibid.

21 “'Trap for Arrest' Said Deliberate," 1.

22 "Police, Witness, Participants Offer Explanations for Albina Disorders," Oregonian, June 17, 1969, 4M 13; An interview with Ford in Polina Olsen's book Portland in the 1960s provides additional information and clarification regarding Ford's motivations for founding the Black Panther Party in Portland, as well as the programs and services the Party provided for their constituents.

23 Ibid.

24 “'Trap for Arrest' Said Deliberate," 1.

${ }^{25}$ Maurice Isserman, “1968 and All That: Radicals, Hippies, and SDS at Reed," Reed Magazine, Winter 2007, 29.

26 “Black Community Attacked," Willamette Bridge, Vol. 11 No. 12 (June 20 - July 3), 2.

${ }^{27}$ Ibid.

28 "Pantherrap," Willamette Bridge, Vol. 11 No. 12 (June 20 - July 3), 8.

29 "Police, Witness, Participants Offer Expanations for Albina Disorders," Oregonian, June 17, 1969, 4M 13.

${ }^{30}$ Ibid.

31 "Manager Charges Police Used Excessive Force; Officer Denies Claims," Oregonian, Wednesday, June 18, 1969, 1M 20.

${ }^{32}$ William Sanderson. “Albina Dwellers Charge Police With Beatings, Harassment,” Oregonian, June 17, 1969, 4M 13.

33 Ibid.

${ }^{34}$ Harold Hughes, “Mrs. Nixon, Julie Arrive For Projects Tour,” Oregonian, June 17, 1969, 1.

35 "Militants on Patrol," Oregon Journal, June 17, 1969, 4 J 4.

36 "Police on Guard After Albina Fuss," Oregonian, Jun 17, 1969, 1.

37 "Newsman Injured in Albina Flareup," Oregon Journal, June 17, 1961, 1.

38 "Schrunk Advocates Greater City Powers," Oregon Journal, June 17, 1969, 8J 3M.

${ }^{39}$ Ibid.

40 “Mayor Says Advice Given," Oregonian, June 18, 1969, 3M 21. 
41 “Woman's 'False Charges’ Upset McNamara,” Oregonian, June 18, 1969, 3M 21.

${ }^{42}$ Ibid.

${ }^{43}$ Ibid.

${ }^{44}$ Ibid.

45 "Five Blazes Hit Troubled Albina Area," Oregonian, June 18, 1969, 1.

46 "Calm Returns to Fire-Scarred Albina," Oregonian, June 19, 1969, 1.

47 "McNamara Triples Patrolmen in Area," Oregon Journal, June 18, 1969, 1.

48 Jack Ostergren, "Mayor Supports Aides on Albina," Oregon Journal, June 20, 1969, 4M J3.

49 "McCall Promises Citizen Protection," Oregonian, June 19, 1969, 1.

50 "Some Armed in NE Area," Oregonian, June 19, 1969, 3M 17.

51 "Calm Returns to Fire-Scarred Albina," 1.

52 "Cool Weather, Action By Citizens Help Restore Albina Area Peace," Oregonian, June 20, 1969, 1.

${ }^{53}$ G. Aichele and M.S. Hochstetler, "Officer's Report, 18 June 1969," Black Panther Information, Portland City Archives, Portland, Oregon, City of Portland, Stanley Parr Archival and Record Center, Riots (Archival) - Subject file (Police Historical/Archival Investigative Files: Bla - Bla), B/10438,

54 “Trouble Albina Calm, Quiet Again," Oregon Journal, June 19, 1969, 1.

${ }^{55}$ Ibid.

${ }^{56}$ Ibid.

${ }^{57}$ James Long, "Negro Editor Blames 'Few Bigoted Police'," Oregon Journal, June 19, 1969, 4M 6J. 


\section{Conclusion}

In the aftermath of the disturbance of 1969, representatives of the Albina community's clergy, while not in uniform agreement, used their positions to publicly reflect on the week's events. Reverend Mel Stead, the white pastor of Immaculate Heart Church, agreed with Jimmy Walker's assessment that the police had, on numerous occasions, overreacted in response to perceived threats. Others, such as Lee Stone, the African-American pastor at St. Philip's Episcopal Church, saw the uprisings as part of a larger context of changing race relations throughout the city and country. In a speech to an audience of 150 at the Downtown Kiwanis Club nearly a week after the start of the unrest, Stone acknowledged the presence of poorly trained and overly aggressive police officers but did not blame the recent racial strife on the "square pegs" that were found in every profession. Instead, he asserted that the displeasure and anger in the black community was a "manifestation of the search by Negroes for dignity and worth in their contributions to American life." Arguing that "festering sores" of powerlessness, hatred, and alienation often precipitated the outbreaks that occurred in the Albina district, Stone urged local Portland business leaders, both white and black, to acknowledge such realities and to deal fairly with black customers. ${ }^{1}$

Whatever the position of law enforcement officials, local government leaders, Albina residents, and members of the press, the primary blame for the Albina disturbances of 1969 could not be easily determined. While the police ultimately acknowledged specific instances of over-aggressive behavior during that week of conflict, no officer ever admitted to any overt or targeted surveillance of Portland's black 
activists. Although large numbers of African-American residents of Albina, as well as a few whites, were arrested for their actions and conduct over those five days of turmoil, moreover, no evidence ever surfaced that covert efforts of subversion were the primary goal for the local radicals at the center of the conflict. An Oregon Journal editorial, reflecting upon the disturbances a week later, spoke to this enigma. "Where justice lies in the recent violence between Portland police and relatively small groups of young Negroes is impossible fully to determine," the newspaper concluded. ${ }^{2}$

What had become obvious, however, was the rift that had developed between elements of Albina's youth and members of the black business community. In the wake of the disturbances, an unwritten law among many underwriters encouraged a refusal to renew or write new insurance policies for many segments of the Albina area. Such restrictions left many long-term residents and business owners displeased with the behavior of the area's younger blacks, particularly when they scared away real estate investment and perpetuated the deterioration of the area's housing market. Albina, according to one historian, was left to "predatory lenders, speculators, and absentee landlords" who profited from their own indifference to the rising dilapidation and abandonment of area homes. The emergence of white flight, as well as an epidemic of home abandonment throughout the neighborhood, stood as the backdrop for the community through the 1970 s and into the 1980 s. $^{3}$

Other community groups, once seen explicitly as advocates of the area youth they served, also began to find themselves encountering resistance. As the rhetoric and behavior of Portland's black radicals became increasingly more aggressive, the 
neighborhood's clergy, social workers, and area professionals, most of whom were committed to incremental approaches to racial equality, found themselves struggling to maintain credibility as intermediaries between black youth and city leaders. Labeled "Uncle Toms" if they spoke out in opposition or attempted to suppress the most radical statements and behavior of their peers, the groups took on a passivity that did not exist in earlier years. While submissiveness to the rhetorical extremism in the black community earned these groups additional legitimacy within Albina, such compliance eroded their standing with city leaders and government officials who had long seen such groups as credible allies in the fight for racial equality.

Members of Albina's clergy, often seen as too moderate and accommodating by younger parishioners, found themselves forced to assimilate to the changing culture of the community in order to remain relevant. Religious leaders who refused to modify their moderate positions on civil rights tended to find themselves marginalized and without influence. St. Mark's Baptist Church Reverand Edward Wilder spoke of this problem in a sermon in 1968 by suggesting that any church message on the struggle for equality that focused on approaching life in a positive manner was fruitless. It was with such an approach, Wilder concluded, that the church had lost its hold over young people. ${ }^{4}$ With the reorganization of the Albina Ministerial Alliance in 1970 under the leadership of Reverend John H. Jackson, however, the religious leaders of the area formally tied together concepts of religion and social action in a better effort to address both the economic and social inequalities within the neighborhood. 
Other groups and institutions in Portland such as the Society for a New Action Politics (SNAP), the Black Panthers, the Oregon Black Caucus, the Black Education Center, and the Fred Hampton Free Health Clinic directly challenged the gradualist rhetoric and approach of traditional civil rights organizations such as the Urban League and the National Association for the Advancement of Colored People (NAACP) and their moderate black constituencies. By 1972, moreover, the culture of Oregon's racial activism had changed so drastically that the NAACP, disgusted by the Caucus's decision to refuse white sympathizers admittance into the conference, refused to even send a delegate to the statewide meeting of the Oregon Black Caucus. ${ }^{5}$

At odds ideologically over both the ends and means of black activism, the fractured civil rights movement in the city found little consensus moving forward. Incensed by his own arrest by police during the 1969 disturbance, Kent Ford declared the official formation of the Portland chapter of the Black Panther Party while standing on the front steps of the police station following his release. While Northwest cities such as Portland and Seattle had seen an increase in activism by radical black organizations in the late 1960s, Ford's declaration marked a new chapter in Portland race relations. In the following decade, and despite low membership numbers, the Panthers worked to address many of the concerns that had served as the impetus for their formation. The organization established free breakfast programs for Albina's impoverished and economically disadvantaged children and worked to provide health and dental care for residents at no cost. Cognizant of an increasingly negative national perception of the Black Panther Party as purveyors of revolutionary violence by the early 1970s, Portland's 
chapter assumed a more moderate public stance when out in the community. "We never did openly display our weapons," stated Percy Hampton. "We didn't want anyone to perceive us as being out-of-control, gun-toting radicals."

Despite such efforts, however, the Panthers still failed to win over many of the community's moderate political and business leaders. The bombing of a N.E. Union Avenue McDonald's in 1970 was blamed on the Panthers despite a lack of evidence connecting the group to the explosion, while other assertions, aided by the local press, argued that the Panthers were involved in the extortion of community businesses and organizations that failed to donate money to their causes. While members of the BPP continually denied such accusations, quotes by Kent Ford in the fall of 1971 to the effect that anyone who attempted to "mess" with Panther programs would "meet their maker" contributed to the antagonism many moderate blacks and whites felt towards the group. ${ }^{7}$

This inflammation of rhetoric surrounding the struggle for black equality highlighted the schism between the perception of ideological purity among black radicals and the pragmatic social realities facing citizens and lawmakers. In Portland, the disturbances of 1967 and 1969, as well as the emergence of black radicals such as the Panthers in their wake, elucidated this contradiction between the ideological posturing necessary among these groups and the actual needs of the community that failed to be addressed as a result of such ideological extremism. While many of Portland's radicals saw the disturbances of the late-1960s as necessary to the growth of Black Nationalist ideology, the disturbances, and the subsequent epidemic of arson in the area in the following years, had a devastating economic and psychological impact on the district 
itself. Of the 200 businesses that had composed Albina's main commercial drag in 1967, nearly 30 percent, citing their own fears of safety and violence, had either closed or moved out of the area by October of 1970, leaving the neighborhood further depressed and exhibiting the look of a ghetto. Furthermore, the constant presence of fear among many residents was now directed at the neighborhood's most radical members, as opposed to the police. The elderly were "half out of their mind," stated one observer, while Albina citizens, both black and white, were "absolutely terrified" of the area's younger "troublemakers." cyclical nature of the problems faced by Albina's residents. While distrustful of a police force and city leadership that had often ignored their concerns, many residents also came to understand that the ideological hyperbole encompassed in the rhetorical posturing of groups such as the Black Panther Party delivered just as much pain as promise.

Regardless of the Panthers' controversial reputation, it was Kent Ford's nine-day trial in February 1970 that highlighted charges the group raised over police accountability in Portland. Arrested during the disturbances the previous June on charges of participating in a riot, Ford was ultimately acquitted. Determined, however, not to let the behavior of his accusers go unpunished, Ford's attorney filed a civil rights suit in federal court alleging that the plaintiff's rights had been violated when he was beaten and handcuffed by police on the night of his arrest. Six months after he had been acquitted of his riot charge, Ford was awarded a total of $\$ 6,000$ in damages, prompting the judge in the case to comment that it was time "the community realizes that the police are not free to inflict punishment." 
The post-disturbance landscape of Albina also brought changes to area education. The 1968 decision by Portland Public Schools (PPS) to combat neighborhood de facto segregation by busing Albina area students to suburban schools had seriously divided the community. The original strategy centered on the desire to desegregate community schools and suppress the underlying causes of future disturbances yet many AfricanAmerican parents grew to disdain placing their children in superior schools outside their neighborhood through the day, only to have them come back to the problems of the community each night. W.G. Hardy, a Portland native who lived through Portland's busing efforts in the late-60s, saw the event as traumatic for both whites and blacks. "The adults had no idea how traumatic it was for children to integrate into a culture to navigate through that, to develop relationships and then be torn apart," subsequently reminisced. ${ }^{10}$

Aware of such displeasure, PPS hired Superintendant Robert Blanchard who, in an effort to reverse the current efforts at desegregation, began the "Portland Schools for the Seventies" campaign. ${ }^{11}$ While encompassing a variety of approaches aimed at school desegregation including, but not limited to, the redrawing of attendance boundaries and the establishment of Early Childhood Education Centers (ECEC) aimed at attracting white students to the Albina neighborhood, it was Blanchard's attempt to accelerate Portland's busing efforts that caused the greatest controversy. By 1975, two-thirds of all of the students bused in Portland had been African-American. ${ }^{12}$ Moreover, nearly $22 \%$ $(2,346)$ of Portland's black population participated in the busing program in 1975 , while only 484 white students were involved during the same year. ${ }^{13}$ 
The inequalities between African-American students and their white counterparts built into the "Schools for the Seventies" campaign served as the catalyst for a series of subsequent educational reform efforts. In 1977, the Community Coalition for School Integration (CCSI), which included representatives from groups as diverse as the NAACP, the American Friends Service Committee (AFSC), and the Metropolitan Human Rights Commission (MHRC), thoroughly investigated previous efforts at public school desegregation in Portland. The coalition ultimately offered up thirty-five pages of recommendations, including a more equitable way to distribute busing among white and African-American students. ${ }^{14}$ Beginning in 1979, moreover, Portland's branch of the Black United Front (BUF) began an assault on the city school board to force change on the "Schools for the Seventies" plan. While advocating a variety of positions sympathetic to keeping Northeast Portland middle and high schools open, it was the BUF's targeting of busing for elimination that rallied supporters to their cause. Often confrontational, the power of the BUF was undeniable. When four school board members left their posts between 1978 and 1980, all four of their replacements were sympathetic to BUF causes. ${ }^{15}$

As the Black United Front continued to play a role in bringing more diversity to education in Portland, other efforts at fostering educational multiculturalism were taking center stage. Adopted in 1980 by PPS, an agreement known as the Comprehensive Desegregation Plan (CDP) stipulated that future school boards must create "an excellent multicultural/multiethnic education for all children." ${ }^{, 16}$ Out of this mandate grew a variety of efforts meant to remedy these perceived inequities. Meant to supplement and 
enhance existing curriculum, documents such as the African-American Baseline Essays became a part of PPS curriculum beginning in 1987 with the aim of creating a more multicultural and diverse learning experience. By 2001, Baseline Essays for Asian Americans had also become a part of the PPS curriculum. ${ }^{17}$

The adversarial relationship between much of Portland's African-American community and the police, while not entirely absent in the following decades, did not suffer from the same bitterness that had been directed towards the Albina police officers that had patrolled the neighborhood decades earlier. While Portland's police force, in its entirety, in the 1960s, could not fairly be described as racially bigoted, it is undeniable that large numbers of the force harbored racial prejudices that dictated their conduct in policing Albina. In fact, a 1966 survey of Portland's rank-and-file police officers determined that nearly 90 percent of all officers felt that the civil rights movement was had progressed too quickly, while just over half believed that racial equality was moving too rapidly. ${ }^{18}$

In September of 1969, having been denied legal equality by the city's law enforcement officials, a class action lawsuit on behalf of more than twenty thousand black Portlanders was brought to the U.S. District Court. Listing Mayor Terry Schrunk, Chief of Police Donald McNamara, the city council, and thirty-eight Portland police officers, the suit asked the court to end the institutionalized and organized discrimination of black residents by the police force in the form of harassment, illegal searches, and unjustified arrests. Stating that the police behavior forced the black community to "live in an atmosphere of fear and persecution," the complainants asked the judge to rule 
against the defendants to prohibit any future harassment. A final ruling, handed down in June of 1971 and referred to as the "Probasco Decree," named so because of the main complainant Robert Probasco, dictated that while the police bureau did not have to admit to any specific wrongdoing, it was prohibited from engaging in any of the alleged abusive behavior listed in the suit in any future interactions.

But while the Probasco Decree placed specific restraints physical and verbal abuse by police officers, the reforms were still challenged daily by individual officers acting independently and in violation of the law. While incidents in the ensuing decades involving prejudiced and racially intolerant police officers continued to undermine the police's ability to repair their relationship with the black community, the simmering hostilities that once existed between the groups has receded significantly. Furthermore, yearly efforts by the Portland Police Bureau to monitor minority arrest records, improve relationships with city youth, and participate in community outreach efforts reflect a selfawareness non-existent in the late 1960s.

In the decades following the Albina disturbances of the late-1960s, Portland still continued to struggle with the core economic issues that precipitated the initial conflict. Area real estate, which had been considered some of the worst in the city for nearly four decades, only recently became coveted property. Desired predominantly by white investors and homeowners, the area's new affluence has created a problem many never foresaw: many of the homes in the Albina neighborhood have become unaffordable to the area's African-Americans. Journalist Jacob Q. Sanders, writing reflectively on the neighborhood in a 2005 Portland Tribune article, wrote that nearly forty years after the 
disturbances, a Black resident of the newly gentrified Boise neighborhood claimed that “"a generation of black people' had grown up hearing the tale from their parents and grandparents of the "wicked White people who took away their neighborhoods.",19

Recent scholarship on this topic by Leanne Serbulo and Karen Gibson argues that Albina, as a result of years of residential segregation and racial isolation, began to view itself, much like other urban areas of the country, as an internal colony that had become "dependent on outsiders for political economic resources and subject to the authority of white-dominated institutions such as the school district, police, and welfare bureaucracy." Connecting the experiences of Portland's African-Americans to those of other northern cities experiencing heightened racial turmoil, the authors saw the behavior of the police as part of a "colonization process" that "ghettoized black citizens" and created an economic and political dependency that eroded the community. ${ }^{20}$

In support of their theory, Gibson and Serbulo make a compelling case. The authors cite a devastating conversation in which Mayor Terry Schrunk, confronted with requests by Albina residents to provide additional police officers to the neighborhood as a result of the increasing drug trade, casually asserts that the confinement of the drugs in Albina, to the exclusion of the rest of the city, did not merit greater law enforcement. The authors detail police surveillance efforts in the black community, cite statistics to demonstrate the paucity of black police officers and politicians in the city, and bring to light the efforts of FBI agents to infiltrate and discredit individuals associated with black nationalist movements. Moreover, Gibson and Serbulo provide numerous accounts of sabotage by members of the police department when they were directed to implement 
reforms. ${ }^{21}$ Such actions, as embodied by the police bureau, can only be seen as part of an effort to protect a racial status quo and stifle racial equality. Consequently, many of Albina's black youths, frustrated by dwindling economic opportunities, inequalities in education, and frequent police harassment, and motivated by the emergence of Black Nationalist rhetoric, viewed the police as the symbol of racial oppression.

But while the actions and behavior of city politicians and law enforcement officials cited in Gibson and Serbulow's article indicate the prevalence of systematic and widespread racial discrimination, their argument that Albina fits the characteristics of the colonial model can be disputed. While the assertion by the authors that "black citizens saw police officers as representatives of a state that had delegated 'the legitimate use of violence to police authority' in the interest of subordination," is accurate in many respects, it is also true that a monolithic view of the police among African-Americans did not exist. ${ }^{22}$ As argued in earlier chapters of this thesis, many older Albina residents, displeased with the increase in the amount of vandalism and violence in the neighborhood, saw the police as allies, as opposed to oppressors. Having established their families in the neighborhood over previous decades, many older residents saw the police as necessary to protect their homes and businesses in an increasingly dangerous neighborhood.

Gibson and Serbulo supplement their colonial model by asserting that the "colonial framework challenged liberalism because it argued for the redistribution of power and institutional control, rather than assimilation and integration into existing institutions through practices such as school busing and affirmative action." ${ }^{23}$ While civil 
rights activists in Portland did work to create levers of institutional change to redefine fundamental aspects of society (the commitment of the Black Panthers to providing free social and medical services to the underprivileged; and the efforts of the Black United Front to reshape public education in the early-1980s), they also worked incrementally on issues of employment, education, and police-community relations in ways that can only be described as integrationist. Remedies such as busing, along with numerous other efforts, were often the assimilationist tactics used to try to bring about the desired goal of greater racial equality. Rather than immediately attempting to seize control of institutions, as is stated in the colonial framework, most advocates of racial equality simply sought to gain improvements in areas of employment and education. Not only had racial integration been the goal for most Portland African-Americans, but it had stood as the foundation of the civil rights strategy of local organizations such as the Urban League and the NAACP since their inception.

Statistically speaking, the modern Albina district no longer possesses a monopoly on Portland's African-American population. Between the years 2000 and 2010, nearly 10,000 African-Americans, pushed out of the area as a result of gentrification, left the city for cheaper housing on the eastern edges of Portland. ${ }^{24}$ "We anticipated gentrification and welcomed it to a degree," says Carl Talton, cofounder of the North/Northeast Economic Development Alliance. "What we didn't anticipate was that we wouldn't be able to manage it and that it would just run away." ${ }^{25}$ While the number of African-Americans decreased in the city's inner east side between 2000 and 2010, the inner north and northeast areas experienced the greatest racial change with nearly 7,700 
African-Americans moving out. ${ }^{26}$ In this same area of time, neighborhood tracts east of $82^{\text {nd }}$ street saw an increase in nearly 9,300 black residents, most of whom had migrated from the inner east side of the city. ${ }^{27}$ While still home to the greatest concentration of the city's African-Americans, which now make up nearly 7 percent of the city's total population, young and affluent whites have gentrified this section of Albina, creating newer and more expensive real estate. ${ }^{28}$ "The exodus from the central city causes me great concern; it is alarming," stated Portland Mayor Sam Adams in 2011. "Whether you are a Portlander of color or a white Portlander, you should care about the fact that we offer such limited access to equal opportunities." 29 The mayor's statement, nearly forty years after disturbances erupted in Albina, reflected the modern incarnation of a sentiment first expressed by a black resident of the neighborhood in 1967:

"Albina might have been just a section of the city with no name," the resident asserted. "But when Negro families start moving in - it's 'Albina'.,"30

\footnotetext{
1 "Black Troubles Laid to Search for Worth," Oregon Journal, June 18, 1969, 3M $10 \mathrm{~J}$.

${ }^{2}$ Editorial, "Law and Order in Albina," Oregon Journal, June 18, 1969, 3M 16J.

${ }^{3}$ Karen Gibson, "Bleeding Albina: A History of Community Disinvestment, 1940-2000," Transforming Anthropology 15 (2007), 3.

${ }^{4}$ Jane Van Cleve, "The Negro in our Community," Sunday Oregonian Magazine, January 21, 1968, 130.

${ }^{5}$ Steven Reed Johnson, "The Evolution of Civic Evolution in the Albina Neighborhood," http://www.google.com/url?sa=t\&rct=j\&q=\&esrc=s\&source=web\&cd=2\&ved=0CDQQFjAB\&url=http\%3 A\%2F\%2Fstevenreedjohnson.com\%2Fstevenreedjohnson\%2FCivicPdxAlbina_files\%2FAlbina\%2520Neig hborhood.pdf\&ei=pdEzUaizFIOgiALKtoHYCw\&usg=AFQjCNFMsKH7WW51IMgi5jzwRrfQE65wYw\& bvm=bv.43148975,d.cGE, (accessed April 2, 2013), 21.

${ }^{6}$ Jules Boykoff and Martha Gies, "We're Going to Defend Ourselves: The Portland Chapter of the Black Panther Party and the Local Media Response," Oregon Historical Quarterly 111 (Spring 2010), 286.

${ }^{7}$ Bill Keller, "Breakfast, Clinic Programs Belie Militant Panther Image," Oregonian, November 12, 1971, 23.

${ }^{8}$ Judson Randall, “Arson Held Primary Cause of Dwindling Economy," Oregonian, October 18, 1970, 38.

9 John Painter Jr., "Jury Acquits Panther Tried on Riot Charge," Oregonian, February 14, 1970, 1.; "Judge Awards \$6,000 Judgment to Black Panther from Police," Oregonian, August 28, 1970, 41.
} 
${ }^{10}$ Reverend W.G. Hardy interviewed by Jason Wilde, Portland, Oregon, November 19, 2008, 8-9, Portland State University Library (Archival) - PDX Civil Rights Project collection.

${ }^{11}$ Johnson and Williams, "Desegregation and Multiculturalism in the Portland Public Schools," 13.

${ }^{12}$ Ibid., 13-14.

${ }^{13}$ Ibid., 14.

${ }^{14}$ Christopher H. Riser, "Desegregation and Curricular Reform: The Context of Portland, Oregon's African American Baseline Essays and the Struggle to Desegregate Hearts and Minds," Bachelor's of Arts with Honors in History Thesis, Portland State University 2012, 35.

${ }^{15}$ Johnson and Williams, "Desegregation and Multiculturalism in the Portland Public Schools," 18.

${ }^{16}$ Ibid., 19.

${ }^{17}$ Riser, "Desegregation and Curricular Reform," 45.

${ }^{18}$ Kenneth Robert Gervais, "The Portland Police Officer" (Ph. D. diss., Claremont Graduate School, 1968), 188.

${ }^{19}$ Jacob Q. Sanders, "Rethinking Portland: One Neighborhood's Story," Portland Tribune, November 11, $2005,23$.

${ }^{20}$ Karen J. Gibson and Leanne C. Serbulo, "Black and Blue: Police-Community Relations in Portland's Albina District, 1964-1985," Oregon Historical Quarterly 114:1 (Spring 2013): 8-9.

${ }^{21}$ Ibid., 6, 12-15.

${ }^{22}$ Ibid., 31; Robert Blauner, "Internal Colonialism and Ghetto Revolt," Social Problems 16:4 (1969): 393$408,115$.

${ }^{23}$ Gibson and Serbulow, "Black and Blue: Police-Community Relations in Portland's Albina District, 1964-1985," 9.

${ }^{24}$ Nikole Hannah-Jones, “In Portland's Heart, 2010 Census Shows Diversity Dwindling,” Oregonian, April 30, 2011, < http://www.oregonlive.com/pacific-northwestnews/index.ssf/2011/04/in_portlands_heart_diversity_dwindles.html>, (accessed April 2, 2013).

${ }^{25}$ Randy Gregg, "Black in Portland," Portland Monthly, February 12, 2002, http://www.portlandmonthlymag.com/news-and-profiles/history/articles/black-in-portland-march-2012, (accessed April 2, 2013).

${ }^{26}$ Hannah-Jones, "In Portland's Heart, 2010 Census Shows Diversity Dwindling."

${ }^{27}$ Gregg, "Black in Portland."

${ }^{28}$ William Yardley, "Racial Shift in a Progressive City Spurs Talks," New York Times, May 29, 2008, http://www.nytimes.com/2008/05/29/us/29portland.html?pagewanted=all\&_r=0, (accessed April 2, 2013).

${ }^{29}$ Hannah-Jones, "In Portland's Heart, 2010 Census Shows Diversity Dwindling."

30 "Despite Overpowering Urban Handicaps, Many Albina Residents Fight For Survival," Oregonian, October 8, 1967, 6F. 


\section{Sources Consulted}

\section{PRIMARY SOURCES}

A. Correspondence, Documents, Directories, and Reports

C-CAP Pamphlet, Oregon Historical Society Archives, City of Portland, Albina (Vertical File 1 of 3), 1967.

City Club of Portland. Problems of Racial Justice in Portland, Richard W. Nahstoll, Chair,1968, 5.

. Report on Law Enforcement in the City of Portland, 1968, 138-

139.

City of Portland. Stanley Parr Archives and Research Center. Black Panther Information. Officer's Report, 18 June 1969. G. Aichele and M.S. Hochstetler. B/10438.

125110.

- City Auditor. Ordinance

. City Code for the

Reporting of Civil Disorders, 1967.

. Department of Public

Safety. Bureau of Police Intelligence Report, 25 July 1968.

. Human Relations

Commission of the City of Portland. 1967 Annual Report, 1967.

. A Description of Inter-Group Relations

Problems in Portland and Challenges for 1968, 1968.

Discriminatory Employment Practices, 1968.

Memorandum. Non-

Hall Meeting at Buckman School, 11 July 1968.

Minutes of Little City 
Hall Meeting at Buckman School, 7 October, 1968.

Schrunk, Terry M., papers, Stanley Parr Archives and Research Center, City of Portland, AF/167044, A 2011-002. "Bibiana Maher to Terry Schrunk," 1 August 1967.

. "Dd Loretta Wooster to Terry Schrunk," 28 July 1967.

. 'Clifford Daniels, letter to Terry Schrunk, August 1, 1967."

. "E.H.B. to Terry Schrunk,” 28 July 1967.

. “H.D. Smith to Terry Schrunk," 1 August 1967.

. “H. Eugene Kirchner to Terry Schrunk,” 6 August 1967.

. “J.D. Millner to Terry Schrunk,” 31 July 1967.

. "Katharine T. Noyes to Terry Schrunk," 31 July 1967.

. “KPOJ Editorial staff to Terry Schrunk," 3 August 1967.

. "Letter to Terry Schrunk," (Anonymous) 4 August 1967.

1967.

. "Lorena Schultz, letter to Terry Schrunk," 1 August

. "Margaret Luyben, letter to Terry Schrunk," 1 August

1967.

. "Nellie Mitchell, letter to Terry Schrunk," 22 October,

1967.

. "Richard Mason, letter to Terry Schrunk, 2 February

1968.

- "Terry Schrunk, to Boston University student Donna

Gables,” 28 December 1967.

August 1967.

. “Terry Schrunk, to Congressional Quarterly Service," 11 
"Terry Schrunk to Oregon Congressional Delegation,” 30

July 1967.

Urban League. 1967 Annual Convention: People v. the City: Opportunity and Challenge, 1967.

Urban League of Portland Annual Report (1966-1967). Education and Youth Incentives Projections for 1967. Urban League of Portland. 1966.

U.S. Census of Population and Housing, 1960: Summary Population and Housing Characteristics: Oregon. Washington: Government Printing Office, 1960.

\section{B. Periodical and Newspaper Articles}

“4 ‘Rail Rider’ Get Jail Terms.” Oregon Journal, 1 August 1967, 1.

“12 Injured in Disorder.” Oregonian, 16 June 1969, 22.

“13 Fires Ignited By Gangs.” Oregon Journal, 1 August 1967, 1.

“Albina Violence Erupts." Oregonian, 16 June 1969, 1.

“All Portland Schools to Open on Monday." Oregonian, 8 April 1968, 1.

“All Schools Here Set Late Start Tuesday.” Oregon Journal, 8 April 1968, 7.

“Arrest Try Triggers Disturbance.” Oregon Journal, 15 June 1968, 1.

“Black Community Attacked.” Willamette Bridge, 20 June - 3 July, 21969.

"Black Panthers in Seattle." The Oregon-Advance Times, 13 June 1968, 11.

““Black Summer' Progressing.” Oregon Advance-Times, 13 June 1968, 11.

"Black Troubles Laid to Search for Worth." Oregon Journal, 18 June 1969, 3M 10J.

"Butler Airs Views on City Club Report." Oregon Advance-Times, 20 June 1968, 1.

"Calm Returns to Fire-Scarred Albina." Oregonian, 19 June 1969, 1.

"Chance Open for Negroes to Get Fire or Police Jobs." Oregon Advance-Times, 1 February 1968, 3. 
“Clerics Tell Mayor to Aid Negroes Here.” Oregon Journal, 6 April 1968, 1.

"Cool Weather, Action By Citizens Help Restore Albina Area Peace." Oregonian, 20 June $1969,1$.

"Despite Overpowering Urban Handicaps, Many Albina Residents Fight For Survival," Oregonian, 8 October 1967, 6F.

“Employed Youth Shun Trouble.” Oregon Journal, 3 August 1967, 5M 6J.

"FBI Hunts Agitators of Turmoil." Oregon Journal, 1 August 1 1967, 1.

“Fire Clears School.” Oregon Journal, 5 April 1968, 5M J3.

"Five Blazes Hit Troubled Albina Area." Oregonian, 18 June 1969, 1.

“Gangs Burn Stores; Youth Shot; 6 Hurt.” Oregon Journal, 31 July 1967, 1.

“Hoover Tells Panel No Conspiracy Seen.” Oregonian, 2 August 1967, 6M 15.

"Injured Officer Recalls Being Kicked on Ground.” Oregonian, 18 June 1969, 4M 9.

"Insurance Must Pay in 'Riot'." Oregon Journal, 3 August 1967, 3M 2J.

“Jeff Calls 2-Day Halt.” Oregonian, 7 April 1968, 1.

“Jeff High Shut Down By Unrest.” Oregonian, 7 April 1968, 1.

“Jefferson Classes Out Early.” Oregon Journal, 6 April 1968, 5M J3.

“Jefferson to Close as King Tribute.” Oregonian, 7 April 1968, 3M 19.

"Jefferson Due Extra Policemen." Oregon Journal, 8 April 1968, 4M J3.

“Judge Awards \$6,000 Judgment to Black Panther from Police." Oregonian, 28 August $1970,41$.

“King Death Termed 'Ironic’ by McCall.” Oregon Journal, 5 April 1968, 5M 4J.

"Manager Charges Police Used Excessive Force; Officer Denies Claims." Oregonian, 18 June 1969, 1M 20.

"Mayor Says Advice Given." Oregonian 18 June 1969, 3M 21.

“McCall Concerned By Racial Rioting,” Oregon Journal, 29 July 1967, 5M 5J. 
“McCall Promises Citizen Protection." Oregonian, 19 June 1969, 1.

"McNamara Triples Patrolmen in Area." Oregon Journal, 18 June 1969, 1.

"Militants on Patrol." Oregon Journal, 17 June 1969, $4 \mathrm{~J} 4$.

"Negro Former FBI Undercover Agent Blames Communists For Racial Strife." Oregonian, 2 August 1967, 4M 17.

"Negro Gang Assaults 15 Year Park Veteran.” Oregonian, 1 August 1967, 6M 16.

“Newsman Injured in Albina Flareup.” Oregon Journal, 17 June 1967, 1.

"Pantherrap." Willamette Bridge, 20 June - 3 July, 1969.

"Parks Chief Ivancie Talks to Albina People, Declares Door Open for Recreation Ideas." Oregonian, 3 August 1967, 5M 13.

“Police Battle Youths, Make Twelve Arrests." Oregonian, 15 June 1969, 3M 28.

“Police, Gangs Clash; Businesses Damaged.” Oregon Journal 15 June 1969, 4J 5M.

"Police on Guard After Albina Fuss." Oregonian, 17 June 1969, 1.

"Police Hire Ten Black Teenagers." Oregon Advance-Times, 8 August 1968, 1.

"Police, Witness, Participants Offer Explanations for Albina Disorders." Oregonian, 17 June 1969, 4M 13.

“Race Woe Occupies Board.” Oregon Journal, 9 April 1968, 1M.

“Race Riot Here Held Doubtful.” Oregon Journal, 25 July 1967, 5M 12J.

“Racial Justice Report Adopted By City Club.” Oregon Journal, 15 June 1968, 5M J3.

"Ramparts Editor Main Attraction.” Oregon Journal, 31 July 1967, 5M 4J.

“Riots Hit 40 Cities; 20 Dead.” Oregon Journal, 6 April 1968, 1.

"Schrunk Advocates Greater City Powers.” Oregon Journal, 17 June 1969, 8J 3M.

“Some Armed in NE Area." Oregonian, 19 June 1969, 3M 17.

“Trouble Albina Calm, Quiet Again.” Oregon Journal, 19 June 1969, 1. 
"Victims Side of Club ... In a Planned Police Riot." Willamette Bridge, 27 June - 3 July $1969,8$.

“Woman’s ‘False Charges’ Upset McNamara.” Oregonian, 18 June 1969, 3M 21.

"Youth Charged with Offenses." Oregonian, 25 May 1969, 14.

Berry, Jack. "Assassination Saddens Portland Leaders; Fuel For Advocates of Violence Feared." Oregonian, 5 April 1968, 4M 14.

Brown, Jr., Colden. “Rapping About Albina.” Vanguard, 27 September 27 1967, 10.

Collins, Bill. "Saddened Albina Residents Angry at Rioters." Oregon Journal 31 July 1967, 5 J5.

Editorial. Oregon Journal, 21 July 1967, 3M 14J.

. "Ghetto Tactics." The Clarion-Defender, 17 October 1968, 4.

. "Law and Order in Albina." Oregon Journal, 18 June 1969, 3M 16J.

. "Portland's Turn on the Riot Scene." Oregon Journal, 1 August 1967, 17.

. "Problem Exists Here, Too." Oregon Advance-Times, 7 March 1968, 3.

Federman, Stan. "Albina Adults Deplore Strife, Help Police Rout Gangs.” Oregonian, 31 July 1967, 6M 14.

2 August 1967, 6M 15.

. "Police Move to Put Down Disturbances." Oregonian, 31 July 1967, 1.

Floyd, Richard. “Metropolitan Steering Group Explore Unrest Cause.” Oregonian, 1 August 1967, 6M 16.

Friedman, Ralph. "Sudden Mood Change Frightening At Scene of Riot." Oregon Journal, 31 July 1967, J5.

Guernsey, John. "Rowdies Dispersed at Park” Oregonian, 1 August 1967, 1.

Hanna, Charlie. "Need For More Jobs For Negro Youths Cited By Officials Of Urban League." Oregonian, 1 August 1967, 6M 16. 
Hill, James. "Officers Seal Off District in Albina to Curb Disorders By Teen Gangs." Oregonian, 31 July 1967, 6M 14.

Hughes, Harold. “McCall Eyes Strife Scene.” Oregonian, 31 July 1967, 1. $1969,1$. "Mrs. Nixon, Julie Arrive For Projects Tour." Oregonian, 17 June

Jumper, Ken. "Chicago Riot Issues Studied by Schrunk." Oregon Journal, 15 June 1968, $3 \mathrm{M} 2 \mathrm{~J}$.

Keller, Bill. "Breakfast, Clinic Programs Belie Militant Panther Image.” Oregonian, 12 November 1971, 23.

Lawson, Rob. “Jeff Problems.” Oregon Advance-Times, 29 February 1968, 9.

Long, James. "Negro Editor Blames 'Few Bigoted Police'.” Oregon Journal, 19 June 1969, 4M 6J.

Long. James. “'Trap for Arrest' Said Deliberate.” Oregon Journal, 16 June 1969, 1.

Macnab, Gordon. "Portland's Teen-age Negroes Refuse to Bear Frustrations of Parents." Oregonian, 1 June 1967, 4M 15.

Mershon, Andrew. "Partial Blame Placed on School Levy Loss." Oregonian, 1 August 1967, 6M 16.

Olds, Bob. "Police Put in 'Tough Night,' Don't Expect More Violence." Oregon Journal, 31 July 1967, J5.

Olmos, Robert. "Blacks Claim Only Second-Rate Insurance Available to Albina." Oregonian, 30 May 1971, 4F.

."Negro Leaders Declare Albina Refuses to Accept Black Power Theory." Oregonian, 1 August, 1967, 6M 16.

1. . "Peace Returns After 2 Nights of Disorder." Oregonian, 2 August 1967, "Portland Negro Leader Claims 'Outsiders' Sparked Albina Youths' Disorder." Oregonian, 31 July 1967, 8M 17.

Ostergren, Jack. "City Commissioners Dispute Findings of City Club Report." Oregon Journal, 13 June 1968, 5M J3. 
$4 \mathrm{M} \mathrm{J} 3$.

“Mayor Supports Aides on Albina." Oregon Journal, 20 June 1969,

Painter Jr., John. “Jury Acquits Panther Tried on Riot Charge.” Oregonian, 14 February 1970, 1.

$2 \mathrm{M} 68$.

“Study Shows Portland Could Explode." Oregonian, 28 January 1968,

Pickett, Nelson. "King’s Death Considered Blow to Nonviolent Movement." Oregon Journal, 5 April 1968, 5M 4J.

Porter, Doug. "Discontent of Portland's Negroes Laid to Unemployment." Oregon Journal, 1 August 1967, J7.

Randall, Judson. "Arson Held Primary Cause of Dwindling Economy." Oregonian, 18 October 1970, 38.

Sanderson, William. "Albina Dwellers Charge Police With Beatings, Harassment." Oregonian, 17 June 1969, 4M 13.

Oregonian, 6 August 1968, 6M 4J.

. 'Negro Youths Fear Mayor 'Missed Message' of City Hall

Discussion." Oregonian, 2 August 1967, 6M 15.

Smith, Judd. "Negro Youths Trace Albina Unrest to Racial Warfare in Other Cities." Oregonian, 1 August 1 1967, 6M 17.

Spence, Morton. "Militants Here Vow to Advance Cause.” Oregon Journal, 5 April 1968, 5M J3. 1968, 4J 4M.

Thompson, Wayne. "Race Report Greeted By Enthusiasm, Hope, Plus Skepticism on Pertinence to Portland." Oregonian, 3 March 1968, 4M 29.

Tugman, Peter. "Six Talkative Negro Prisoners Voice Resentment of City Police." Oregonian, 2 August 1967, 6M 15.

Van Cleve, Jane. "The Negro in our Community." Sunday Oregonian Magazine, 21 January 1968, 130. 


\section{Journal and Magazine Articles}

Blauner, Robert. "Internal Colonialism and Ghetto Revolt," Social Problems 16 (1969), $393-408,115$.

Sorenson, Annemette, and Karl Taeuber, "Indexes of Racial Residential Segregation for 109 Cities in the United States, 1940-1970," Sociological Focus 8 (1970): $125-142$.

D. Academic Theses

Gervais, Kenneth R. “The Portland Police Officer.” Ph. D. dissertation, Claremont Graduate School, 1968. 


\section{SECONDARY SOURCES}

\section{A. Periodical and Newspaper Articles}

Frank, Ryan. “Potter on Riots, Redevelopments." Oregonian, 15 June 2006, 13.

Hannah-Jones, Nikole. "In Portland's Heart, 2010 Census Shows Diversity Dwindling." Oregonian, 30 April 2011, < http://www.oregonlive.com/pacific-northwestnews/index.ssf/2011/04/in_portlands_heart_diversity_dwindles.html>.

Mirk, Sarah. "Talking with the Black Panthers." Portland Mercury, 25 March 2010, http://www.portlandmercury.com/portland/in-the-shadows/Content?oid=2379859.

Sanders, Jacob Q. "Rethinking Portland: One Neighborhood's Story.” Portland Tribune, 11 November 11 2005, 23.

Yardley, William. "Racial Shift in a Progressive City Spurs Talks." New York Times, 29 May 2008, http://www.nytimes.com/2008/05/29/us/29portland.html?page wanted $=$ all \&_r $=0$.

\section{B. Books/Memoirs}

Churchill, Ward, and Jim VanDerWall. The COINTELPRO Papers: Documents from the FBI's Secret Wars Against Domestic Dissent. Boston, MA: South End Press, 1990.

Denton, Nancy J., and Douglas Massey. American Apartheid: Segregation and the Making of the Underclass. Cambridge, MA: Harvard University Press, 1993.

Dietsche, Robert. Jumptown: the Golden Years of Portland Jazz, 1942-1957. Corvallis, OR: Oregon State University Press, 2005.

Gordly, Avel Louise, and Patricia Ann Schechter. Remembering the Power of Words: The Life of an Oregon Activist, Legislator, and Community Leader. Corvallis, OR: Oregon State University Press, 2011.

Joseph, Peniel. Waiting 'Til the Midnight Hour: A Narrative History of Black Power in America. New York, NY: Owl Books, 2006.

Newton, Huey. War Against the Panthers: A Study of Repression in America. Writers and Readers, 2000. 
Olsen, Polina. Portland in the 1960s: Stories from the Counterculture. The History Press, 2012.

Portland Bureau of Planning. History of Portland's African-American Community (1805-Present). Portland, OR, 1993.

Roos, Roy E. The History of Albina: Including Eliot, Boise, King, Humboldt, and Piedmont Neighborhoods. Portland, OR, 2008.

\section{Journal and Magazine Articles}

Boykoff, Jules, and Martha Gies. "We're Going to Defend Ourselves: The Portland Chapter of the Black Panther Party and the Local Media Response," Oregon Historical Quarterly 111 (2010), 286.

Gibson, Karen J. "Bleeding Albina: A History of Community Disinvestment, 19402000," Transforming Anthropology 15 (2007): 4-22.

Gibson, Karen J., and Leanne C. Serbulo. "Black and Blue: Police-Community Relations in Portland's Albina District, 1964-1985," Oregon Historical Quarterly 114 (2013): 6-37.

Gies, Martha. “A Father’s Story,” Portland Monthly, March 2005, 151.

Gregg, Randy. "Black in Portland" Portland Monthly, 12 February 2002, http://www.portlandmonthlymag.com/news-and-profiles/history/articles/black-inportland-march-2012.

Maurice Isserman. "1968 and All That: Radicals, Hippies, and SDS at Reed," Reed Magazine (2007): 29.

Johnson, Ethan, and Felicia Williams. "Desegregation and Multiculturalism in the Portland Public Schools," Oregon Historical Quarterly 111 (2010): 6-37.

Johnson, Steven Reed. "The Evolution of Civic Activism in the Albina Community," http://www.google.com/url?sa=t\&rct=j\&q=\&esrc=s\&source=web\&cd=2\&ved $=0$ CDQQFjAB\&url=http\%3A\%2F\%2Fstevenreedjohnson.com\%2Fstevenreedjohns on\%2FCivicPdxAlbina_files\%2FAlbina\%2520Neighborhood.pdf\&ei=pdEzUaizF IOgiALKtoHYCw\&usg=AFQjCNFMsKH7WW51IMgi5jzwRrfQE65wYw\&bvm $=$ bv.43148975, d.cGE. 
D. Video

Tuttle, Jon, John Lindsay, Steve Gosson, Michael Bard, and Glenn Holstrom. Local Color. Portland, OR: Oregon Public Broadcasting, 1999.

\section{E. Oral Histories}

Oregon Historical Society, Oral Interview with E. Shelton Hill (1976), SR 0267.

Portland State University, PDX Civil Rights Project collection, Oral Interview with Reverend W.G. Hardy (2008).

\section{F. Academic Theses}

Buhler, Julie Lorana. "The Civil Rights Movement in Portland, Oregon, 1955-1968." Honor's thesis, University of Oregon, 1983.

Jackson, James Tucker. "Culture War: The Battle for Portland's Laur Hill Neighborhood, 1968.” Master's thesis, Portland State University, 2007.

Riser, Christopher H. "Desegregation and Curricular Reform: The Context of Portland, Oregon's African American Baseline Essays and the Struggle to Desegregate Hearts and Minds." B.A. Honors Thesis, Portland State University, 2012. 
Appendix A: Map of the Albina Neighborhood (1970)

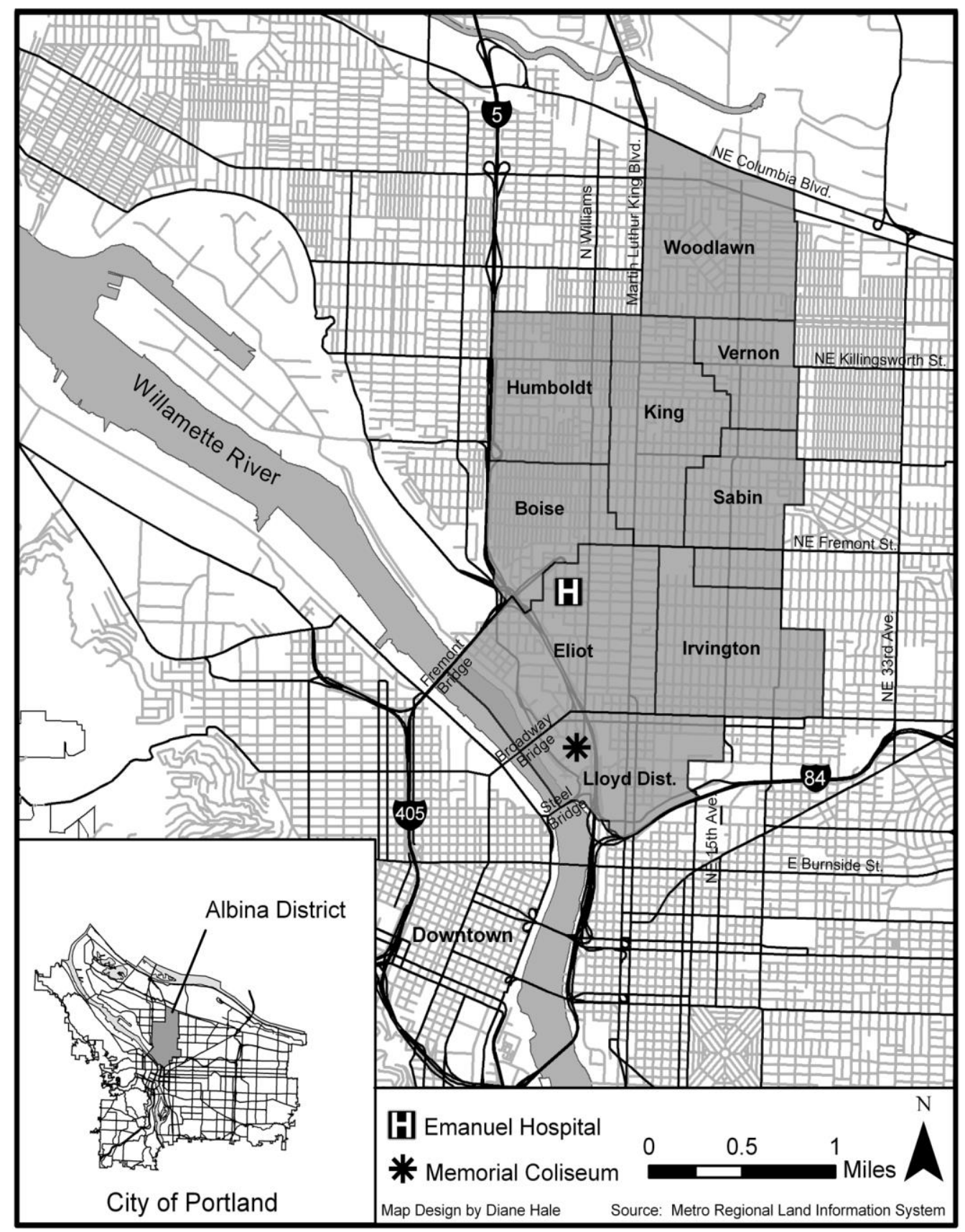

Portland, Oregon's Albina District neighborhoods 